\title{
Algunas consideraciones sobre las ciudades romanas del territorio vascón y su proceso de monumentalización
}

\author{
Some considerations on Roman cities in the Vascones' territory \\ and its monumentalization process.
}

\author{
JaVier ANDREU PINTAdo \\ UNED
}

\begin{abstract}
RESUMEN
ABSTRACT

Sin lugar a dudas, la instalación de la ciuitas - con sus procesos progresivos de consolidación, mejora estatutaria y monumentalización-constituye uno de los elementos clave en el proceso de integración de los indígenas en la órbita administrativa y política de Roma. La documentación arqueológica y epigráfica nos permite, muchas veces, reconstruir los ritmos de monumentalización de las ciuitates de las provincias occidentales del Imperio comprendiendo así mejor las variables que motivaron este tipo de procesos y su relación con la coyuntura histórica, política y jurídica de los asentamientos y de su entorno. En el presente trabajo se analizan - a partir de las tres líneas documentales disponibles:

la de los datos arqueológicos, la de la documentación epigráfica y aun la de la estatuaria- los ritmos de monumentalización que pueden constatarse para las ciuitates atribuidas a la etnia histórica de los Vascones y que, fundamentalmente, conocemos por Plinio

y por Ptolomeo. Se abordan también algunas cuestiones preliminares sobre la identificación de ciuitates de localización aun ignota y sobre las características de la documentación relativa al asunto.

There is no doubt that ciuitas' foundation -with its progressive dymensions of consolidation, juridical status development and monumentalization - is one of me most important processses related with romanization and with indigenous population's integration in Rome's political and administrative organization. In some many times both the archaeological documentation and the epigraphic one lead us to rebuild the ciuitates's monumentalization's parameters and rhythms in the western provinces of the Roman Empire. Anyway, from this point of view we can also study the motivations related with such those important processes and the relationship between those and the historical, political and juridical enviroment surrounding the settlements and its territory. In this paper -from the three available documental lines: archaeological data, epigraphic documentation and the statuary - it will be analyze the monumentalization and urban development rythms that can be described for the ciuitates of the historical ethnos of the Vascones about we are informed, mainly, by Pliny and Ptolomeus. Also we are going to approach in the geographical identification of some of those ciuitates,
\end{abstract}


PALABRAS CLAVE:

Hispania, Vascones, municipalización, urbanización, Epigrafía, documentación arqueológica, monumentalización, desarrollo urbano. still unknown, and in the available documentation characters.

\author{
KEYWORDS: \\ Hispania, Vascones, municipalization, \\ urbanization, Epigraphy, archaeological \\ sources, monumentalization, urban \\ development.
}

0 *

Abordar un tema como el que da título al presente trabajo puede parecer, cuando menos, pretencioso. No en vano, prácticamente ninguno de los elementos a que se alude en el encabezamiento del mismo está exento de controversias. Por un lado, aunque sí disponemos de una instantánea -fechada en torno al $135 \mathrm{~d}$. C.- - del territorio vascón —la que nos aporta Ptolomeo en su Geographiké Hyphégesis 1 - sigue abierta la cuestión del modo cómo éste acabó por configurarse en las fronteras que pueden desprenderse de la nómina de póleis que atribuye al mismo el geógrafo alejandrino². Por otra parte, y porque sus obras persiguieron obje-

\footnotetext{
"El presente trabajo constituye parte de la conferencia que bajo el título «La ciudad romana en el ámbito vascón» fue pronunciada por el autor el lunes 8 de mayo de 2006 en la Sesión de Clausura del ciclo de conferencias La Ciudad en la Antigüedad: Aproximación a la Vida Urbana en el Occidente Mediterráneo en la Antigüedad Clásica organizado por la Oficina de Extensión Universitaria del Centro Asociado de la UNED en Tudela (Navarra) y que tuvo lugar entre Marzo y Mayo del citado año. Queremos dejar

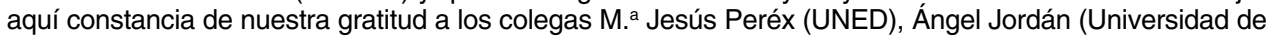
Navarra) y Javier Armendáriz (Gobierno de Navarra) por haber tenido a bien revisar el manuscrito original cuya última versión se ha beneficiado de algunas de sus sabias sugerencias. En cualquier caso, los errores y omisiones que en él pueda percibir el lector son responsabilidad única, exclusiva y última del firmante.

1 PTOL. II, 6, 67.

2 Posiblemente vinculado inicialmente sólo a los valles de los ríos Ega, Arga y Aragón, el territorio de los Vascones experimentó - a costa de sus vecinos- una bien conocida expansión, que ha sido sobradamente tratada por la bibliografía especializada y sobre la que aquí no vamos a abundar. Pueden verse como hitos historiográficos sobre la cuestión: GERMÁN DE PAMPLONA, P.: «LOs límites de la Vasconia hispano-romana y sus variaciones en época imperial", en IV Simposio de Prehistoria Peninsular. Pamplona, 1966, págs. 207-221; FATÁs, G.: «Aproximación al estudio de la expansión vascona en los siglos II y I antes de Cristo", ED, 20, (1972), págs. 383-390; SAYAS, J. J.: «De historiae Vasconiae rebus controversis", en Primer Congreso General de Historia de Navarra, 1. Ponencias. Pamplona, 1987, págs. 89-124, (esp. Págs. 104-109); nuevamente FATÁs, G.: «Notas sobre el territorio vascón en la edad antigua», Veleia, 2-3, (1987), págs. 383-397; BELTRÁN LLORIS, F.: «Hacia un replanteamiento del mapa cultural y étnico del Norte de Aragón", en VILLAR, F., y Fernández Álvarez, M. ${ }^{a}$ P. (eds.): Religión, lengua y cultura prerromana de Hispania. Salamanca, 2001, págs. 61-91 (esp. Págs. 69-72); y —a modo de síntesis crítica- JORDÁN, A.: «La expansión vascónica en época republicana: reflexiones en torno a los límites geográficos de los Vascones», en ANDREU, J. (ed.): Navarra en la Antigüedad: Propuesta de Actualización. Pamplona, 2006, págs. 81-110. Bastará decir, eso sí, que —como apuntamos seguidamente-y comoditatis causa, el marco geográfico de nuestro trabajo va a ser el que se desprende que debía ser solar vascón -lo fuera o no ab origine- cuando escribe Ptolomeo por más complicada que pueda resultar la filiación vascona de algunas de las ciuitates que el geógrafo alejandrino menciona en su célebre listado, asunto que ha preocupado últimamente a la investigación. Al respecto, puede verse SAYAS, J. J.: «Algunas consideraciones en torno a la vascona Alauona», en Homenaje al Profesor Presedo. Sevilla, 1994, págs. 297-304 y «Cuestiones relacionadas con la etnia histórica de los vascones», en Ro-
} 
tivos bien dispares, la información de los autores antiguos que transmiten noticias sobre las ciuitates pertenecientes a la etnia histórica de los Vascones resulta igualmente desigual. Así, cuando Estrabón cita algunas ciuitates vásconas lo hace en el contexto de su descripción geográfica del Norte Peninsular³; las menciones de Tito Livio apenas aportan más información que la del carácter sertoriano o pompeyano de las ciuitates por él referidas ${ }^{4}$; el listado de Plinio el Viejo, por su parte, tiene una naturaleza administrativa que nos ha permitido, eso sí, contar con una imagen bien definida de los estatutos jurídicos de que disfrutaban las referidas comunidades en la época en que deben fecharse las fuentes en que bebe el Naturalista5; los Itinerarios mezclan los conceptos - bien distintos- de mansio y de ciuitas $^{6} ; \mathrm{y}$, por último, Ptolomeo nos obsequia con una controvertida relación de coordenadas de latitud y longitud y unas no menos problemáticas menciones a ciuitates que sólo en él constatamos como vásconas ${ }^{7}$. Por último, estudiar el proceso de monumentalización de un catálogo de ciuitates algunas de cuyas reducciones arqueológicas están aun abiertas y hacerlo en un territorio en el que los yacimientos arqueológicos calificados como urbanos que se han excavado de forma sistemática apenas alcanza la media decena tampoco se antoja tarea fácili. Es por

dríguez Neila, J. F., y Navarro, F. J. (eds.): Los pueblos prerromanos del Norte de Hispania: una transición cultural como debate histórico. Pamplona, 1998, págs. 89-139.

${ }^{3}$ STR. III, 4, 10 que cita Calagurris en el contexto de su descripción del Ebro y, algo más adelante, en relación a la vía que unía Tarraco con Oiasso menciona Pompelo y esa última ciudad cantábrica.

${ }^{4}$ LIV. Per. XCl, donde se menciona el ager Cascantinorum et Graccuritanorum devastado por Sertorio y se alude, en idéntico contexto, a Calagurris Nasica, urbs sociorum, por tanto sertoriana.

${ }_{5}$ PLIN. HN. III, 3, 24, a propósito del territorio del conuentus Caesaraugustanus menciona la comunidad de ciues Romani de los Calagurritani qui Nasici cognominantur, las de Latium uetus de los Cascantenses y Graccuritani; la foederata de los Tarracenses; y las stipendiariae de los Andelonenses, Aracelitani, Carenses, Iluberitani, lacetani, Pompelonenses y Segienses, comunidades todas de las que no reseña su carácter vascón —que el Naturalista sólo deja claro para el caso de Oiasso en $H N$. IV, 20, 110, a la que incluye en el Vasconum saltus - que, sin embargo, puede inferirse del listado ptolemaico arriba referido.

${ }^{6}$ El Itinerario de Antonino cita Cascanto y Calagorra (It. Ant., 392, 2 y 393, 1 respectivamente) en la uia de Caesaraugusta a Verouesca (uia I del Itinerarium: De Italia in Hispanias ad Legionem VII Geminam); Allobone (It. Ant., 444, 1) en la uia que por Turiasso se dirigía a Caesaraugusta (uia XXVIII del Itinerarium: Item a Turassone Caesaraugustam); Graccurris (It. Ant., 450, 5) en la uia que desde Asturica se dirigía a Tarraco (uia XXXII del Itinerarium: Item ab Asturica Terracone); y Aracaeli, Alantone, Pompelone, Turissa, Summo Pyreneo e Imo Pyreneo (It. Ant., 455, 3-8, respectivamente) en la uia que unía Hispania y Aquitania (uia XXXIV del Itinerarium: De Hispania in Aquitania). Por su parte, el Cosmógrafo de Ravena cita Beldalin, Erguti y Beturri (Rav., 312, 1-3 respectivamente) así como Seglam, Terracha, Carta, Pompelone e Iturissa (Rav., 311, 10-14 respectivamente) y Ossaron (Rav., 308, 7 y 318, 2). En el presente trabajo, centrado en los avatares urbanísticos de las ciuitates - y como hemos hecho en otro lugar (ANDREU, J.: "Ciudad y territorio en el solar de los Vascones en época romana», ANDREU, J. (ed.): op. Cit. (n. 2) pág. 213) - sólo abordaremos el estudio de aquellas mansiones que aparecen también referidas como ciuitates sea en Plinio sea en Ptolomeo dejando fuera de nuestro análisis, por tanto, Alantone, Summo e Imo Pyreneo, y Beldalin que, por su exclusiva mención en los documentos viarios no debieron pasar de la condición de mansiones al servicio de la vía. Para ellas, puede verse una síntesis bibliográfica en ANDREu, J.: op. Cit., pág. 214-215, nota 217.

7 PTOL. II, 6, 67, cita como comunidades de los Vascones Iturissa, Pompelón, Biturís, Andelos, Nemanturísta, Curnónion, lácca, Gracchurís, Calagorína, Básconton o Cásconton, Ergauia, Tárraca, Muscaría, Sétia y Alauóna. Para una crítica de cada una de estas menciones puede verse GARCía ALONSO, J. L.: La Península Ibérica en la Geografía de Claudio Ptolomeo. Vitoria, 2003, págs. 387-397.

${ }^{8}$ Las condiciones que fueran descritas en su día para la documentación arqueológica de la parte navarra del solar vascón por GARCíA, M. ${ }^{a}$ L.: «La ocupación del territorio navarro en época romana», 
ello que el presente trabajo está concebido, especialmente, como una puesta al día de los conocimientos de que -a través de las fuentes literarias, arqueológicas y epigráficas- disponemos sobre el hecho urbano en el territorio de la antigua etnia histórica de los Vascones y, fundamentalmente, como un espacio para constatar las reflexiones críticas que el correspondiente material nos suscita. Además, en la bibliografía sobre los Vascones, el asunto de la monumentalización de sus comunidades cívicas -al margen de las utilísimas noticias recogidas por M. ${ }^{a}{ }^{J}$. Peréx ${ }^{9}$ y del clásico trabajo de M. ${ }^{a}$ A. Mezquíriz, referido éste último solamente al espacio actualmente navarro del antiguo solar vascón ${ }^{10}$ - apenas sí ha sido objeto de estudio monográfico por parte de la investigación si se exceptúan un poco conocido

CUAUN, 3, (1995), págs. 231-270 no se han alterado en esencia pese al paso de los años y el supuesto avance de la investigación arqueológica (al respecto véase especialmente PERÉX, M. ${ }^{a} \mathrm{~J}$.: «El poblamiento vascónico en Navarra: visión general y últimas novedades», en ANDREU, J. (ed.): op. Cit. (n. 2), págs. 70-80 y también, con bibliografía, SAYAS, J. J.: «Protohistoria e historia de los vascones. Balance historiográfico (1983-2003)», Vasconia, 34, (2005), págs. 89-116, esp. Pág. 91). A día de hoy sigue vigente el listado de yacimientos urbanos sobre los que hay algo más que noticias de hallazgos en superficie, a saber: Cascantum, Iturissa, Andelo, Pompelo y Cara (GARCíA, M. ${ }^{a}$ L.: op. Cit., págs. 235, 235236, 238-239, y 240-241 respectivamente, con las oportunas referencias bibliográficas, sobre las que volveremos). Si salimos de la Comunidad Foral tampoco mejora -o al menos no lo hace considerablemente- el estado de nuestra documentación pues sólo se han venido desarrollando excavaciones sistemáticas en los solares de Gracchurris (una síntesis de los resultados con toda la bibliografía de las diferentes actuaciones puede verse en HERNÁNDEZ VERA, J. A.: «La fundación de Graccurris», en JIMÉNEZ, J. L., y RiBERA, A. (coords.): Valencia y las primeras ciudades romanas de Hispania. Valencia, 2002, págs. 173-182), Calagurris (a modo de síntesis EsPINOSA, U.: Calagurris lulia. Calahorra, 1984, págs. 111-132), y Oiasso (con toda la bibliografía puede verse Fernández OchoA, C., y Morillo, A.: De Brigantium a Oiasso. Una aproximación al estudio de los enclaves marítimos cantábricos en época romana. Madrid, 1994, págs. 149-188). Para el resto de enclaves, las actuaciones arqueológicas han sido esporádicas cuando no de urgencia (casos, por ejemplo, de lacca - ONA, J. L., PAZ, J., PÉREZ, J. A., y DE SUS, M. ${ }^{a}$ L.: Arqueología urbana en Jaca: el solar de las Escuelas Pías. Jaca, 1987; Juste, M. N., y PALACín, M. V.: «Excavación arqueológicas en el Campaz, Jaca», Bolskan, 4, (1987), págs. 133-146; PAZ, J.: «Solar del antiguo Colegio de los PP. Escolapios (Jaca, Huesca)», Arqueología Aragonesa, 1986-1987. Zaragoza, 1991, págs. 333-335; ONA, J. L., y PALACín, M. V.: «Excavación del solar de C/Correos, esquina C/Ramiro I. Jaca, Huesca», Arqueología Aragonesa, 1986-1987. Zaragoza, 1991, págs. 342-342; y JUSTE, M. N.: «Excavaciones en el solar de la C/7 de Febrero de 1893-esquina con la C/Cambras, de Jaca», Arqueología Aragonesa, 1990. Zaragoza, 1992, págs. 271-274-e igualmente de Segia - LANZAROTE, M. ${ }^{a}$ P.: «Excavaciones arqueológicas en la Plaza de Santa María, Ejea de los Caballeros (Zaragoza)", Suessetania, 13, (1993), págs. 66-67-). El ejemplo de Tarraca —que, con Peréx, M. a J.: Los Vascones, el poblamiento en época romana. Pamplona, 1986, pág. 232, proponemos identificar con el despoblado de Los Bañales de Uncastillo (Zaragoza) - resulta, en este sentido, bien ilustrativo sobre la problemática que acompaña a la documentación arqueológica de las comunidades del antiguo solar vascón: apenas se cuenta con datos de las históricas y pioneras campañas de excavación de GALIAY, J.: Las excavaciones del Plan Nacional de Los Bañales de Sádaba (Zaragoza). Madrid, 1944 y a partir de ellos, los resultados de las campañas desarrolladas en los años setenta y en los ochenta apenas pueden rastrearse -al margen de publicaciones monográficas sobre las obras públicas del yacimiento, que más adelante citaremos (véase notas 135-136 y 160-161) y de una superada pero útil visión de conjunto obra de BELTRÁN LLORIS, F.: «El planteamiento urbano de Los Bañales», en Symposion de Ciudades Augusteas, II. Zaragoza, 1976, págs. 153-164-a través de la práctica - pero divulgativa - síntesis de ZAPATER M. A.: Los restos arqueológicos de Los Bañales, Uncastillo (Zaragoza). Zaragoza, 1995, permaneciendo inéditos gran parte de los materiales en ellas exhumados. Para Navarra, también ha sucedido algo parecido con el yacimiento de Cara, para el que sin embargo, pronto se contará con la actualización documental oportuna gracias a MezQuíRIZ, M. A.: «La antigua ciudad de los Carenses», TAN, 19, (2006), pp. 147-267.

9 Peréx, M. ${ }^{a}$ J.: op. Cit. (n. 8), págs. 75-231.

10 Mezquíriz, M. a A.: "Claves del urbanismo romano en el territorio de Navarra», Complutum, 6, (1996), págs. 441-449. 
trabajo de J. J. Sayas ${ }^{11}$; una visión general —con carácter crítico y de síntesis, por tanto útil- planteada por J. Núñez ${ }^{12}$; y las noticias y bibliografía que sobre las ciudades vásconas del actual territorio aragonés pueden seguirse en un igualmente útil estudio firmado por M. Beltrán Lloris ${ }^{13}$.

1.

Como ya hemos adelantado, ante unas fuentes de naturaleza tan dispar es evidente que nuestro grado de conocimiento de las ciuitates de los Vascones será, igualmente, desigual. Ya hemos apuntado en otro lugar ${ }^{14}$ como en el elenco de las comunidades cívicas que puede suponerse pertenecieron a esta etnia histórica, las que más dificultad presentan para su reducción geográfica son aquellas que tan sólo conocemos en la mención de un solo autor, a saber, lluberi -que sólo es citada por Plinio-, Curnonium, Ergauia, Nemanturista y Muskaria —que tan sólo están presentes en los listados ptolemaicos-.

El asunto de la identificación de las comunidades de los Vascones ha despertado siempre la atención de los estudiosos, siendo objeto de preocupación ya en los pioneros trabajos de $\mathrm{A}$. de Oihénart y de $\mathrm{J}$. de Moret ${ }^{15}$. A partir de ellos, la primera visión pormenorizada del asunto la dio J. Altadill ${ }^{16}$, estudio que condicionó notablemente a la investigación ulterior pues sus conclusiones fueron posteriormente repetidas - muchas veces sin el deseable espíritu crítico-por los citadísimos

11 SAYAS, J. J.: «Transformaciones urbanísticas de las ciudades de los vascones», en SANTOS, J. (ed.): Indígenas y Romanos en el Norte de la Península Ibérica. XI Curso de Verano de la Universidad del País Vasco. San Sebastián, 1993, págs. 227-256.

12 NúÑEZ, J.: «La arquitectura pública de época romana en el País Vasco y sus áreas geográficas limítrofes. Una aproximación crítica», Iberia, 1, (1998), págs. 115-144.

13 Beltrán Lloris, M.: «La ciudad clásica en Aragón», en LACARRA, C. (ed.): Difusión del arte romano en Aragón. Zaragoza, 1996, págs. 37-104.

14 AndReu, J.: op. Cit. (n. 6), pág. 203.

15 OıHÉnART, A. de: Notitia Vtriusque Vasconiae, tum Ibericae, tum Aquitanicae, qua praeter situm regionis et alia digna, Navarrae Regum, Gasconiae Principum, caeterarumque, iniis, insignium vetustae et dignitate familiarum stemmata ex probatis Authoribus et vetustis monumentis exhibentur. París, 1633 [edición del Parlamento Vasco. Vitoria, 1992], págs. 132-138 y MoRET, J. de: Investigaciones históricas de las antigüedades del Reyno de Navarra. Pamplona, 1665 [edición de la Imprenta de Pasqual Ibáñez. Pamplona, 1766], págs. 11-15 y 50-62. Sobre sus contribuciones a la historiografía sobre los Vascones pueden verse RAMíREZ SÁDABA, J. L.: «La historiografía sobre la Navarra Antigua: una visión de conjunto», en ANDREu, J. (ed.): op. Cit. (n. 2), págs. 28-29 —especialmente para José de Moret-y ANDREU, J.: «La imagen de la Navarra Antigua y de los Vascones en la historiografía del Antiguo Régimen, de P. Sandoval (1614) a J. Yanguas y Miranda (1840)», en VI Congreso General de Historia de Navarra: Navarra: Memoria e Imagen. Pamplona, 2006, págs. 23-42.

16 AltADILL, J.: «De re geographica-histórica. Vías y vestigios romanos en Navarra», en Homenaje a D. Carmelo de Echegaray. Pamplona, 1928, págs. 465-556, que planteó las reducciones Cascantum/Cascante (págs. 474-475); Aracilum/Araciel (págs. 476-477); Iturissa/Espinal (págs. 504-506); Ilumberi/Lumbier (pág. 515, nota 1); Bituris/Vidaurreta (pág. 502); Curnonium/Cornaba (pág. 501); Tarraca/Larraga (pág. 469); Muskaria/Tudela (pág. 468) y Ergauia/Milagro (pág. 536) al margen de las que no ofrecían dudas como Pompelo/Pamplona (pág. 501, nota 1); Cara/Santacara (pág. 529); o Andelo/Andión (págs. 534-535). 
trabajos de A. Schülten y P. Bosch-Gimpera ${ }^{17}$ cuyas propuestas de reducción geográfica fueron revisadas en detalle en los ochenta por J. J. Sayas y por M. ${ }^{a}$ J. Peréx ${ }^{18}$ y sobre las que recientemente han vuelto - con conclusiones que ya hemos comentado en otro lugar ${ }^{19}-$ A. M. ${ }^{a}$ Canto $^{20}$ y J. L. Ramírez Sádaba ${ }^{21}$.

En toda esta producción historiográfica sobre el tema - y al margen de las indiscutibles identificaciones Alaun/Alagón22; Andelo/Andión; Calagurris/Calahorra;

17 SCHÜLTEN, A.: «Las referencias sobre los Vascones hasta el año 810 después de J. C.», RIEV, 18, (1927), págs. 225-240 (esp. Págs. 230-233) y Bosch-GIMPERA, P.: «Los celtas y el País Vasco», RIEV, 23, (1932), págs. 457-486 (esp. Pág. 458, nota 1). Ambos apenas discreparon con J. Altadill aunque abordaron reducciones que afectaban a comunidades ajenas al territorio actualmente navarro como Segia/Ejea de los Caballeros (pág. 231 y pág. 458, nota 1, respectivamente), lacca/Jaca (pág. 458, nota 1), Oiasso/Oyarzun (pág. 232) o Gracchurris/Alfaro-Araciel (pág. 458, nota 1).

18 SAYAS, J. J.: «El poblamiento romano en el área de los Vascones», Veleia, 1, (1984), págs. 289-

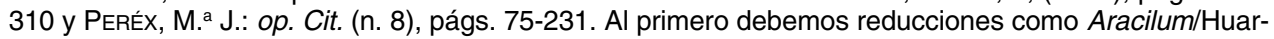
te-Araquil (pág. 301, sobre la que poco después, y solucionando la homonimia Aracilum-bacaudae Aracelitani de HYD., Chron. 128, volvería PERÉx, M. a J.: «En torno a la localización de Aracilus (Navarra)», HAnt., 14, 1990, págs. 135-137) u Oiasso/Irún (especialmente en SAYAS, J. J.: «La civitas de Oiasso y el límite norteño entre vascones y várdulos», Veleia, 8-9, (1991-92), págs. 193-217, esp. Pág. 194); a la segunda las propuestas Tarraca/Los Bañales de Uncastillo (pág. 232, sobre la que luego volvió en «Tarraca, ciudad federada del convento jurídico Caesaraugustano», en De les estructures indigénes a I'organització provincial romana de la Hispania Citerior. Barcelona, 1998, págs. 299-300, esp. pág. 298 y que, en esa misma época, propuso también LABE, L. F.: «Sobre una posible centuriación romana próxima a Los Bañales (Uncastillo)», en XVII Congreso Nacional de Arqueología. Zaragoza, 1985, págs. 831-837, esp. Pág. 833) y la interesante Nemanturista/Sos del Rey Católico (pág. 180, nota 3, siguiendo una reflexión de Tovar, A., y BLÁzQuez, J. M. a: Historia de la Hispania Romana. Madrid, 1975, pág. 353 que la buscaban al Norte de lacca).

${ }_{19}$ AndReu, J.: op. Cit. (n. 6), págs. 179-228.

20 CANTO, A. M. a: «La tierra del toro. Ensayo de identificación de ciudades vasconas», $A E A, 70$, (1997), págs. 31-70 y «Una nueva imagen de Ptolomeo: hipótesis de ubicación de ciudades vasconas», en VILLAR, F., y BELTRÁn LLORIS, F. (eds.): Pueblos, lenguas y escrituras en la Hispania prerromana. Actas del VII Coloquio sobre lenguas y culturas paleohispánicas (Zaragoza, 12 a 15 de Marzo de 1997). Salamanca, 1999, págs. 339-357.

${ }^{21}$ Ramírez SÁdABA, J. L.: «Las ciudades vasconas según las fuentes literarias», en Homenaje a Antonino González Blanco, (en prensa) s. págs., a quien hemos de agradecer que nos haya permitido trabajar con el manuscrito inicialmente presentado al coloquio celebrado en Aramaioa en 2003.

${ }_{22}$ Sigue pendiente la localización del yacimiento arqueológico solar de la antigua Alaun, también conocida ceca prelatina (Beltrán MARTínez, A.: Curso de Numismática. Cartagena, 1950, págs. 325-328). Su reducción a Alagón no ofrece dudas por la homofonía toponímica, por la pervivencia del topónimo en la documentación medieval (RIsco, P. M.: España Sagrada. Tomo XXXII. La Vasconia, tratado preliminar de las Santas Iglesias de Calahorra y de Pamplona, en que se establecen todas las Antigüedades civiles concernientes a la región de los Vascones desde los tiempos primitivos hasta los reyes primeros de Navarra. Madrid, 1878, pág. 93, que recoge la alusión a un Archidiaconus Alauonensis ya citada por ZuRITA, J.: Anales de la Corona de Aragón. Zaragoza, 1610 [edición de Anubar, Valencia, 1967], pág. 182), por la mención a la misma desaprobando la venta a Salduie de unos terrenos para una conducción de aguas incoada por la ciuitas Sosinestana (CIL, I2 $3951 \mathrm{a}=\mathrm{FATÁs}$, G.: Contrebia Belaisca (Botorrita, Zaragoza). II. Tabula Contrebiensis. Zaragoza, 1980) y por la situación de encrucijada — presumiblemente junto a la desembocadura del Jalón y a la orilla derecha del Ebro- que, como ha destacado AsENSIO, J. A.: La ciudad en el mundo prerromano en Aragón. Zaragoza, 1995, pág. 55 caracteriza todavía hoy a la actual localidad zaragozana de Alagón. En este sentido, no ha faltado, incluso, quien la ha buscado en la margen izquierda del Ebro lo que encajaría mejor con la filiación vascona de esta ribera del citado río (al respecto, véase PÉREZ, J. A.: «La evolución de los modelos de ocupación humana del Bajo Jalón a la luz de los vestigios detectados por medio de la prospección arqueológica», en El Jalón, vía de comunicación. Soria, 1990, págs. 73-107 que recoge antiguas noticias de GALIAY, J.: Prehistoria de Aragón. Zaragoza, 1945, pág. 43 sobre el yacimiento de El Castellar, situado frente al municipio zaragozano de Torres de Berrellén). 
Cara/Santacara; Cascantum/Cascante ${ }^{23}$; Gracchurris/Alfaro; lacca/Jaca; Iturissa/Espinal24; Oiasso/Irún; Pompelo/Pamplona; y Segia/Ejea de los Caballeros y de las recientemente cerradas Curnonium/Los Arcos ${ }^{25}$, Ilumberi/Lumbier ${ }^{26}$ y Aracilum/Huarte-Araquil27 - la suerte de algunas de estas propuestas ha resultado desigual. Así, por ejemplo, con noticias bastante difusas sobre hallazgos romanos se ha venido manteniendo sin crítica la reducción Muskaria/Tudela mientras apenas ha prosperado la - a nuestro juicio sobradamente documentada - de Tarraca/Los Bañales de Uncastillo ${ }^{28}$. Al tiempo, se ha desoído la información de la historiografía tradicional - que siempre aporta datos útiles al respecto- sobre dos de las reducciones más complicadas del catálogo: Nemanturista y Ergauia. Queremos, pues, detenernos aquí en algunas novedades respecto de algunas de estas ciui-

${ }^{23}$ Aunque sugerente como hipótesis de trabajo, la reciente idea de BIENES, J. J.: «Desde la Prehistoria hasta el siglo IX», en El patrimonio histórico y medioambiental de Tudela: una perspectiva interdisciplinar. Tudela, 2001, págs. 12-21, esp. Pág. 15 que —amparándose en la ausencia de niveles arqueológicos prerromanos en Cascante- plantea un traslado de la Kaiskata celtibérica desde el cerro de Santa Bárbara (Tudela) al solar de la actual Cascante en época romana encuentra hoy día obstáculos notables no sólo en la evidente relación de homofonía Kaiskata=Cascante sino también en la presencia de destacados poblados de la Edad del Hierro en el entorno de la localidad de la Ribera, documentados por ARMENDÁRIZ, J.: El proceso de formación de las comunidades urbanas en la Navarra Sedimentaria durante el Primer Milenio antes de Jesucristo, (Tesis Doctoral, inédita), UNED, 2003, págs, 469 y 622 a quien agradecemos habernos permitido acceder a su utilísimo trabajo. Desarrollando dichos argumentos puede verse: SAYAS, J. J.: «La comarca de Tudela, esquema de comprensión de un desarrollo regional en la época Prerromana y Romana», ETF (II), 15, (2004), págs. 139-166, esp. Págs. 150-152. Nosotros hemos trazado una panorámica de la cuestión en ANDREU, J.: «Aspectos del poblamiento en la Comarca de Tudela de Navarra en época romana», Cuadernos, 4, (en prensa), s. págs.

${ }^{24}$ Con bases arqueológicas desde PERÉx, M. ${ }^{a}$ J., y UNZU, M.: «Resumen de las campañas de 19861987: emplazamiento de Iturissa, mansio en la vía de Astorga a Burdeos», TAN, 7, (1988), págs. 335339 , sobre las que luego volveremos.

${ }_{25}$ Recientemente, ARMENDÁRIZ, J.: «Bases arqueológicas para la localización de la ciudad vascona de Curnonium en Los Arcos (Navarra)», TAN, 19, (2006), págs. 85-108, ha realizado diversas intervenciones arqueológicas en el castillo de la localidad navarra de Los Arcos suficientemente probatorias de la identificación propuesta.

${ }_{26}$ Aunque ya existían noticias de antigüedades romanas en Lumbier en ALTADILL, J.: op. Cit. (n. 16), pág. 462, ha sido Castiella, A.: Por los caminos romanos de Navarra. Pamplona, 2003, pág. 99 quien ha vuelto sobre ellas a partir de los datos de las excavaciones de RAMOS, M.: «Excavaciones en la ciudad romana de Ilumberis (Lumbier, Navarra)», en XVI Congreso Nacional de Arqueología (Zaragoza, 2001), (en prensa), s. págs.

27 Al margen de las intuiciones de los historiadores - que veían con buenos ojos la proximidad Aracilum-río Araquil-valle del Araquil (véase, en este mismo trabajo, nota 18) — un erudito local, CASATORRE, R.: Barracanca-Burunda. Pamplona, 1993, págs. 12-14 ha dado noticia de materiales arqueológicos recogidos en el entorno de la localidad navarra de Huarte-Araquil. Hace no mucho -y con resultados que permanecen aun inéditos - la empresa de Arqueología Olkairun ha realizado diversos sondeos arqueológicos que le han permitido contactar con importantes estructuras muebles de época imperial romana en el entorno del Monasterio de Santa María de Zamarce, junto al río Araquil y que debían incluir un establecimiento termal (Diario de Navarra, 25-8-2005), restos que, sin duda, vienen a sancionar la identificación mantenida hasta entonces sólo por la fundada homofonía. Agradezco la noticia al arqueólogo Javier Armendáriz, experto conocedor del día a día de la investigación arqueológica en la actual Comunidad Foral.

${ }^{28}$ Contra dicha reducción, sin argumentos de peso, puede verse MAgALLón, M. ${ }^{\text {a }}$ A.: «Vías de comunicación y poblamiento romano en la Comarca de las Cinco Villas», en Los Caminos en la Historia de las Cinco Villas (Ejea, 1990). Zaragoza, 1995, págs. 21-42, esp. Págs. 40-41 y Beltrán Lloris, M.: op. Cit. (n. 13), pág. 76, n. 192. Nosotros hemos vuelto recientemente sobre ella en ANDREU, J.: «Un dispensator publicus en territorio vascón: a propósito de AE, 1971, 199», en EICHMANN, A. (ed.): Classica Boliuiana, (en prensa), s. págs. 
tates de los Vascones aventurándonos, en algunos casos, a trazar hipótesis asentadas - a nuestro juicio- sobre bases cuando menos probables y, que lógicamente, sólo podrán ser refrendadas cuando sea mayor la documentación con que en la actualidad podemos contar al respecto de las mismas.

\section{1.}

Efectivamente, toda la historiografía ha venido manteniendo, la reducción de Muskaria al despoblado de Mosquera, entre Tudela y Fontellas ${ }^{29}$ para la que -al margen de las sucintas noticias de hallazgos arqueológicos dadas por J. Altadill ${ }^{30}$, en las que abundaron B. Taracena y L. Vázquez de Parga, que documentaron restos arqueológicos cerámicos, numismáticos y constructivos ${ }^{31}$ — sin embargo, las recientes remociones de tierra llevadas a cabo en el entorno de la denominada Mejana de Mosquera fruto de las obras de construcción de la variante Este de Tudela apenas han aportado elementos arqueológicos romanos y sólo material islámico ${ }^{32}$. A nuestro juicio - y aunque nos hemos pronunciado de forma contraria en otro lugar $^{33}$ - de no ser que Ptolomeo esté confundiendo pólis con uicus/pagus - como, por otra parte, sucede con su alusión ${ }^{34}$ a la vecina Belsinon (Mallén) - y dejando un margen de posibilidad a una eventual destrucción de los niveles arqueológicos fruto de las labores de la concentración parcelaria acometidas en los años cincuenta en la zona por el Ministerio de Agricultura o bien al hecho de que las alteraciones fluviales del río Ebro hayan podido arrasar — con sus meandros- el so-

${ }_{29}$ Altadill, J.: op. Cit. (n. 16), pág. 500; reducción seguida después por Schülten, A.: op. Cit. (n. 17), pág. 231, Bosch-Gimpera, P.: op. Cit. (n. 17), pág. 458, n. 1, y, desde ellos, mantenida sin grandes revi-

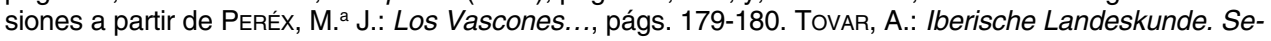
gunda Parte. Las tribus y las ciudades de la antigua Hispania. Tomo 3. Tarraconensis. Baden-Baden, 1989, pág. 405, sin embargo, mantuvo Muskaria entre las ciuitates de ubicación desconocida y la Tabula Imperii Romani. Hoja K-30. Madrid. Madrid, 1993, deja aun como dudosa esta propuesta. Hasta la fecha, tan sólo Germán de Pamplona, P.: op. Cit. (n. 2), pág. 209 -que la localizó más al Oeste de Gracchuris en una complicada interpretación de las coordenadas ptolemaicas-y ALBERTOS, M. ${ }^{a}$ L.: "La antroponimia en las inscripciones hispano-romanas del País Vasco», ED, 20, (1972), págs. $352-353$ esp. Pág. 353 - que propuso la actual localidad zaragozana de Sádaba, donde encaja mejor Tarraca dada su situación entre Segia y Cara a juzgar por los datos de Rav., 311, 10-12- han presentado propuestas discordantes. Recientemente, Rubén, J.: Diccionario toponímico y etnográfico de Hispania Antigua. Madrid, 2004, pág. 366 ha resumido el debate inclinándose por el espacio entre Tudela y Fontellas al que nos venimos refiriendo.

30 Altadill, J.: op. Cit. (n. 16), págs. 529-530.

31 TARAcenA, B., y VÁzquez de PARGA, L.: «V. La Romanización», Excavaciones en Navarra 1 (19421946). Pamplona, 1946, págs. 95-149, pág. 438. Más adelante también en TARACENA, B., y VÁZQUEZ DE PARGA, L.: «Excavaciones en Navarra. VI. La 'villa` romana del Ramalete (término de Tudela)», PV, 34, (1949), pág. 8, n. 11 y pág. 11, noticias de las que se ha hecho eco la investigación posterior, al margen de los más concretos datos aportados por AmARÉ, M. ${ }^{a}$ T.: «Lucernas romanas de Navarra», TAN, 5, (1986), págs. 175-193, pág. 176, citando a BIENES, J. J.: Carta arqueológica del término municipal de Tudela, (inédito), s. págs. y que los autores vincularon a una uilla rústica romana.

32 Agradezco nuevamente el dato al arqueólogo Javier Armendáriz, del Gobierno de Navarra, que acudió al lugar en el invierno de 2005 con motivo del avance de las referidas obras.

33 Andreu, J.: op. Cit. (n. 6), págs. 207-208.

34 PTOL. II, 6, 57, entre las poléis de los Celtiberoi. 
lar de los mismos, lo cierto es que el carácter difuso de las noticias arqueológicas con que contamos para el despoblado tudelano de Mosquera cuando no su inexistencia o su escasa entidad nos lleva a reconocer como solvente y probable la reciente propuesta de A. Jordán ${ }^{35}$, que ha documentado un microtopónimo Muskarria en las cercanías de Vidaurre, en el valle de Guesalaz y que ha buscado en dicha zona la Muskaria ptolemaica. No sólo la documentación arqueológica —con un par de interesantes yacimientos romanos ${ }^{36}$ - y fundamentalmente epigráfica ${ }^{37}$ del entorno del Embalse de Alloz es más acorde con la presencia de una ciuitas ${ }^{38}$ en esta zona sino que, además, no faltan en el área algunos topónimos como Muez o, especialmente, Muzqui, que -al margen del microtopónimo antes citado-bien podrían estar documentando la pervivencia toponímica de la Muskaria de Ptolomeo. En cualquier caso - como sucederá con las identificaciones que proponemos a continuación - la sugerente hipótesis de A. Jordán —que aquí mantenemos- deberá ser refrendada con el avance de la investigación arqueológica que, sin duda, deberá complementar la información dada por los dos topónimos manejados: Mosquera de Tudela y Muskarria de Vidaurre.

\section{2.}

Tan difícil como la reducción de Muskaria resulta la de la pólis ptolemaica de Ergauia. Si el topónimo de aquélla podía explicarse por el latín o por el vasco, ésta última deja pocas posibilidades abiertas más allá de su filiación indoeuropea (no en vano su paralelo más conocido es la Ercauica celtibérica cuyo populus aparece citado por Plinio entre los del conuentus Caesaraugustanus ${ }^{39}$ ) cuestión ésta que - como veremos en seguida - no resulta baladi ${ }^{40}$. Ya J. J. Sayas planteó buscarla en el curso del río Ega ${ }^{41}$, hidrónimo con el que el topónimo que nos ocupa parece guardar relación, planteamiento sobre el que ha vuelto J. L. Ramírez Sádaba $^{42}$. Sin embargo, y aunque J. de Moret aportó abundante documentación acerca de la reducción Ergauia/Milagro ${ }^{43}$, localidad navarra del curso de dicho río, esta propuesta parece no resistir demasiado bien la proximidad de otras importantes

35 Jordán, A.: op. Cit. (n. 2), pág. 95, n. 45.

${ }^{36}$ Se trata de los yacimientos de Iruñuela y de Rezumendía, estudiados por ARMENDÁRIZ, J.: El proceso de formación..., págs. 319-321 respectivamente, este último con notable potencial arqueológico romano.

${ }^{37}$ En este sentido, nótese en el Mapa «Epigrafía Latina en el territorio de los Vascones: Geografía de los Hallazgos y Conjuntos Epigráficos» la densidad de hallazgos epigráficos que ofrecen los pueblos del referido valle: Arguiñáriz, Guezalaz, Lerate, Muez, Muzqui, y Zábal.

38 ANDREU, J., y JORDÁN, A.: «Apuntes para un debate en torno a la localización de la Muskaria de los Vascones», Salduie, 6, (2006), (en prensa), s. págs.

39 PLIN. HN. III, 3, 24.

40 Sobre la cuestión véase: García Alonso, J. L.: op. Cit. (n. 7), pág. 394.

41 SAYAS, J. J.: El poblamiento romano..., pág. 302.

42 Ramírez Sádaba, J. L.: op. Cit. (n. 21), s. pág.

43 Moret, J. de: op. Cit. (n. 15), págs. 48-49, que alude a la mención Erga en distintos documentos medievales relativos a la localidad navarra de Milagro. 
ciuitates como Gracchurris - especialmente-, Andelo o Curnonium lo que nos lleva a plantear buscarla mejor en el alto curso del río Ega, quizás en torno a Gastiáin o a Zúñiga donde no falta documentación epigráfica con onomástica netamente indoeuropea ${ }^{44}$ y sobre cuyo valle -el valle de Lana, drenado por el referido curso fluvial- la historiografía tradicional ha aplicado el sugerente título de «despoblado ${ }^{45}$ », categoría que - como es sabido- suele coincidir con noticias de antiguo poblamiento y que en el caso del ámbito que nos ocupa estaría probada para los casos del de Araciel en Corell $a^{46}$ o del de Andión en Mendigorría. En cualquier caso, sólo una intensiva prospección del bellísimo paraje que se abre al pie de la Sierra de Lóquiz permitirá arrojar más luz al respecto de esta cuestión que aquí no hemos querido sino apuntar a espera, una vez más, de que futuras investigaciones puedan confirmar o rechazar la hipótesis de trabajo que aquí planteamos.

\section{3 .}

Analizando el Mapa que acompaña nuestro estudio llama la atención la notabilísima concentración de documentos epigráficos constatada en el extremo oriental de la Navarra Media, en concreto en un área comprendida en torno a las actuales localidades navarras de Lerga, Aibar, Eslava, Gallipienzo e incluso Sangüesa y en torno, también, al cerro de Santacrís, a medio camino entre Eslava y Gallipienzo. Como ha apuntado recientemente J. Velaza es bastante probable que esta zona depare agradables sorpresas a la investigación epigráfica ${ }^{47} y$, lógicamente, también a la arqueológica. Ya en otro trabajo hemos planteado que en dicha área bien pudiera buscarse alguna de las ciuitates vásconas todavía ignotas apuntando la posibilidad de que la Nemanturista de Ptolomeo tuviese su solar en el referido cerro de Santacrís sobre el que precisamente y por encargo del Servicio de Patrimonio Histórico del Gobierno de Navarra la empresa de arqueología Olkairun está elaborando actualmente un Plan Director orientado a calibrar el indiscutible potencial arqueológico del enclave ${ }^{48}$. Efectivamente, la documentación arqueológica recuperada en el mismo - sobre la que luego volveremos pero que incluye notables materiales constructivos romanos al margen de las bien conocidas

44 Ver Mapa: «Epigrafía Latina en el territorio de los Vascones: Geografía de los Hallazgos y Conjuntos Epigráficos». Sobre la relación onomástica indoeuropea-río Ega, véase RAmíREZ SÁDABA, J. L.: op. Cit. (n. 21), (en prensa), s. págs.

${ }^{45}$ A. A. V. V.: Diccionario Geográfico-Histórico de la Real Academia de la Historia. Sección I. Comprende el Reyno de Navarra, Señorío de Vizcaya, y provincias de Álava y Guipúzcoa. Madrid, 1802 [edición de la Fundación para el Estudio del Derecho Histórico y Autonómico de Vasconia, San Sebastián, 2005], pág. 173, noticia sobre la que luego volvería IDOATE, F.: «Poblados y despoblados o desolados en Navarra (en 1534 y 1800)», PV, 108-109, (1967), págs. 309-330, esp. Págs. 322-326.

46 LacARra, J. M.a: Documentos para el estudio de la Reconquista y repoblación del valle del Ebro. Zaragoza, 1982, págs. 170-176, seguramente identificables con una uilla del ager Vasconum.

47 VelazA, J.: «Crónica de Epigrafía Antigua de Navarra (II)», en AnDREU, J. (ed.): op. Cit. (n. 2), pág. 61.

${ }_{48}$ Agradezco la noticia a la gentileza de M. ${ }^{a}$ Rosa Mateo, de la citada empresa de Arqueología. 
necrópolis de incineración ${ }^{49}$ — sanciona lo que puede desprenderse de la naturaleza de su documentación epigráfica que incluye referencias a liberti, cognomina griegos e incluso una mención a un dispensator publicus municipal ${ }^{50}$ : la existencia de una ciuitas en este enclave, por otro lado ubicado al pie de un ramal de la vía ${ }^{51}$. Como ya apuntara en su día J. L. Ramírez Sádaba ${ }^{52}$, si se tiene en cuenta -con las debidas reservas - el modo como Ptolomeo sitúa la pólis vascona de $\mathrm{Ne}$ manturista - en el mismo paralelo que Andelo pero en latitud opuesta- y ello se pone en relación con la riqueza arqueológica y epigráfica del enclave creemos que la propuesta Nemanturista/Santacrís está asentada sobre bases, cuando menos, verosímiles ${ }^{53}$, bases a las que habría que añadir que el probado carácter vascónico del topónimo Nemanturista - o al menos de su segundo elemento, que en territorio vascón estaría también atestiguado en la ciuitas de Iturissa y que no es descartable relacionar con el vasco -itza ${ }^{54}$ - encaja muy bien en una de las áreas de

49 Para la necrópolis de mausoleos, puede verse una síntesis en ARMEndÁRIZ, R.; MATEO, M. ${ }^{\text {a }}$ R., y SÁEZ DE AlbÉNIZ, M. a P.: «Santa Criz, una necrópolis romana de incineración en Eslava (Navarra)», Isturitz, 9, (1997), págs. 823-841. En el transcurso de los sondeos arqueológicos llevados a cabo en el cerro de Santacrís se han documentado no sólo lienzos de muralla (ARMENDÁRIZ, R.; MATEO, M. ${ }^{a}$ R., y SÁEZ DE AlBÉNIZ, M. a P.: «Primera campaña de excavación en el yacimiento de Santa Criz (Eslava-Navarra)», TAN, 12, (1995-96), págs. 322-326) sino también abundantes materiales constructivos romanos, especialmente sillares -entre los que no faltan los moldurados-, fragmentos escultóricos y capiteles (ARmendáriz, R., Mateo, M. ${ }^{a}$ R., SÁez de Albéniz, M. ${ }^{a}$ P.: Santa Criz, una necrópolis..., pág. 840).

${ }^{50}$ Sobre la epigrafía del entorno de Santacrís y su relación con el hábito epigráfico urbano puede verse ANDREU, J.: op. Cit. (n. 6), pág. 212, nota 191. La pieza del dispensator (AE, 1971, 199) la hemos revisado en ANDREU, J.: «Un dispensator publicus en territorio vascón: a propósito de AE, 1971, 199», en Eıchmann, A. (ed.): Classica Boliuiana, (en prensa), s. págs.

${ }^{51}$ Sobre dicho ramal viario, véase AGUAROD, C., y LostAL, J.: «La vía romana de las Cinco Villas», Caesaraugusta, 55-56, (1982), págs. 167-218. y ARMENDÁRIZ, J., y VELAZA, J.: «El miliario de Garínoain (Navarra), cruce de caminos en la vía entre Cara (Santacara) y Pompelo (Pamplona)», TAN, 19, (2007), (en prensa, s, págs.) Ya MALUQueR, J.: «Las actividades arqueológicas en Navarra», Caesaraugusta, 17-20, (1961-1962), págs. 179-186, pág. 186 situaba Santacrís «entre las ciudades que, como Andelo y Cara constituían una serie de municipios romanizados de la Navarra Media», carácter urbano que recientemente ha remarcado Castiella, A.: op. Cit. (n. 26), pág. 101.

52 Ramírez Sádaba, J. L.: op. Cit. (n. 21), s. pág.

${ }^{53}$ Como se ha dicho (véase nota 18) fue BLÁzQUEZ, J. M.: Estructura económica y social de Hispania durante la anarquía militar y el Bajo Imperio. Madrid, 1964, pág. 169 y más tarde TovAR, A., y BLÁZQUEZ, J. M.: op. Cit. (n. 18), pág. 353 quienes buscaron Nemanturista al Norte de lacca (en esa área, en torno a Siresa la había localizado MüLLER, K.: «Rapports sur les manuscrits de la Géographie de Ptolemée», Archives des missions scientifiques et littéraries, 2, 4, (1867), págs. 279-420, esp. Pág. 398 y por su parte, Madoz, P.: Diccionario Geográfico-Estadístico-Histórico de España y sus posesiones de ultramar. Zaragoza. Madrid, 1845-1850 [edición del Gobierno de Aragón, Zaragoza, 1985], pág. 186 había planteado buscarla en la aldea zaragozana de Sofuentes, noticia de la que, sin citar su procedencia, parece hacerse eco BALIL, A.: «La defensa de Hispania en el Bajo Imperio», Zephyrus, 11, (1960), págs. 179-197, esp. Pág. 188). Peréx, M. ${ }^{a}$ J.: op. Cit. (n. 8), pág. 180, nota 3 planteó la posibilidad de que, dado el error que el geógrafo alejandrino arrastra en la orientación de los Pirineos, quizás sería mejor buscar dicha ciuitas al Este de lacca y por tanto, planteaba ella, en el área de Sos del Rey Católico. Como ha apuntado Ramírez SÁdABA, J. L.: op. Cit. (n. 21), s. pág., la presencia de la ciudad de los Iluberitani en dicho entorno (área de Lumbier) hace plausible desplazar más hacia el Oeste esta propuesta de reducción y, dada la notable documentación arqueológica y epigráfica a que se ha hecho referencia, buscar $\mathrm{Ne}$ manturista en el área de Eslava. En cualquier caso, su localización sigue dándose como indeterminada (García Alonso, J. A.: op. Cit. (n. 7), pág. 389) y nuestra propuesta deberá esperar al avance de la documentación arqueológica y, especialmente, epigráfica.

${ }^{54}$ García Alonso, J. L.: op. Cit. (n. 7), pág. 389, siguiendo a Tovar, A.: op. Cit. (n. 28), pág. 409. 
indiscutible dominio lingüístico vascónico en época antigua como ha documentado J. Velaza ${ }^{55}$.

2.

Cicerón, en el De Officiis ${ }^{56}$ calibraba el poder de integración y de cohesión que la propia estructura material y urbana de la ciudad — concretada en sus obras públicas: forum, porticus, uiae...-generaban en la población del entorno, a su juicio asimilable al modo como actuaban en las distintas gentes y nationes instituciones como las leges, los iura, los iudicia, los suffragia o la propio consuetudo local. Por su parte, equiparando en el concepto de ciudad su dimensión institucional y su realidad material uno de los trabajos clásicos sobre la dimensión arqueológica de la ciudad antigua, el de M. Attilio Levi ${ }^{57}$, resumía en tres elementos básicos los indicadores de la existencia de una ciudad romana, a saber: una fisonomía típica de la urbanística romana, sino campamental sí, cuando menos, ortogonal; una elite que vive en la ciudad, gestiona sus instituciones y exhibe su riqueza en ella o en el entorno; y, por último, una contrastada actividad económica, industrial, comercial y política que convierte a la comunidad en un indiscutible centro de poder.

Partiendo de esos tres parámetros - que, en cierto modo, harán de eje de nuestro análisis de las comunidades de los Vascones - es evidente que para cada uno de ellos la naturaleza de las fuentes de estudio que nos pueden arrojar luz sobre ellos resulta diferente. La documentación arqueológica nos permite contar con datos sobre la fisonomía urbana de la ciuitas y sobre su dedicación económica o comercial mientras que la documentación epigráfica y la estatuaria nos remiten al comportamiento de las elites locales, a las pautas en que se concretó su deseo de autorepresentación y al modo como llevaron a cabo la gestión política de los centros en que vivían.

Antes de abordar la cuestión central del presente trabajo parece aconsejable dedicar siquiera unas líneas a calibrar el estado actual de nuestra documentación respecto de estas tres áreas que - a nuestro juicio- definen muy bien la esencia de la vida ciudadana.

2.1.

Pese a los problemas derivados del propio ritmo de la investigación arqueológica y a los que ya se hizo referencia con anterioridad ${ }^{58}$, el repertorio de datos

${ }^{55}$ VeLAZA, J.: «Epigrafía y dominios lingüísticos en territorio de los vascones», en BELTRÁN LLORIS, F. (ed.): Roma y el nacimiento de la cultura epigráfica en Occidente. Zaragoza, 1995, págs. 209-218, esp. Págs. 213-214.

56 ClC., Off. I, 53.

57 Attilio LeVI, M.: La città antica. Morfología e biografía della aggregazione urbana nell' Antichità. Roma, 1989, págs. 405, 417 y 420.

58 Véase nota 8. 
arqueológicos con que contamos para el estudio de los procesos de monumentalización de las ciudades de los Vascones ofrece un catálogo de datos ciertamente desigual pero en cualquier caso útil como punto de partida y que hemos resumido en la Tabla I que acompaña este trabajo.

Fruto de su análisis - que detallaremos con pormenor en el tercer apartado del presente trabajo y de modo general en el cuarto- y como ya apuntara M. ${ }^{a}$ L. García ${ }^{59}$ puede dibujarse una sintética imagen de la ciudad entre los Vascones, imagen que corrobora - como ha apuntado recientemente J. J. Sayas ${ }^{60}$ - que la propia panorámica urbana y -en definitiva - el proceso de urbanización del antiguo solar vascón es uno de los más evidentes resultados del poder integrador desempeñado por la ciuitas, poder integrador que el solar que nos ocupa debió empezar a experimentar con la fundación de Gracchurris en el 179 a. C., obra de Ti. Sempronio Graco y cuyo proceso histórico detallaremos más adelante a partir del estudio de la documentación arqueológica.

La imagen a que nos venimos refiriendo descansa sobre una serie de rasgos globales que - por otra parte- no difiere mucho de la que manifiesta la realidad urbana en otros puntos del Ebro Medio ${ }^{61}$, a saber: (1) la habitual continuidad del hábitat preexistente de la II Edad del Hierro; (2) la ausencia de niveles violentos de destrucción en la transición a la época romana; (3) la rápida convivencia de elementos culturales romanos e indígenas en época Republicana; (4) el igualmente acelerado proceso de urbanización, concretado en traslados in planum de población, ampliación territorial de los asentamientos y configuración de planes urbanísticos ortogonales adaptados, en ocasiones, a las dificultades y peculiaridades del terreno; (5) la aparente continuidad — bajo las formas administrativas romanas y bajo una especialización funcional de los asentamientos también típicamente romana ${ }^{62}$ - de la jerarquía urbana de los poblados prerromanos Vascones; (6) la oportuna dotación a las ciudades - al menos así puede inferirse de los casos en que la documentación arqueológica ha sido más generosa- de todos y cada uno de los servicios típicos de la infraestructura urbana romana; (7) el apogeo arquitectónico y florecimiento urbanístico registrado a comienzos del siglo II d. C., que

59 GARCíA, M. ${ }^{\text {a }}$ L.: «El poblamiento en época romana en Navarra: sistemas de distribución y modelos de asentamientos», Isturitz, 8, (1997), págs. 75-110.

60 SAYAS, J. J.: “El municipio de Vasconia en el mundo antiguo», en IV Symposium: el municipio foral y actual en los territorios de Vasconia, (en prensa), s. págs., que hemos podido consultar gracias a la amabilidad de nuestro colega.

61 Martín Bueno, M.: «La ciudad hispanorromana en el valle del Ebro», en La ciudad hispanorromana. Barcelona, 1993, págs. 108-127, esp. Págs. 110-112.

62 Al respecto de esa jerarquía, nos parece válido el modelo propuesto por GIL, E.: «El poblamiento en el territorio alavés en época romana», Isturitz, 8, (1997), págs. 23-52, esp. Págs. $29-37$ que, con el hecho urbano como centro, ha catalogado los asentamientos romanos en cuatro clases, a saber: clase 1 («ciudades»), clase 2 («mansiones»), clase 3 («núcleos intermedios sin oferta de servicios») y clase 4 («entidades agrícolas menores»). Creemos que dicho modelo resume a la perfección la tipología del poblamiento romano. En nuestro trabajo - aunque los asentamientos de las clases 2-4 arrojen también información sobre el desarrollo de la vida urbana- nos centraremos especialmente en lo que él denomina establecimientos de clase 1. 
también afectó a la proliferación de yacimientos rurales para la explotación económica del territorio por parte de la elite; (8) la relación ciuitas-territorium concretada a partir de formas particulares de explotación económica (9); el retraimiento de la urbanística - $\mathrm{O}$, al menos, el inicio de su transformación- a partir de los Antoninos; y (10) — hasta donde alcanza nuestra documentación - la considerable reducción del poblamiento —o su definitiva alteración - a partir de finales del siglo III d. C.

Así, por ejemplificar algunos de estos puntos en las ciuitates arqueológicamente mejor conocidas del ámbito vascón consta la segura continuidad del poblamiento -con los oportunos procesos de sinecismo o de agrupación poblacional que recientemente ha estudiado J. Armendáriz ${ }^{63}$ - en los casos de Pompelo, Calagurris, Cara, Gracchurris o Andelo64, hay razones fundadas para presuponer lo mismo para Tarraca aunque las noticias sobre el poblamiento prerromano de esta última resulten ciertamente confusas ${ }^{65}$, y en dicha forma parece deben interpretarse los más antiguos niveles de habitación de la somera estratigrafía estudiada para lacca ${ }^{6}$.

63 ARmendÁRIZ, J.: El proceso de formación... págs. 623 (para el caso de Cascantum) o págs. 624625 (para el de Curnonium) y, para el caso de Pompelo, ARMENDÁRIZ, J.: «Propuesta de identificación del campamento de invierno de Pompeyo en territorio vascón», TAN, 18, (2005), págs. 41-64, esp. Pág. 53.

64 Para el caso de Pompelo puede verse ArmendÁRIz, J.: op. Cit. (n. 63), pág. 53 (con mapa de ubicación de los asentamientos prerromanos); para el de Calagurris —en torno de la cuál también debió operarse un sinecismo desde los vecinos poblados de Los Arbolazos, Campobajo, El Valladar, o La Torrecilla- CAstiella, A.: La Edad del Hierro en Navarra y Rioja. Pamplona, 1977, págs. 152-154; el caso de Cara, apuntado por CASTIELLA, A.: op. Cit., pág. 122, fue tratado de forma monográfica por MEZQuíRIZ, M. ${ }^{a}$ A.: «Cerámica prerromana hallada en las excavaciones de Santacara (Navarra)», en XIV Congreso Nacional de Arqueología. Zaragoza, 1977, págs. 599-610, esp. Págs. 599 y 604, que también se ocupó del de Andelo en «Andelos: secuencia estratigráfica y evolución cronológica», PV, Anejo 7, (1987), págs. 517-530, esp. Pág. 518, y sobre el que ha vuelto recientemente ARMENDÁRIZ, J.: El proceso de formación..., págs. 258-259. Para el caso de Gracchurris - mencionada como llurcis en LIV., Per. XLI-, véase la síntesis de Hernández Vera, J. A.: op. Cit. (n. 8), págs. 175-179.

65 Más oscuro que los casos de las ciuitates anteriormente referidas resulta, efectivamente, el caso de Tarraca. Las noticias sobre éste — si se acepta su identificación con Los Bañales de Uncastillo (Zaragoza) - se reducen a hallazgos de cerámica celtibérica en El Pueyo documentados por GALIAY, J.: La dominación romana en Aragón. Zaragoza, 1949, págs. 22-29, que, sin embargo, no fueron constatados más tarde por BELTRÁN LLORIS, F.: «Sobre las últimas excavaciones en El Pueyo de Los Bañales (Uncastillo, Zaragoza)», en XIV Congreso Nacional de Arqueología (Vitoria, 1975). Zaragoza, 1976, págs. 1055-1060, esp. 1059 y a una bolsada de cerámica prerromana a mano y a torno recuperada en los trabajos de desescombro de las termas, en la zona baja de la Val de Bañales y que su editora (AGUAROD, M. ${ }^{a}$ C.: «Avande al estudio de la cerámica de Los Bañales», en XIV Congreso Nacional de Arqueología. Zaragoza, 1977, págs. 987-994, esp. Pág. 987) interpretó como prueba de una ocupación prerromana del asentamiento. A nuestro juicio, además de que está sobradamente documentado el poblamiento desde la Edad del Bronce a lo largo de todo el valle del Riguel (área de Busal, al Oeste de Layana, en el centro de la Val de Bañales: CASAdo, M. ${ }^{a}$ P., y Burillo, F.: «Nuevos hallazgos de la Edad del Bronce en las Cinco Villas (Zaragoza)», en XIV Congreso Nacional de Arqueología. Zaragoza, 1977, págs. 297-300) no se olvide que si se acepta la reducción de este yacimiento con la Tarraca cuyo populus es mencionado por Plinio como el único foederatus del conuentus Caesaraugustanus parece lógico buscar en la época de los inicios de la conquista la razón de dicho foedus lo que, lógicamente, exige un poblamiento para dicho momento. Sobre este tema, veáse, en este mismo trabajo nota 186.

66 Ona, J. L., Paz, J., Pérez, J. A., y De Sus, M. ${ }^{a}$ L.: op. Cit. (n. 8), pág. 11, con niveles del siglo II a. C. con cerámicas de técnica ibérica a torno y PAZ, J.: op. Cit. (n. 8), pág. 334, con fragmentos de muralla y puerta de acceso. 
Por su parte, de la temprana convivencia de elementos de tradición indígena con otros netamente romanos en época Republicana nos encontraríamos no sólo con pruebas arqueológicas - como el ya célebre mosaico en opus signinum hallado en Andelo y que exhibe una inscripción paleohispánica ${ }^{67}$ y otros de idéntica factura hallados en la Plaza de San José de Pamplona o en las faldas de la colina de Nuestra Señora del Romero en Cascante ${ }^{68}$ — sino, a juicio de J. Velaza, también con evidencias lingüísticas dada la convivencia de diversos dominios lingüísticos atestiguada para esta época en el antiguo solar vascón ${ }^{69}$. De igual modo deben interpretarse los estratos arqueológicos que - para los yacimientos de Pompelo/Plaza de San José ${ }^{70}$, Gracchurris ${ }^{71}$, Cara ${ }^{72}$, Tarraca/ ¿El Pueyo ${ }^{73}$ o lacca/Escuelas Pías $^{74}$ - nos ponen en contacto con la convivencia de formas cerámicas romano-itálicas de fecha temprana como la Campaniense $A$ y $B$ y cerámicas indígenas, aspecto éste que podría ser puesto en relación con la presencia de tropas acantonadas durante el proceso de conquista en los distintos campamentos militares cuya localización en territorio vascón ha sido propuesta por la investigación ${ }^{75}$.

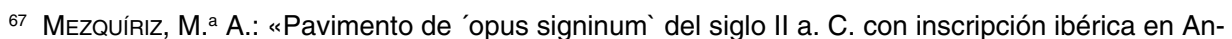
delos», TAN, 10, (1991-92), págs. 365-370, con estudio lingüístico en UNTERMANN, J.: «Comentario a la inscripción musiva de Andelos», TAN, 11, (1993-94), págs. 127-128.

68 Mezquíriz, M. a A.: Pompelo. Il. Pamplona, 1978, págs. 22-25; y «Descubrimiento de pavimentos de 'opus signinum' en Cascante (Navarra)», en Homenaje a D. José Esteban Uranga. Pamplona, 1971, págs. 227-307, esp. Pág. 292.

69 VelAZA, J.: op. Cit. (n. 55), págs. 211-25 y «La evolución de la ciudad romana de Andelo a la luz de los testimonios epigráficos", en Rodríguez Colmenero, A. (ed.): Los orígenes de la ciudad en el Noroeste Hispánico. Lugo, 1998, págs. 623-642, esp. Pág. 630 para el caso de Andelo, una de las ciuitates vásconas más generosas en cuanto a la conservación de su registro epigráfico.

70 Mezquíriz, M. ${ }^{a}$ A.: Pompelo..., págs. 18-19.

71 En este caso, como documentan HERNÁNDEZ VERA, J. A., y CASADO, P.: «Graccurris: la primera fundación romana en el valle del Ebro», en Symposion de Ciudades Augusteas. II. Zaragoza, 1976, págs. 23-29, esp. Pág. 24, a una fase de la Edad del Hierro I —caracterizada por la cerámica a mano con digitaciones y ungulaciones - le sucede, inmediatamente, una segunda fase - acorde con lo que las fuentes clásicas transmiten sobre la fundación de esta ciudad en el eje del Ebro- con materiales republicanos que coinciden, además, con una notable expansión del asentamiento, vinculada sin duda a sus propósitos estratégicos, que han sido destacados por DupRÉ, N.: «La place de la Vallée de l'Ebre dans I’Espagen Romaine», MCV, 9, (1973), págs. 133-176, esp. Pág. 148.

72 Mezquíriz, M. ${ }^{a}$ A.: «Primera campaña de excavaciones en Santacara (Navarra)», PV, 138-139, (1975), págs. 83-108, esp. Pág. 109 y, con especial atención al repertorio cerámico al que nos venimos refiriendo en Cerámica prerromana..., pág. 599.

73 Como se ha apuntado (véase nota 65), el material cerámico prerromano y romano republicano (Campaniense A de hacia el 300 a. C.) recogido en las labores de desescombro previas a la excavación de la termas de Los Bañales por A. Beltrán (BELTRÁN MARTínEZ, A.: «Las termas de Los Bañales», en BELtrán Martínez, A. (dir.): Atlas de Prehistoria y Arqueología Aragonesas. I. Zaragoza, 1980, págs. 192193) sólo pudo ser interpretado por AguARod, M. ${ }^{a}$ C.: op. Cit. (n. 65), pág. 987 como resultado de la colmatación y relleno del espacio termal del yacimiento fruto de los arrastres de material desde el cercano cerro del Pueyo, en cuya ladera Sur se levantan, todavía hoy, las ruinas del referido complejo recreativo.

74 Ona, J. L., Paz, J., Pérez, J. A., y De Sus, M. ${ }^{a}$ L.: op. Cit. (n. 8), págs. 11-13 con testimonios de Campaniense A de la segunda mitad del siglo II a. C. en convivencia con cerámicas de técnica ibérica, cerámicas a torno y cerámica decorada en tonos ocre.

${ }^{75} \mathrm{Al}$ margen de las recientes noticias sobre el posible campamento de invierno de Pompeyo en el solar de los Vascones que ARMENDÁRIZ, J.: Propuesta de identificación..., págs. 48-49 ha puesto en relación con la colección de glandes inscriptae procedentes del entorno de Pompelo, recientemente puestos en contexto por DÍAZ, B.: “Glandes inscriptae de la Península Ibérica», ZPE, 153, (2005), págs. 219-236, esp. Págs. 233-235, n. ${ }^{\circ} \mathrm{S} 14-17$, existen noticias (LABEAGA, J. C.: «Carta arqueológica del término muni 
Respecto de la progresiva incorporación por parte de las ciuitates de los Vascones en los hábitos urbanísticos romanos - no sólo a nivel monumental, como refieren las fuentes en un conocido pasaje de Tácito referente a los Britanos ${ }^{76}$, sino también urbanístico, con una evidente adaptación del antiguo trazado urbano prerromano a los requerimientos de las nuevas formas de vida ${ }^{77}$ - el propio catálogo de obras públicas que recogemos en la Tabla I sería una buena muestra de ello. Igualmente, serían buen ejemplo de este fenómeno el traslado al llano - y consiguiente dotación de un trazado urbanístico ortogonal típicamente romano- documentado en el siglo I a. C., por ejemplo, para los casos de Andelo, Pompelo, presumiblemente Cascantum - desde el vecino poblado del Cabezo de la Mesa de Ablitas-, Cara - desde el montículo de las Escuelas Municipales, que dominaba el valle del río Aragón- o Calagurris donde —al margen del presumible aporte de población de poblados del entorno- se mantuvo su situación en el cerro volcado al río Cidacos pero adaptando ésta a los patrones urbanísticos romanos ${ }^{78}$ pero también en la época Flavia, con seguridad, para el caso de Tarraca ${ }^{79}$. Dichos momentos -como tendremos oportunidad de ver-constituyen dos de los hitos cronológicos básicos en la integración de estos territorios en los hábitos constructivos romanos y en la forja de lo que F. Burillo ${ }^{80}$ ha venido a llamar las "ciudades en llano»: el momento posterior a la fundación de Pompelo y, por supuesto, la época Flavia, que, como se está revelando a medida que avanza nuestro conocimiento

cipal de Sangüesa», TAN, 6, (1987), págs. 7-116, esp. Págs. 21-25) sobre otro posible establecimiento castrense en Sangüesa, el de "Los Cascajos", que fuera excavado por RAmos, M.: «El campamento de 'Los Cascajos' (Sangüesa). 1. ${ }^{a}$ Campaña de Excavación, 1989», TAN, 10, (1991-92), págs. 426-427. A nuestro juicio -y como ha apuntado NúÑEZ, J.: op. Cit. (n. 12), pág. 119- pese a su posición estratégica faltan datos arqueológicos que aseguren su identificación como recinto fortificado de carácter militar al tiempo que la cronología de sus materiales - siglo I a. C.: de tipo celtibérico y, después, del siglo II d. C.: netamente romanos - no termina de aclarar a qué episodio de la conquista - cerrada en época temprana para esta zona - podría adscribirse. Sin cerrar queda aun la posibilidad — planteada por GARCíA MoRÁ, F.: Un episodio de la Hispania republicana: la guerra de Sertorio: planteamientos iniciales. Granada, 1991, págs. 407-422 y para la que han buscado bases arqueológicas PINA, F., y PÉREZ, J. A.: «EI oppidum Castra Aelia y las campañas de Sertorius en los años 77-76 a. C.», JRA, 11, (1998), págs. 245264- de que el castra Aelia de las fuentes deba buscarse en el entorno de Alaun o mejor aguas abajo del Ebro, en el área de La Cabañeta del Burgo de Ebro (FerReruela, A., y Mínguez, J. A.: «Un nuevo descubrimiento epigráfico romanorrepublicano en el valle del Ebro", en NAVARRO, M. y Demougin, S. (eds.): Élites Hispaniques. Burdeos, 2001, págs. 241-249, esp. Págs. 246-248).

76 TAC., Agr. XXI, 1, en el que Agrícola insta a los Britanni ut templa, fora, domos extruerent.

77 Mezquíriz, M. ${ }^{a}$ A.: op. Cit. (n. 10), pág. 441.

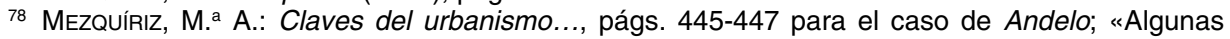
aportaciones al urbanismo de Pompelo", en Symposion de Ciudades Augusteas. Zaragoza, 1976, págs. 189-194, esp. Pág. 191 para el de Pompelo, en la que hacia el 60 a. C. los fondos de cabañas han sido sustituidos por viviendas de factura romana abiertas a una red viaria urbana que cada vez conocemos mejor; ARMENDÁRIZ, J.: El proceso de formación..., pág. 622 para el caso de Cascantum; MeZquíriz, M. ${ }^{a}$ A.: Primera campaña..., pág. 84 y, después, Magallón, M. ${ }^{a}$ A.: op. Cit. (n. 28), pág. 39 para el de Cara - donde la incorporación del urbanismo romano se traduce en la construcción de un indeterminado edificio público anterior al cambio de Era pero después reutilizado en el fecha más tardía-; y GómEzPANTOJA, J.: «La ciudad romana de Calahorra», en Symposion de Ciudades Augusteas. II. Zaragoza, 1976, págs. 185-188, pág. 185.

79 ANDREU, J.: «Incidencia de la municipalización flavia en el conuentus Caesaraugustanus», Salduie, 3, (2003), págs. 163-185, esp. Pág. 177.

80 BURILlo, F.: Aproximación diacrónica a las ciudades antiguas del valle Medio del Ebro. Teruel, 1986. 
de la documentación, debió ser uno de los momentos de mayor efervescencia edilicia en las comunidades urbanas de la Hispania romana ${ }^{81}$.

Para la época Flavia —como ha puntualizado F. Beltrán Lloris para el valle del Ebro82 - la mayor parte de las ciuitates de nuestro territorio - presumiblemente en parte gracias al desembolso de sus notables, fenómeno, como veremos, no todo lo documentado que sería deseable en el territorio vascón- casi todos los centros urbanos cuentan ya con activas elites municipales que manifiestan su prestigio a través de sus monumentos funerarios, una muestra más de su integración en la mentalidad romana y, si se quiere, también reflejo de una suerte de actuación evergética que, si bien no redundaba en el espacio urbano sí lo hacía en el del territorium $^{83}$ y muchas veces, como en algunos de los casos que más adelante estudiaremos, en puntos de tanto potencial propagandístico como las uiae de acceso a las distintas comunidades. Así los monumentos funerarios de época Flavia -mejor que Antonina- de los Atilii de Sádaba y Sofuentes (Zaragoza ${ }^{84}$ ) -el primero al pie de la uia Caesaraugusta-Pompelo ${ }^{85}$-, o de los Aemilii de la ermita de Nuestra Señora de Andión (Navarra ${ }^{86}$ ) son una muestra más - a la que se añadirían los igualmente monumentales conjuntos funerarios de Santa Elena de Oiasso y del entorno de Santacrís de Eslava ${ }^{87}$ - de cómo entrado ya el siglo II d. C. la mayor par-

81 Como síntesis puede verse: Merse, W. E.: Temples and Towns in Roman Iberia. The Social and Architectural Dynamics of Sanctuary Designs from the Third Century B. C. to the Third Century A. D. Berkeley-Los Ángeles-Londres, 1999, págs. 204-267 y, a partir de la documentación arqueológica NüNNERICH-Asnus, A.: El arco cuadrifronte de Cáparra (Cáceres). Un estudio sobre la arquitectura flavia en la Península Ibérica. Madrid, 1996.

82 Beltrán Lloris, F., Martín Bueno, M., y Pina, F.: Roma en la Cuenca Media del Ebro. La Romanización en Aragón. Zaragoza, 2000, págs. 92-106.

83 Sobre la dimensión de autorepresentación de los notables inherente a este tipo de complejos funerarios puede verse: CANCELA, M. ${ }^{a}$ L.: «Los monumentos funerarios de las elites locales hispanas», en Navarro, M., y Demougin, S. (eds.): op. Cit. (n. 75), págs. 105-120, esp. Págs. 106-107.

${ }^{84}$ La cronología antonina del Mausoleo de los Atilios fue defendida, a partir de su ornamentación, por MenÉndez Pídal, R.: «El Mausoleo de los Atilios», AEA, 43, (1970), págs. 89-112, esp. Págs. 110-111. Sin embargo, últimamente CANCELA, M. ${ }^{a}$ L.: «Las corrientes clásicas en la arquitectura funeraria romana», en LAcARRA, C. (ed.): op. Cit. (n. 13), págs. 237-264, esp. Pág. 257 ha rebajado la cronología a la época flavia lo que, por otra parte, encaja mejor con la condición de adscritos a la Quirina tribus de los homenajeados en dicho sepulcro (CIL, II, 2973 de Sádaba). La datación flavia del monumental conjunto epigráfico-escultórico (CIL, II, 2974) de Sofuentes puede seguirse en FATÁs, G., y MARTín BuENO, M.: «Un mausoleo de época imperial en Sofuentes (Zaragoza)», MM, 18, (1977), págs. 232-271, pág. 269.

85 Aguarod, M.a C., y Lostal, J.: op. Cit. (n. 51), págs. 167-218, esp. Pág. 211.

86 VelazA, J.: op. Cit. (n. 68), pág. 635, aunque se decanta por un carácter honorífico de los epígrafes CIL, II, 2966 y 2967 del que no estamos muy convencidos como tendremos oportunidad de comentar más adelante.

87 El conjunto funerario documentado en Santa Elena, en Irún, puede fecharse en época Flavia a juzgar por la presencia de vidrio de dicha época en el ajuar que acompañaba las urnas de incineración (BARandiarán, I., Martín Bueno, M., y Rodríguez Salís, J.: «Necrópolis de Santa Elena, Irún (Guipúzcoa), 1973)», NAH, 5, (1977), págs. 269-274 y CANCELA, M. a L., y MARTín BuENO, M.: «Relazioni tra i monumenti funerari nord-africani e alcuni esempli spagnoli in epoca imperiale romana», L 'Africa Romana VIII. Cagliari, 1990, págs. 101-105. Presumiblemente de finales del siglo I o comienzos del II d. C. son los conjuntos funerarios de Santacrís, no sólo el conjunto de incineración que ya referimos con anterioridad (ARmendÁRiz, R., Mateo, M. ${ }^{a}$ R., SÁez de Albéniz, M. ${ }^{a}$ P.: op. Cit. (n. 47), págs. 831-835) sino también el que constituirían los materiales localizados en el entorno de la Ermita de San Juan de Gallipienzo, conocidos popularmente como «Los Casquilletes de San Juan» y que ya TARACENA, B., y VÁzQUEZ DE PARGA, L.: 
te de las ciudades de los Vascones alcanza su máximo esplendor tanto en extensión, como en infraestructuras, como en ornamentación de sus espacios públicos y privados. Así, para esta centuria nos consta que Andelo se extiende ya por un territorio aproximado de casi $20 \mathrm{Ha}^{88}$, que Pompelo ha reestructurado su espacio forense incorporando un macellum y presumiblemente disfruta ya de unas termas ${ }^{89}$, que Calagurris se monumentaliza notablemente con viviendas como la suntuosa excavada en el solar de «La Clínica ${ }^{90}$ », o que el foro de Tarraca está ya entonces plenamente configurado de acuerdo con los modelos arquitectónicos de la época ${ }^{91}$. Y, como reverso de la misma realidad que venimos describiendo, es éste también el momento de florecimiento de conjuntos rústicos y uillae como los de Campo Real o Liédena -en el territorium de los Iluberitani-, Sofuentes - quizás en el de Nemanturista-, Las Vegas del Ebro —en el de Gracchurris- o Arellano ${ }^{92}$-en el de los Andelonenses-. Estos ejemplos darían razón al séptimo de los puntos que anteriormente enumeramos respecto de los rasgos generales que sobre de las ciudades de los Vascones pueden inferirse de la documentación arqueológica.

Por su parte, no falta documentación arqueológica en el antiguo solar vascón sobre la transformación - cuando no regresión- del poblamiento urbano a partir de los siglos III d. C. y especialmente IV d. C. En esta época, por ejemplo, parece que se abandonan algunas viviendas de Andelo como la decorada con un mosaico de opus tessellatum con representación de $\mathrm{Pan}^{93}$; se registran los primeros niveles de destrucción y cenizas en la estratigrafía de Pompelo así como la amortización para nuevos usos de antiguos espacios urbanos ${ }^{94}$, como también están

«Excavaciones en Navarra. III. Prospecciones en 'El Castellar' de Javier y 'Los Casquilletes de San Juan` de Gallipienzo», PV, 24, (1946), págs. 9-27, esp. Págs. 16-24 y después BlázQUEZ, J. M. a.: «Relieves de los 'Casquilletes de San Juan', Gallipienzo», PV, 84-85, (1961), págs. 121-126, esp. Pág, 121 consideraron procedentes del entorno de Santacrís de Eslava.

${ }^{88}$ Mezquíriz, M. a A.: Andelos: secuencia estratigráfica..., pág. 517.

89 Mezquíriz, M. ${ }^{a}$ A.: «Pamplona, ciudad romana», Rev. Arq., 30, (1983), págs. 26-33, esp. Pág. 29

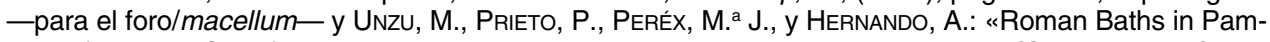
plona (Navarra, Spain)", en Babels. Anual Papers on Mediterranean Archaeology. 'Cura Aquarum'. Leiden, 2006, págs. 441-445, esp. Pág. 445.

${ }_{90}$ EsPINOSA, U.: op. Cit. (n. 8), págs. 134-137.

91 JIMÉNEZ, J. L.: Arquitectura forense en la Hispania Romana. Zaragoza, 1987, págs. 100-101.

92 Sobre Campo Real: Marcos Pous, A., y CASTIELLA, A.: «Prospecciones en Campo Real (límite navarro-aragonés)", Cuadernos de Trabajo de Historia. I. Pamplona, 1974, págs. 104-136, esp. Pág. 135. La cronología de Liédena puede estudiarse en: TARACENA, B.: «La villa romana de Liédena. I», PV, 36, (1949), págs. 353-382 y «La villa romana de Liédena. Il», PV, 38-39, (1950), págs. 9-40. Para Sofuentes véase BELTRÁN LLORIS, M.: «Roma: República y Alto Imperio», en Estado Actual de la Arqueología en Aragón. I. Ponencias. Zaragoza, 1990, págs. 215-262, esp. Pág. 253 y BeLtRán LLoRIS, F., MARTín Bueno, M., y PINA, F.: op. Cit. (n. 82), págs. 163-164. Para el poblamiento rural del entorno de Gracchurris, véase: HeRnández VerA, J. A.: op. Cit. (n. 8), pág. 182. El caso de Arellano, de forma sintética en MezquíRIZ, M. ${ }^{\text {a A.: } ~ « L a ~ v i l l a ~ d e ~ A r e l l a n o: ~ e l ~ p o b l a m i e n t o ~ r u r a l ~ d e ~ e ́ p o c a ~ r o m a n a ~ e n ~ N a v a r r a », ~ e n ~ A N D R E U, ~}$ J. (ed.): op. Cit. (n. 2), págs. 245-262.

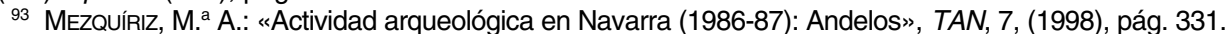

${ }_{94}$ Mezquíriz, M. ${ }^{a}$ A.: Algunas aportaciones..., pág. 192. Esta coyuntura -tradicionalmente vinculada a las invasiones de los Francos- se conocerá mejor cuando se publiquen los hallazgos de lienzos de muralla con materiales arquitectónicos y epigráficos de relleno del siglo III d. C. a los que aludió Javier Velaza en el transcurso de su intervención sobre "Grecia y Roma: civilizaciones urbanas» el día 13 de marzo de 2006 en el marco del ciclo de conferencias La ciudad en la Antigüedad, organizado por el Cen- 
atestiguados niveles de incendio para dicha fecha en Cascantum $^{95}$; y se abandona el poblamiento del núcleo pirenaico de lacca ${ }^{96}$.

Por último y si, como dijimos, la ciudad antigua $-\mathrm{y}$, como tal, también la romana- es, sobre todo, un espacio de intercambio, comercio y producción, la documentación arqueológica procedente de las ciuitates del solar vascón nos ha permitido identificar la dedicación metalúrgica de establecimientos como Andelo o Santacrís ${ }^{97}$ así como el extraordinario tráfico que -en el paso del siglo I al II d. C.- debió vivir el puerto cantábrico de Oiasso ${ }^{98}$, para el que en esta época incluso se rehace su muelle ${ }^{99}$.

\section{2 .}

Generalmente, la documentación epigráfica viene en auxilio de quienes trabajamos sobre la Antigüedad para esclarecer aspectos no sólo sobre los usos lingüísticos u onomásticos de una época concreta sino, especialmente, para el conocimiento de los ritmos de monumentalización de las ciudades y, por supuesto, del paisaje epigráfico que debió caracterizarlas. La epigrafía del antiguo solar de los Vascones - pródiga en datos sobre cuestiones como el mundo funerario, religioso, votivo y onomástico ${ }^{100} \mathrm{o}$ en información sobre aspectos lin-

tro Asociado de la UNED de Tudela (Navarra), aunque, en esencia, ya se había contactado con parte de ellos en Mezquíriz, M. ${ }^{a}$ A.: La excavación estratigráfica de Pompelo. I. Campaña de 1956. Pamplona, 1958, pág. 220. Sobre el fenómeno de la alteración urbanística de Pompelo en época tardoantigua, puede verse MEzQuíriz, M. ${ }^{a}$ A., y TABAR, I.: «Excavaciones arqueológicas en la Catedral de Pamplona», TAN, 11, (1993-94), págs. 310-311, esp. Pág. 312.

${ }_{95}$ MezquíRIz, M. ${ }^{a}$ A.: «Recientes hallazgos de Arqueología romana en Navarra», ED, 20, (1972), págs. 265-281, esp. Pág. 267.

${ }^{96}$ Ona, J. L., Paz, J., Pérez, J. A., y De Sus, M. ${ }^{a}$ L.: op. Cit. (n. 8), pág. 33.

${ }_{97}$ Para VelazA, J.: op. Cit. (n. 68), pág. 630 el floruit de Andelo en la primera mitad del siglo I d. C. debe ponerse en relación con la consolidación de su actividad metalúrgica, dedicación económica ésta que conocemos bien para la época romana en Navarra como han estudiado TABAR, I, y UNZU, M.: «Cuencas mineras en época romana: Lanz», TAN, 5, (1986), págs. 262-278 y SÁNCHEZ, A. C.: «La Real Fábrica de Orbaiceta (Navarra). Arqueología industrial y campos de trabajo, 1986-1991», TAN, 12, (2001), págs. 269-295. La posible vinculación de la ciuitas ubicada en Santacrís con las minas de cobre de Artamaleta ha sido defendida por Castiella, A.: Por los caminos romanos..., pág. 101.

${ }_{98}$ Sobre el apogeo de Oiasso en época Flavia, véase, de forma monográfica FERNÁNDEZ OCHOA, C, y Morillo, A.: op. Cit. (n. 8), págs. 181 y 187-188.

${ }_{99}$ Efectivamente, a finales del siglo I y comienzos del II d. C. se recompuso el muelle de Oiasso a través de una construcción de vigas de madera con somera pavimentación de losetas de piedra (LÓPEZ, M.: “Calle Santiago (Irún)», Arkeoikuska, 93, (1994), págs. 343-348 y GEREÑu, M., LóPEZ, M., y URTEAGA, M. ${ }^{a}$ M.: «Novedades de arqueología romana en Irún-Oiasso. 1992-96», Isturitz, 8, (1997), págs. 467-489, esp. Págs. 471-476), para la que NúÑEZ, J.: op. Cit. (n. 12), pág. 127 ha querido ver paralelos en el puerto de Londinium.

${ }_{100}$ MARCo, F.: «Las estelas decoradas de los conventos Caesaraugustano y Cluniense», Caesaraugusta, 43-44, (1978), págs. 191-199; «Las estelas decoradas de época romana en Navarra», TAN, 1, (1979), págs. 205-250 — para el mundo funerario_; «¿Taurobolios vascónicos? La vitalidad pagana en la Tarraconense durante la segunda mitad del siglo IV», Gerión, 15, (1987), págs. 208-319 —para el religioso-; y CASTILLO, C.: «La onomástica en las inscripciones romanas de Navarra», en Segundo Congreso General de Historia de Navarra (Príncipe de Viana, Anejo 14). Pamplona, 1992, págs. 117-133 u “Onomástica personal en las inscripciones romanas de Navarra», CUAUN, 5, (1997), págs. 127-144; RAmíREZ SÁdABA, J. L.: «La onomástica de los vascones. Autóctonos e inmigrantes», PV, 14, (1992), pp. 287293; y «Navarra: los colectivos sociales de la Antigüedad», en V Congreso de Historia de Navarra: Gru- 
güísticos ${ }^{101}$ - ha sido, sin embargo, poco generosa en testimonios alusivos no sólo a procesos de monumentalización sino también a las instituciones y órganos de gestión municipal que, a juzgar por las prerrogativas que a ellas concede la legislación municipal ${ }^{102}$, debieron participar en la promoción y mantenimiento de dichas obras públicas.

Así, en el territorio vascón y gracias a la documentación epigráfica ${ }^{103}$ sólo conocemos a los aediles Sempronius Carus Siluini f(ilius) y Lucretius Martialis Lucreti f(ilius) de una conocida placa de bronce de Andelo104; a los Iluiri Pompe[I(onenses)], al patronus P(ublius) Sempronius Taurinus Dam[a]nitanus y a los notables de cargo indeterminado Claudius Quartinus, Sergius Crescens, T(itus) Antonius Paternus y [L(ucius)] Caecilius Aestiuus de las perdidas placas de Arre de Pompelo ${ }^{105}$; al dispensator publicus Athenion de Eslava ${ }^{106}$; a la flaminica provincial Sempronia Fusci f(ilia) Placida de origo Pompelonensis, a su marido, $C$. Cornelius Valens, encargado de una legatio censualis, al también flamen provincial - y antes Iluir seguramente en Pompelo- Cn. Pompeius Pompelonensis, al también sacerdote provincial $C$ (aius) Sempronius Fidus Calagorrit(anus) y a la flaminica Postumia Nepotiana, Karensis, personajes todos ellos documentados en Tarraco donde debieron culminar una carrera política que, sin duda, debió dar sus primeros pasos en sus comunidades vásconas de origen ${ }^{107}$; y a los lluiri C(aius)

pos sociales en Navarra. Relaciones y derechos a lo largo de la historia. Pamplona, 2002, págs. 21-53 - para las cuestiones onomásticas-.

101 Especialmente VELAZA, J.: Epigrafía y dominios lingüísticos..., págs. 209-218 y GoRROCHATEGUI, J.: «Las raíces lingüísticas de Navarra», en JiMENO, R., y LóPEZ-MuGARTZA, J. C. (eds.): Vascuence y Romance: Ebro-Garona, un espacio de comunicación. Pamplona, 2004, págs. 105-122 o bien "Onomástica vascónica y aquitana: elementos para el conocimiento de la Historia Antigua de Navarra", en ANDREU, J. (ed.): op. Cit. (n. 2), págs. 111-136.

102 Por ejemplo, Lex Irnitana XVIII y XIX (sobre el papel de los aediles y lluiri municipales); LXII (sobre la restauración de edificios); LXXIX (sobre la administración de la pecunia publica respecto de las obras públicas), o LXXXI (sobre la construcción de obras de saneamiento) con los oportunos comentarios en MENTXAKA, R.: El Senado municipal de la Bética hispanorromana a la luz de la lex Irnitana. Vitoria, 1993, págs. 136-149. Como síntesis sobre las distintas instancias que, a juzgar por la documentación epigráfica, intervinieron en la construcción pública de los municipios hispanos véase MELCHOR, E.: «La construcción pública en Hispania: iniciativa imperial, municipal y privada», MHA, 13, (1992-93), págs. 129-170 y -enmarcado precisamente en el contexto de los términos de la lex - NAVARRO, M.: «Les dépenses publiques des notables des cités en Hispanie Citerior sous le Haut-Empire», REA, 99, (1997), págs. 109140. Para cuestiones conceptuales generales y particulares alusivas a otros territorios del mundo romano, son de gran utilidad los trabajos recogidos en MAYER, M., y Miró, M. (eds.): Homenatge a F. Giunta. Commitenza e committenti tra Antichità e Alto Medioevo. Barcelona, 1996; Chastagnol, A., Demougin, S., y LePELLEY, C. (eds.): Splendidissima Ciuitas. Études d'Histoire Romaine em homage á François Jacques. París, 1996; y Christol, M., y MAsson, O. (eds.): Actes du Xe Congrès International d'Epigraphie Grecque et Latine. Nîmes, 4-9 octobre 1992. París, 1997.

103 Para los datos procedentes de la información numismática remitimos aquí a BELTRÁN LLORIS, F.: «Los magistrados monetales en Hispania», Numisma, 150-155, (1978), págs. 169-212, esp. Págs. 193-205.

${ }_{104} \mathrm{AE}, 1989,486$, con comentario y noticia del hallazgo en MezQuírIZ, M. ${ }^{a}$ A.: «Placa de bronce con inscripción procedente de Andelo", TAN, 4, (1985), págs. 185-186.

105 CIL, II, 2958-2960, con estudio en SAYAS, J. J.: Los vascos en la Antigüedad. Madrid, 1994, pp. 79-117.

106 IRMN, 67. Sus funciones han sido tratadas por OzCÁRIZ, P.: «El papel del territorio navarro en la administración de la Prouincia Hispania Citerior durante el Alto Imperio", en ANDREU, J. (ed.): op. Cit. (n. 2), págs. 167-178, esp. Pág. 172.

107 CIL, II, 4246 y RIT, 327 para los dos primeros casos y CIL, II, 4234=RIT, 297 para el tercero; CIL, II, 4242, para la flaminica originaria de Cara y CIL, II, 4245 para el flamen Calagorri(tanus). Para los sa- 
Sempronius Auitus y L(ucius) Aemilius Patinus del conocido vaso de los circienses de Calagurris ${ }^{108}$.

Respecto de las inscripciones que documentan episodios de construcción pública o de monumentalización en las ciuitates de los Vascones la nómina queda reducida a la placa de bronce de Andelo - antes referida - que debió formar parte de la ornamentación de un templo dedicado a Apollo Augustus por los aediles arriba mencionados ${ }^{109}$; a una fragmentada lápida de mármol procedente de Gracchurris con la fórmula nomin[e - - / impens[a sua --] que, a juicio de U. Espinosa ${ }^{110}$ puede estar documentando alguna dádiva de un notable -quizás un Seuerus a juzgar por el nomen que puede leerse en la tercera línea del epígrafe- al municipio Gracchurritano; a una placa de arenisca conservada en el Museo Municipal de Calahorra que debió formar parte de algún monumento público estatuario quizás erigido en el circo de Calagurris en época de Marco Aurelio'111; a otra perdida procedente también de dicha ciudad y que puede estar documentando una dedicación por parte del mu]ni[c(ipium)_-] a algún emperador ${ }^{112}$; y al excepcional documento en bronce que testimonia la regulación de un riuus Hiberiensis que surcaría parte del sector meridional del solar vascón en época de Adriano ${ }^{113}$. Por su parte, para las inscripciones con mención a Calpurnia Vrchatetel, a su hijo L. Aemilius Seranus, a su esposa [C]orn[e]lia [F]laua, y al hijo de ambos, también L. Aemilius Seranus, procedentes de Andelo ${ }^{114}$ y para las que no hace mucho $\mathrm{J}$. Velaza ${ }^{115}$ ha supuesto un carácter honorífico y un lugar original en espacio público creemos que - por sus fórmulas y por la ausencia de men-

cerdotes del culto imperial puede verse: SAYAS, J. J.: «El culto al emperador entre las gentes vasconas», ETF (II), 4, (1989), págs. 437-445. Para el caso del censualis, SAYAS, J. J.: «Ad census accipiendos de ciudades vasconas y várdulas y la legatio censualis de un pamplonés», ETF (II), 2, (1989), págs. 137152.

${ }^{108}$ AE, 1998, 777 e HEp7, 589. Sobre él puede verse MAYER, M.: «Propuesta de lectura para el vaso de los circenses del alfar de La Maja», Kalakorikos, 3, (1998), págs. 187-192, esp. Pág. 188.

109 Véase nota 104. Para la inserción de la noticia en el proceso de monumentalización de Andelo puede verse VelAZA, J.: op. Cit. (n. 68), pág. 637.

110 EspinosA, U.: Epigrafía Romana de La Rioja. Logroño, 1986, n. ${ }^{\circ}$ e HEp1, 495.

111 Se trata de HEp10, 420, sobre la que puede verse un estudio en JORDÁN, A.: «Un homenaje a Marco Aurelio y Lucio Vero procedente de Calahorra», en RodríGUEz NEILA, J. F., y MELCHOR, E. (eds.): Poder Central y Autonomía Municipal: La Proyección Pública de las Élites Hispanorromanas. Córdoba, (en prensa), s. págs. Para este epigrafista, es plausible pensar que otra inscripción del conjunto epigráfico calagurritano (HEp7, 578), procedente, además, del entorno del circo (CINCA, J. L.: «La necrópolis del Cascajo y la pared sur del circo romano: dos nuevas destrucciones arqueológicas», Kalakorikos, 1, (1996), págs. 45-55, esp. Pág. 51) pudiera estar atestiguando el acto munificente de un Aemil[ius?] en el contexto de dicho edificio. Recuérdese, que, efectivamente, la participación de los particulares en el pago de parte de este tipo de construcciones - podia, subsellia, porticus...etc.- está bien atestiguado en el corpus epigráfico peninsular relativo al comportamiento munificente de las élites. Al respecto, por ejemplo, véase AndReU, J.: Munificencia pública en la provincia Lusitania (ss. I-IV d. C.). Zaragoza, 2004, pág.s. 77-81, esp. Pág. 79, n. 134.

112 Espinosa, U.: op. Cit. (n. 110), n. ${ }^{\circ}$ 5=HEp1, 497

113 BeLtRÁN LloRIS, F.: «An irrigation decree from Roman Spain: the Lex riui Hiberiensis», JRS, 96, (2006), págs. 147-197 y, como avance «Irrigación y ordenación del territorio en la antigua Cascantum: el testimonio de la lex riui Hiberiensis», en ANDREU, J. (ed.): op. Cit. (n. 67), págs. 229-244.

114 CIL, II, 2966-2967 y AE, 1989, 459.

115 VelazA, J.: op. Cit. (n. 68), pág. 635. 
ciones a la autorización decurional — encaja mejor una funcionalidad funeraria o, cuando menos, nos parece no debe dudarse de su presencia en un ámbito privado, por mas que éste, efectivamente —como apuntamos más arriba-pudiera ser también ostentatorio del poder del grupo familiar de dedicantes y homenajeados en las mismas.

\section{3.}

Por último, en nuestro estudio de los parámetros en que se movió la monumentalización de las ciudades de los Vascones en época romana puede considerarse también de utilidad la documentación aportada por la estatuaria hallada en el solar de las comunidades que nos ocupan. El catálogo de piezas escultóricas procedentes del solar vascón - se conserven hoy en día o simplemente haya quedado noticia de sus hallazgos en la historiografía tradicional- es notable ${ }^{116}$, si

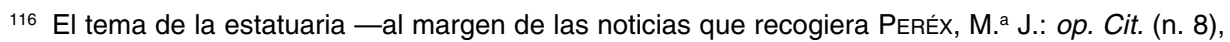
págs. 75-232 en su análisis de la documentación disponible para las comunidades de los Vascones y de los trabajos particulares sobre algunos de los hallazgos que a continuación se estudiarán- no ha sido abordado todavía con carácter general por la investigación sobre la Antigüedad en el territorio objeto de nuestro estudio de ahí que ofrezcamos a continuación un sucinto repertorio de dichos testimonios que ojalá pueda servir de punto de partida para ulteriores estudios sobre el tema:

a) Calagurris (9 piezas): cabeza de Júpiter del Museo Municipal (ELORZA, J. C.: Esculturas Romanas de La Rioja. Logroño, 1975, pág. 9 y EspinosA, U.: op. Cit. (n. 8), pág. 116); estatua de Afrodita en mármol blanco vestida con chiton (ElorzA, J. C.: op. Cit., pág. 12); cabeza de la «Dama de Calahorra» de apenas $21 \mathrm{cms}$., procedente de las excavaciones del Centro de Higiene (ELORZA, J. C.: op. Cit., págs. 10-16 y EspinosA, U.: op. Cit., pág. 128, sobre cuya cronología antoniniana ha vuelto recientemente KOPPEL, E. M.: «La decoración escultórica de las termas en Hispania», en IV Reunião sobre escultura Romana da Hispania. Madrid, 2004, págs. 339-366, esp. Pág. 345); una bellísima figura de bronce que debió ser remate de algún mueble de uso privado (ESPINOSA, U.: «Pequeña estatuilla romana de bronce hallada en la zona de Calahorra», $A E A, 50-51$, (1978), págs. 431-438); una supuesta cabeza de soldado; y un posible Cupido incompleto en mármol (sobre ellas véase MARTín BuENO, M., y CANCELA, M. ${ }^{a}$ L.: «Arqueología Clásica de Calahorra y su entorno", en Calahorra. Bimilenario de su fundación. Calahorra, 1984, págs. 77-91, esp. Pág. 80 y ElorzA, J. C.: op. Cit., págs. 28-29 y 23-26 respectivamente) y las perdidas estatuilla femenina de mármol blanco de $60 \mathrm{cms}$.; masculina en idéntico material y con $40 \mathrm{cms}$.; y estatua acéfala en alabastro aparecida en los años treinta.

b) Cara (2 piezas): calceus de bronce del Museo de Navarra (Mezquíriz, M. a A.: «Hallazgo de un 'calceus ' de bronce en Santacara», en Bronces y Religión Romana. Actas del XI Congreso Internacional de Bronces Antiguos. Madrid, 1993, págs. 301-302); y retrato de varón de 24 cms., fechado en época Julio Claudia (MezQuíRIz, M. ${ }^{a}$ A.: «Retrato masculino aparecido en las excavaciones de Santacara (Navarra)», PV, 137, (1974), págs. 403-405 y «Labor e incremento del Museo de Navarra: 1968-1975», PV, 144-145, (1976), págs. 305-327, esp. Pág. 317) del que es difícil determinar si se trataba de busto o estatua.

c) Curnonium (4 piezas): noticias de 1890 sobre el hallazgo de una pieza de escultura (pierna) y de un dedo de bronce (QuINTANILLA, E.: La Comisión de Monumentos Históricos y Artísticos de Navarra. Pamplona, 1995, pág. 318) así como de una pieza de mármol hallada en los años sesenta y vendida a un anticuario, hoy en paradero desconocido; y posible estatuilla de la diosa Diana (para ambas: ARMEndÁRIZ, J.: Bases arqueológicas..., pág. 105.

d) Gracchurris (1 pieza): talla de cabeza femenina en mármol blanco de tamaño natural fechable en la primera mitad del siglo I d. C. (EsPinosA, U., e IRIBARREN, B.: «Cabeza femenina de época romana descubierta en Alfaro (La Rioja)», Museos, 2, (1984), págs. 85-87). 
bien de éste sólo para algunas piezas podemos asegurar —o suponer con escaso margen de error - su presencia en espacios ornamentales públicos — por tanto de interés para el tema que nos ocupa en este trabajo- y no en ámbitos privados o de carácter doméstico. Ése sería, sin duda, el caso de las monumentales $-0,50 \mathrm{~m}$. y 1,20 m. de altura respectivamente- cabezas de Júpiter y estatua de Minerva pertenecientes — según propuesta de U. Espinosa - a alguno de los templos del municipio de Calagurris y fechadas en los siglos II y I d. C. respectivamente ${ }^{117}$; la estatua de bronce - de la que sólo se conservan pedestal y pies- fechada en el siglo I d. C. y que debió serlo de algún notable local, y el retrato masculino JulioClaudio hallados en uno de los supuestos edificios públicos de Cara ${ }^{118}$; y quizás, por el motivo, la estatua flavia de togado hallada en la C/Navarrería de Pamplona, solar de Pompelo ${ }^{119}$.

3.

Lógicamente, sólo un estudio pormenorizado de los testimonios arqueológicos que han sido recopilados en la Tabla I que se ofrece al final de este trabajo permite extraer conclusiones sobre el grado de monumentalización de las ciuitates que ve-

e) Pompelo (4 piezas): cabeza femenina de bronce hoy perdida procedente de la C/Curia (ALTADILL, J.: Geografía General del país Vasco-Navarro. Barcelona, s. a., pág. 669); estatua, también perdida, -mejor un togado (ELORZA, J. C.: «Dos notables esculturas del país Vasco-Navarro», $P V$,

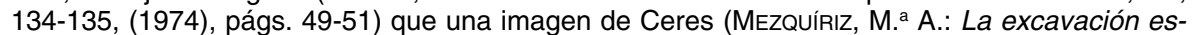
tratigráfica..., pág. 21) - hallada en 1895 en la C/Navarrería (ITURRALDE, J.: «Descubrimiento de antigüedades romanas en Pamplona», BCMNa, 8, (1895), págs. 177-180); una estatuilla de Mercurio con clámide de la que ya dio noticia Sandoval, P.: Catálogo de los Obispos que ha tenido la Santa Iglesia de Pamplona. Pamplona, 1614, págs. 3-4 y sobre la que volvieron MezQuíRIz, M. ${ }^{a}$ A.: op. Cit., pág. 21 y PERÉX, M. ${ }^{a}$ J.: op. Cit. (n. 8), págs. 204-206; y una mano de bronce de una escultura de notable tamaño que parece fue hallada, según MezQuíriz, M. ${ }^{a}$ A.: op. Cit., pág. 21 , en la C/Navarrería.

f) Tarraca (1 pieza): noticia del hallazgo de un «fragmento de estatua de mármol blanco varonil» en las faldas del cerro de El Pueyo (GALIAY, J.: op. Cit. (n. 65), pág. 82) hoy perdida.

Al catálogo de piezas de bulto redondo habría que añadir los relieves documentados en diversos cipos, capiteles y elementos constructivos procedentes del entorno de Santacrís (ARMENDÁRIZ, R., MATEO, M. ${ }^{a}$ R., y SÁEZ de AlBÉNIZ, M. ${ }^{a}$ P.: op. Cit. (n. 47), pág. 840 y, anteriormente, BLÁZqUEZ, J. M. ${ }^{a} .:$ op. Cit. (n. 89), pág. 126), los que adornaban los monumentales conjuntos sepulcrales de los Atilios de Sádaba (MENÉNDEZ PIDAL, R.: op. Cit. (n. 84), págs. 108-111) y Sofuentes (FATÁs, G., y MARTín Bueno, M.: op. Cit. (n. 82), págs. 239-243) así como el conjunto —-también presumiblemente flavio- de capiteles de Cara (MEZ-

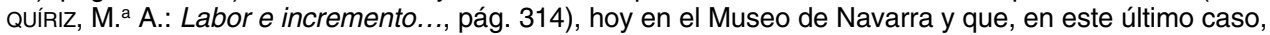
podrían ser vinculados a los programas edilicios que - recuperando motivos ornamentales típicos de la época Julio-Claudia - debieron emprender muchos municipios flavios hispanos (NüNNERICH-AsNUS, A.: «La ornamentación arquitectónica como exponente del prestigio de una urbe», en RODRíGUEZ COLMENERo, A. (ed.): op. Cit. (n. 69), págs. 219-248, esp. Págs. 241-247) al abrigo de la donación del Latium y de su conversión en municipios (ANDREU, J.: Edictum, municipium y lex: Hispania en época Flavia. Oxford, 2004, págs. 169-179).

117 EsPINOSA, U.: op. Cit. (n. 8), págs. 116 y 128-129 respectivamente y PeréX, M.a J.: op. Cit. (n. 8), pág. 112.

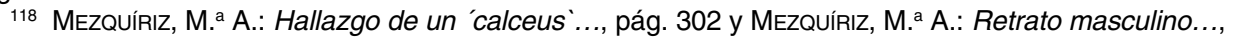

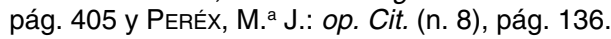

119 EloRzA, J. C.: op. Cit. (n. 116), pág. 50. 
nimos mencionando. Por ello, sin ánimo de exhaustividad —pues existe abundante bibliografía, a la que se remitirá si no ha habido, al respecto, sensibles novedades en la investigación- sí queremos detenernos a continuación en un análisis crítico -en el cuarto epígrafe del presente estudio lo llevaremos a cabo también desde una perspectiva diacrónica - de la tipología de la documentación disponible, agrupada en edificios forenses, cívicos y religiosos; edificios de espectáculos; obras hidráulicas; arquitectura doméstica; y necrópolis.

\section{1. Edificios forenses, cívicos y religiosos}

\section{1. 1. Obras de infraestructura defensiva y urbanística}

Tal como se desprende de nuestro cada vez mejor conocimiento de los oppida de los Vascones con los que Roma entra en contacto en los inicios de la conquista $^{120}$ y cuya situación - como vimos-apenas se altera sensiblemente al margen de puntuales traslados al llano, nos consta que aquéllos estaban, normalmente, fortificados. Sin embargo, las excavaciones arqueológicas en las ciuitates de los Vascones en época romana no parecen documentar con seguridad murallas de época Alto-Imperial excepto en Andelo y en $\mathrm{Cara}^{121}$, siendo de cronología tardoantigua las fortificaciones de Pompelo o de Calagurris ${ }^{122}$. En otros casos, como Gracchurris o Tarraca, su situación -especialmente en el caso de la primera, en un punto con condiciones de defensa naturales al estar flanqueado por diversos

120 La mejor síntesis puede verse en CASTIELLA, A.: «Peculiaridades del poblamiento prerromano en territorio vascón: Navarra», CUAUN, 12, (2004), págs. 177-233, esp., sobre la cuestión de las murallas, págs. 188-190.

121 Ambas de prestigio, según TaRacena, B., y VÁzquez de PARgA, L.: V. La Romanización..., pág. 424 y Mezquíriz, M. ${ }^{a}$ A.: Andelos: secuencia estratigráfica..., pág. 528 -para el caso de Andelo- y Primera campaña..., pág. 84 - para el de Cara—. Como puede verse en la Tabla I hay noticias arqueológicas ciertas de tramos de muralla en Santacrís (¿Nemanturista?): ARmendáRIZ, R. M.a., MATEO, M. ${ }^{a}$ R., y

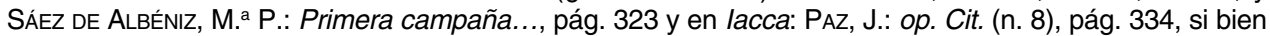
no se ha propuesto fecha para la primera y la segunda parece más de época ibérica sin que esté clara su reutilización en época Alto-Imperial. No entramos aquí en el caso del recinto amurallado de Olite (Jusué, C.: «Recinto amurallado de Olite», TAN, 4, (1985), págs. 227-247), seguramente la Ologicus de ISID., Hist. Goth., 63, sobre la que hemos tratado en otro lugar (ANDREU, J.: op. Cit. (n. 6), págs. 221-222). En cualquier caso, puede seguirse la polémica sobre la filiación altoimperial de este recinto en FERNÁNDEZ OCHOA, C., y MoRILLO, A.: «Fortificaciones urbanas de época bajo-imperial en Hispania. Una aproximación crítica», CuPAUAM, 18, (1991), págs. 267-299, esp. Pág. 287)

122 Sobre la muralla de Pompelo (durante un tiempo interpretada bien a partir de los restos musivos de la C/Curia, hoy en el Museo de Navarra -MezQuíRIZ, M. a A.: La excavación estratigráfica..., págs. 17, 219 y 227- bien a partir de la descripción de las mismas en la De laude Pampilone Epistula -TuDANCA, J. M.: Evolución socio-económica del Alto y Medio valle del Ebro en la época bajoimperial romana. Logroño, 1997, pág. 639, n. 23- véase, en este mismo trabajo, nota 94. El caso de Calagurris -para el que siguiendo a GutiÉRREZ, P.: «Calagurris Julia Nassica. Estudio de investigación de objetos arqueológicos», Berceo, 7, (1948), págs. 189-195, pág. 190 e Historia de la muy noble, antigua y leal ciudad de Calahorra. Logroño, 1956, págs. 63-65, ya fue apuntado un presunto trazado amurallado por GómEZ-PANTOJA, J.: op. Cit. (n. 78), págs. 186-187- parece ofrecer sólo datos fidedignos en los tramos amurallados detectados en el Camino de Bellavista y la C/Justo Aldea de la ciudad del Cidacos, estudiados por SÁENZ Preciado, J., y SÁenz Preciado, M. P.: «Excavaciones y consolidación del recinto amurallado de Calahorra», Estrato, 6, (1995), págs. 48-52. 
barrancos sobre el Alhama y el Cementerio y antiguo Matadero de Alfaro123 - y quizás - también de modo especial en el caso de Gracchurris- su rápida decadencia - constatada hacia finales del siglo II d. C. ${ }^{124}$, mucho antes de los primeros episodios de inestabilidad política registrados en el valle del Ebro- hicieron innecesaria la dotación de este tipo de construcciones.

\section{1. 2. Conjuntos forenses y monumentos asociados}

El foro es, sin duda, el centro cívico de las ciudades romanas. Su habitual pervivencia en los espacios institucionales futuros de las comunidades explica el mal estado en que nos ha llegado la información sobre éste en casos como el de Calagurris donde su situación apenas puede sino intuirse en el entorno de la actual Iglesia de Santiago - quizás pervivencia cristiana de un antiguo culto pagano-y de la Plaza de El Raso, todavía centro neurálgico de la Calahorra de hoy. Esta sugerente hipótesis — planteada ya por J. Gómez-Pantoja y argumentada por U. Espinosa ${ }^{125}$ - encuentra cierto predicamento no sólo en la impronta que su planta ha podido dejar en la actual urbanística calagurritana sino en el hallazgo en esa zona de materiales constructivos nobles, antefijas decoradas, algunos mosaicos y la conocida «Dama de Calahorra», a la que ya nos referimos ${ }^{126}$.

Sin noticias del mismo en Andelo ${ }^{127}$ y sólo inciertas —aunque bastante probables - por el edificio público de sillares almohadillados y profundos cimientos excavado en Cara y del que proceden diversos restos escultóricos y capiteles antes mencionados datables en el siglo i d. $\mathrm{C}^{128}$., los casos de Pompelo y de Tarraca parecen documentar muy bien la tipología de las construcciones forenses de época imperial. Así, tal como se manifiesta en ambos casos — dado que padecen una profunda reforma en época Flavia que sólo se ve culminada en el siglo ॥

123 Hernández Vera, J. A.: op. Cit. (n. 8), págs. 175-176.

124 Hernández Vera, J. A.: op. Cit. (n. 8), pág. 182.

125 Gómez Pantoja, J.: op. Cit. (n. 76), pág. 187 y, especialmente, Espinosa, U.: op. Cit. (n. 8), págs. 112-116.

126 Sobre estos hallazgos y su posible relación con el forum calagurritano, véase MARTín BuENO, M., y CANCELA, M. ${ }^{a}$ L.: op. Cit. (n. 114), pág. 88; y sobre la «Dama» en el contexto de la estatuaria recuperada en Calagurris veáse nota 116 , en este mismo trabajo.

127 Recientemente (especialmente en NúÑEZ, J.: op. Cit. (n. 12), pág. 125 y, a partir del estudio de paralelos en Termantia y Osca, en ARMENDÁRIZ, J.: El proceso de formación..., pág. 626, nota 22) ha sido criticada la interpretación como castellum aquae/fuente pública (MEZQUíRIZ, M. ${ }^{a}$ A., y UNZU, M.: «De hidráulica romana: el abastecimiento de agua a la ciudad romana de Andelos», TAN, 7, (1998), págs. 237266, esp. Págs. 258-265) del edificio construido sobre podium al Este del cardo de la ciudad, apuntándose que - por su situación, sus materiales e incluso su cronología - bien pudiera tratarse de un templo in antis, en cualquier caso al margen del conjunto forense de Andelo con el que todavía no se ha contactado. Para el caso de Andelo, sin embargo, sí contaríamos con la indiscutible noticia de un edificio religioso - si quiera se tratara de un sencillo sacellum - consagrado a Apolo por los aediles a partir de la conocida inscripción de bronce (AE, 1989, 486) descubierta lamentablemente, como es sabido, por la acción de los clandestinos y cuya datación, seguramente, como ha apuntado VeLAZA, J.: op. Cit. (n. 69), pág. 637 debe ser llevada a época Flavia mejor que a la de Trajano-Adriano propuesta por MEZQUíRIZ, M. ${ }^{a}$ A.: Placa de bronce..., pág. 186.

128 Sobre los referidos materiales escultóricos, véase nota 116. Sobre el edificio público en cuestión: Mezquírız, M. a A.: Primera campaña..., págs. 83-87 y 109. 
d. C. ${ }^{129}$ - los macella de Pompelo y Tarraca son fieles a las que J. L. Jiménez ${ }^{130}$ ha caracterizado como tendencias generales de la evolución constructiva de los espacios forenses en época Alto Imperial en las provincias occidentales, a saber, la separación de las áreas religiosas respecto de las cívicas de dicha área así como la generalización de edificios independientes para las funciones comerciales.

Así, en Pamplona se conoce un monumental edificio que, si bien fue inicialmente interpretado como un templo ${ }^{131}$, más tarde ha sido descrito ${ }^{132}$ como un macellum con patio porticado rectangular, tabernae y sacellum para las divinidades protectoras, macellum que, por otra parte, y siguiendo una de las tendencias arriba apuntadas para los foros hispanos imperiales, forma parte de un conjunto forense cuya área central debió ocupar la pequeña elevación sobre el río Arga que constituye el actual solar de la Catedral de Pamplona ${ }^{133}$ pero que debió abrirse a una amplia área recreativa ubicada en el entorno de la actual Plaza del Castillo donde, como es sabido, se han excavado las termas quizás mayores del Norte Peninsular ${ }^{134}$.

Peor conocido - pese a la oportunidad arqueológica que ofrece su privilegiada situación en un despoblado - es el foro de Los Bañales de Uncastillo, solar de la antigua Tarraca. A nuestro juicio - de acuerdo con lo que en su día plantearan tanto A. Beltrán Martínez como J. L. Jiméne $z^{135}$ - el conjunto de edificio porticado y estancias abiertas al mismo situado a la entrada del yacimiento encaja mejor como una plaza pública de funciones comerciales - quizás aterrazada- que como un área de habitación ${ }^{136}$, debiendo buscarse el resto de las edificaciones forenses - seguramente el templo- donde lo excavara J. Galiay ${ }^{137}$, en la ladera Sur del cerro de El Pueyo, lugar en el que aun son hoy visibles notables acumulaciones de basamentos de pedestales y de grandes pilares. En función de los vacíos que, a través de la fotografía aérea, pueden apreciarse en el núcleo habitacional de El

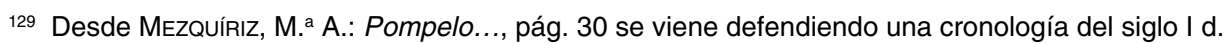
C. para la reorganización del conjunto forense de la supuesta capital de los Vascones, noticia sobre la que ha vuelto MARTín BuENo, M.: op. Cit. (n. 61), págs. 113-114 conectándola con la transformación urbanística de época Flavia que viven muchas comunidades hispanas y sobre la que luego volveremos. Por otra parte, para Tarraca, según BELTRÁN LLORIS, F.: El planteamiento urbano..., pág. 162 parece que los materiales apuntan a un apogeo de la construcción del espacio forense en el siglo II d. C.

130 JIMÉNEZ, J. L.: «Los modelos constructivos en la arquitectura forense de la Península lbérica», en Los Foros Romanos de las Provincias Occidentales. Madrid, 1987, págs. 173-177, esp. Págs. 175-176.

131 Mezquíriz, M. ${ }^{\text {a }}$ A.: Algunas aportaciones..., pág. 191.

132 Mezquíriz, M.a A.: Pompelo..., págs. 31-33 y Pamplona, ciudad..., pág. 29.

133 MezquíRIz, M. a A.: «Vestigios romanos en la Catedral y su entorno», en La Catedral de Pamplona. Pamplona, 1994, págs. 125-137, esp. Pág. 127.

134 Peréx, M. a J.: El poblamiento vascónico..., pág. 69, y, para las termas UnzU, M., Prieto, P., PERÉx, M. ${ }^{a}$ J., y HeRnando, A.: op. Cit. (n. 89), pág. 442.

135 JIMÉNEZ, J. L.: Arquitectura forense..., págs. 100-101. La posible interpretación como macellum del área de las columnas toscanas de Los Bañales la dio BELTRÁN MARTínEZ, A.: «Las obras hidráulicas de Los Bañales (Uncastillo, Zaragoza)», en Segovia. Simposium de Arqueología Romana. Barcelona, 1977, pág. 101 que incluso quiso ver una fuente en el centro de dicha área.

136 Así en Beltrán Lloris, F.: op. Cit. (n. 8), pág. 162.

137 Galiay, J.: op. Cit. (n. 65), pág. 82, noticias después comentadas por Beltrán Lloris, F.: op. Cit. (n. 8), pág. 161. 
Pueyo no debe descartarse tampoco la presencia de alguna plaza pública en la parte Norte de dicha área residencial, como en su día apuntara F. Beltrán Lloris ${ }^{138}$ aspectos éstos sobre los que sólo ulteriores intervenciones arqueológicas o una revisión de los materiales no publicados podrán arrojar más luz.

Al margen del área porticada referida para Tarraca y como edificios propios del equipamiento de los conjuntos forenses apenas contamos con noticias de un arco honorífico — situado en el acceso al cerro de El Pueyo - en el yacimiento de Los Bañales, según noticia que aportara J. B. Labaña ${ }^{139}$ y que llevó a M. Beltrán Lloris a describir dicho monumento, hoy perdido, como un arco de inspiración augústea aunque quizás de cronología algo posterior ${ }^{140}$; o los edificios constructivos de buena factura y refinada decoración aun indeterminados en la plataforma del cerro de Santacrís, quizás atribuibles al espacio forense ${ }^{141}$.

\section{1. 3. Templos}

Como estudiamos con anterioridad ${ }^{142}$ sólo los hallazgos estatuarios o la pervivencia de la huella de antiguos cultos en edificaciones cristianas posteriores nos han permitido suponer la existencia de éstos en Pompelo y en Calagurris, templos para los que, en cualquier caso, no hay aun suficientes bases arqueológicas.

Al margen de estos dudosos casos, como edificio cultual podría interpretarse, por sus capiteles, el magnífico conjunto de Cara ${ }^{143}$ del mismo modo que se han excavado templos en Gracchurris - un sencillo edículo in antis de datación augústea ${ }^{144}$-; Oiasso — de finales del siglo II d. C., y construido sobre una antigua necrópolis en el área de Santa Elena de Irún ${ }^{145}$ aunque hay quien prefiere interpretar dicha construcción como un simple monumento funerario ${ }^{146}$-; y Tarraca — si es que en este enclave sólo hubo uno, en el área del foro ${ }^{147}$, y no habrá que buscar otros bien en El Pueyo o en el entorno de la actual ermita de Nuestra Señora de los Bañales ${ }^{148}$-.

138 Beltrán Lloris, F.: op. Cit. (n. 8), págs. 163-164 (con foto).

139 LABAÑA, J. B.: Itinerario del Reino de Aragón, Madrid [edición Diputación de Zaragoza, Zaragoza, 1895] 1610, pág. 302.

140 Beltrán LloRis, M.: op. Cit. (n. 92), pág. 236.

141 Armendáriz, R., Mateo, M. ${ }^{a}$ R., SÁez de Albéniz, M. a P.: Santa Cruz, una necrópolis..., pág. 828.

142 Véase, al respecto, nota 116 (para los casos de Pompelo y de Calagurris) y nota 114 (para el de Andelo).

143 Sobre ellos, véase nota 116 en este mismo trabajo.

144 NúÑEZ, J.: op. Cit. (n. 12), pág. 134.

145 Rodríguez Salís, J.: «Romanización en el Bidasoa. Datos para su estudio», ED, 20, (1971), págs. 149-153; y, especialmente Barandiarán, I., Martín Bueno, M., y Rodríguez Salís, J.: op. Cit. (n. 85), págs. 269-271. Con argumentos a favor de la interpretación votiva del edificio puede verse FERNÁNDEZ OChOA, C., y Morillo, A.: op. Cit. (n. 8), pág. 149.

146 NúÑEZ, J.: op. Cit. (n. 12), págs. 134-135.

147 Galiay, J.: op. Cit. (n. 63), pág. 82, después mejor descritos en LostaL, J.: Arqueología del Aragón Romano. Zaragoza, 1980, pág. 84.

148 Beltrán LlORIS, F.: op. Cit. (n. 8), págs. 163-164 puso en relación algunos materiales moldurados y basas de columna que halló GALIAY, J.: op. Cit. (n. 65), págs. 22-29 con un edificio noble que se abriría a la antes descrita como plaza Norte de El Pueyo (véase, en este mismo trabajo, nota 135). 


\section{2. Edificios de espectáculos}

Pocas ciudades hispanas como Calagurris - la única del territorio de los Vascones para la que hay noticias fehacientes de edificios de espectáculos ${ }^{149}$ - ofrecen tantos testimonios indirectos sobre la existencia de estos conjuntos tan singulares que se cuentan, además, entre los más espectaculares de la ingeniería y arquitectura romanas. Así, para la época de Tiberio-Claudio consta la habitual celebración de ludii gladiatorii a partir de la figura de un gladiador secutor y la leyenda municipio Calag(orritano) de una cerámica ${ }^{150}$ procedente de la colonia $\mathrm{Cel}$ sa, en Velilla de Ebro (Zaragoza), noticia que tiene su eco en otro fragmento procedente del alfar calagurritano de La Maja con referencia a unos [munera?] gladiato[rum - $j^{151}$. Posiblemente algo más tarde — pues la cronología de estas piezas puede llegar hasta la época Flavia - otros dos fragmentos cerámicos también, como el anterior, procedentes del alfar local de La Maja ${ }^{152}$ - conmemoran la celebración de circienses munic(ipi) Calagorri lul(iae) pri(die) idus Decembres, el primero, $\mathrm{y}$-a juzgar por los motivos iconográficos - la de otro festejo semejante, el segundo, prima IIII k(alendas) Septembres ${ }^{153}$. En época tardoantigua, también Prudencio ${ }^{154}$ alude a los espectáculos públicos celebrados en la ciudad.

Sin embargo, la generosidad de las fuentes literarias y -especialmenteepigráficas no está en consonancia con la entidad de los restos arqueológicos conocidos ni para el anfiteatro ni para el circo de Calagurris. Del primero - para el que U. Espinosa rastreó noticias en la documentación del siglo $\mathrm{XIX}^{155}$ - sólo

149 Hay que pensar - al margen de las sorpresas que pueda depararnos la investigación arqueológica en años venideros - en el poder de atracción que desempeñarían los edificios de espectáculos -y en especial el teatro- de la colonia Caesaraugusta, capital del conuentus iuridicus en que tributaban los Vascones, como ha planteado BELTRÁN LLORIS, M.: «El teatro de Caesaraugusta. Estado actual de conocimiento", en Teatros romanos de Hispania. Murcia, 1993, págs. 93-118. Por su parte —también desde un punto de vista acertado- NúÑEZ, J.: op. Cit. (n. 12), pág. 135 ha contextualizado la escasez de testimonios con lo que sucede en las regiones próximas al Pirineo, estudiadas por DuMASSY, F., y FINCKER, M.: «Les édifices de spectacle», en Villes et aglomérations urbaines antiques du Sud-Ouest de la GauIle. Histoire et Archeologie. Burdeos, 1990 págs. 203-225.

150 BELTRÁN LLORIS, M.: «Ludus Calagurritanus: relaciones entre el municipium Calagurris lulia y la coIonia Victrix Iulia Celsa», en Calahorra. Bimilenario de su fundación. Calahorra, 1984, págs. 129-138, esp. Pág. 130 (para el comentario del titulus cerámico) y pág. 132 (para la cronología estratigráfica del hallazgo cerámico).

151 Ceballos, A.: Los espectáculos en la Hispania Romana. La documentación epigráfica. Mérida, 2004, n. $^{\circ} 10$.

152 GonzÁlez Blanco, A.: «El alfar romano de La Maja (Pradejón, Calahorra). Historia de la investigación», Kalakorikos, 2, (1997), págs. 9-21.

153 Para este último, véase González Blanco, A., JimÉneZ, F. J., y CinCA, J. L.: «Un nuevo testimonio de juegos circenses, también del ceramista Gaius Valerius Verdullus» en BELTRÁn LloRIS, F. (ed.): op. Cit. (n. 55), págs. 251-254 (AE, 1995, 889b) y para el anterior, nota 111 en este mismo trabajo. También guarda relación con ludi circienses el titulus HEp9, 488 (IIluir circ[--] según CeBALlos, A.: op. Cit. (n. 147), n. 8bis).

154 PRUD., Perist. I, vv. 215-218. Sobre dichas menciones, véase: MARTín, M.: «Los espectáculos públicos en la Calahorra de Prudencio», en Calahorra. Bimilenario de su fundación. Calahorra, 1984, págs. 225-230.

155 Espinosa, U.: op. Cit. (n. 8), pág. 117. 
A. González Blanco ha querido ver huellas de su construcción en la C/San Antón y en el área de bodegas del entorno de la Casa Santa, en las que existen indicios de estructuras arquitectónicas de considerable volumen y de factura romana ${ }^{156}$. Por su parte, al margen de la amplísima bibliografía ${ }^{157}$ que ha generado, poco se sabe del circo del municipio calagurritano al margen de su fosilización urbanística en el espacio actual de El Mercadal ${ }^{158}$ - lo que le conferiría, ciertamente, una longitud de casi 230 metros en el eje longitudinal y 60 en el transversal-y de lo infundado -al menos con los datos arqueológicos con que se cuenta hasta la fecha- de su utilización para naumachiae ${ }^{159}$.

\section{3. Obras hidráulicas}

Suficientemente bien conocidos son los monumentales y completos conjuntos hidráulicos que se encargaron del abastecimiento de agua a Calagurris y a Ande$10^{160}$ así como el acueducto que llevó el agua a la ciudad de Tarraca ${ }^{161}$ y que, como ha remarcado J. Núñez, constituye el único ejemplo conocido hasta la fecha con un specus que debió estar íntegramente construido en madera ${ }^{162}$. Sobre éste último

156 González Blanco, A.: «El anfiteatro de Calahorra», Kalakorikos, 3, (1998), págs. 193-196.

157 MoRET, J. de: op. Cit. (n. 15), págs. 42-43; CEÁN, J. A.: Sumario de las antigüedades romanas que hay en España, en especial las pertenecientes a las Bellas Artes. Madrid, 1832, pág. 138; MÉLIDA, J. R.: Monumentos romanos de España. Madrid, 1925, pág. 86; TARACENA, B.: «Restos romanos en La Rioja», $A E A, 15$, (1942), págs. 17-47, esp. Págs. 28-29 donde se pronuncia en un aforo de casi 30.000 espectadores, asunto sobre el que luego vuelve en «Arte Romano», Ars Hispaniae. II. Madrid, 1947, págs. 9179, esp. Pág. 72; Pericot, L.: Historia de España. I. Barcelona, 1958, pág. 404; GARcía y BeLlido, A.: «Parerga de arqueología y epigrafía hispano-romanas», $A E A, 33$, (1960), págs. 167-193, esp. Pág. 192; GutiéRREZ, P.: Calahorra vencedora e invencible. Calahorra, 1966, pág. 44; y EsPINosA, U.: op. Cit. (n. 8), págs. 78-83. A día de hoy, la mejor descripción sigue siendo la de CEÁN, J. A.: Sumario de las antigüedades..., pág. 138: «(...) por donde se sale de Calahorra para ir á Logroño, están las ruinas de un Circo Máximo: son de ladrillo y argamasa: tienen de largo 489 pasos comunes, 116 de ancho, y las paredes 22 pies de grueso, y se señalan las gradas en que se sentaban los espectadores», tomando de MORET, J. de: op. Cit. (n. 15), págs. $42-43$ la interpretación sobre la celebración de naumachiae en su interior.

158 Espinosa, U.: op. Cit. (n. 8), pág. 78.

159 Martín Bueno, M., y Cancela, M. ${ }^{a}$ L.: op. Cit. (n. 116), pág. 88.

160 El repertorio de las conducciones de agua (presa de Mendavia-acueducto Alcanadre/Lodosa; acueducto en Sorbán-La Planilla; y en La Degollada, complementado con un extraordinario sistema de saneamiento urbano excavado, por ejemplo, en un tramo en la C/San Andrés: CINCA, J. L.: «Las cloacas romanas de Calahorra», en XVII Congreso Nacional de Arqueología (Logroño, 1983). Zaragoza, 1985, págs. 797-807 y «Un nuevo tramo de cloaca romana descubierto en Calahorra (La Rioja)», en Miscelánea. Arqueología de Calahorra. Calahorra, 1991, págs. 139-157) que proveían a Calagurris puede seguirse, de forma crítica, en EspinosA, U.: op. Cit. (n. 8), págs. 113-115, una de las cuales —la de Lodosa- es descrita pormenorizadamente en MEZquíRIZ, M. a A.: «El acueducto de Alcanadre-Lodosa», TAN, 1, (1979), págs. 139-149, esp. Pág. 143 (para la caput aquae) y Págs. 139-143 (para la técnica constructiva de las arcuationes y el specus) y, como obra de conjunto PASCUAL, P.: «Abastecimiento de agua a Calagurris», en Miscelánea. Arqueología de Calahorra. Calahorra, 1991, págs. 55-104. El caso ejemplar andelonense en MezQuíRIz, M. a A., y UnzU, M.: op. Cit. (n. 127), págs. 238-241 (para la presa), págs. 244-247 (para el depósito), págs. 247-258 (para la conducción de agua a la ciudad), y págs. 258265 (para el castellum aquae o diuisorium del núcleo urbano).

161 El acueducto de Los Bañales fue estudiado por Beltrán MARTínez, A.: op. Cit. (n. 135), págs. 91129, esp. Págs. 94-102.

162 NúÑ̃Z, J.: op. Cit. (n. 114), pág. 124. 
queda aun por localizar su caput aquae y por insertar con exactitud en el complejo hidráulico los dos posibles castella aquae que - a modo de grandes balsashan dejado su impronta en el paisaje de Los Bañales al Este del espacio antes descrito como plaza porticada y en la ladera Sur de El Pueyo - este último, seguramente vinculado a la termas-. Más allá de los rasgos arqueológicos de tan soberbios conjuntos, nos interesa resaltar aquí que los tres parece fueron construidos en el lapso entre finales del siglo I y comienzos del siglo II d. C. entrando seguramente en desuso hacia el siglo III d. C., como se ha documentado para el caso de Andelo y como puede inferirse de la fecha de abandono de las termas a las que servía agua para el caso de Tarraca ${ }^{163}$. Precisamente, es a partir de esa época cuando, y seguramente al servicio de las uillae agrícolas del entorno, hay que fechar los conjuntos de presa y fuente de El Sotillo y El Burgo en el territorium de Gracchurris $^{164}$ y quizás el ya perdido dique de las cercanías de Los Bañales ${ }^{165}$ y otro del entorno de Cascantum del que da noticia reciente F. Beltrán Lloris a propósito del riuus Hiberiensis ${ }^{166}$.

Establecimientos termales canónicos se han estudiado en Tarraca, Calagurris, Andelo y Pompelo ${ }^{167}$, contándose con evidencias de conjuntos en Gracchurris y Oiasso, quizás menores por no haber sido excavados en su totalidad en el primer caso o por sus dimensiones, en el segundo ${ }^{168}$. Estudios ulteriores deberán profundizar en la red de saneamiento urbano que ha sido documentada en Calagurris y en Pompelo ${ }^{169}$.

163 Beltrán Martínez, A.: op. Cit. (n. 135), pág. 129 —para la cronología del de Tarraca- y MezQuíRIZ, M. ${ }^{a}$ A., y UnZU, M.: op. Cit. (n. 127), pág. 266 —para la del de Andelo-.

164 V. V. A. A.: Graccurris. Conjuntos monumentales en la periferia urbana: puentes, presas, ninfeos [n. ${ }^{\circ} 4$ de Graccurris]. Logroño, 1995.

165 Martín Bueno, M.: «Dique romano en Cinco Villas», Miscelánea Arqueológica al Profesor Antonio Beltrán. Zaragoza, 1975, págs. 251-257, esp. Pág. 257, para la cronología, a partir del tipo de aparejo.

166 BeLtRÁN LlORIS, F.: Irrigación y organización..., pág. 234, nota 14.

167 Las termas de Los Bañales fueron estudiadas, junto al acueducto, por BeLtRÁn MARTínEZ, A.: op. Cit. (n. 135), págs. 102-118 y, de forma monográfica en Las termas..., págs. 192-193 y en «El tubo de plomo del frigidarium de las termas de Los Bañales (Uncastillo, Zaragoza)», en XIV Congreso Nacional de Arqueología (Vitoria, 1975). Zaragoza, 1977, págs. 1049-1054, esp. Pág. 1050. Las de Andelo por MezquíRIz, M. a A.: La ciudad de Andelos..., pág. 311. Para Calagurris disponemos de noticias actualizadas a partir de LUEZA, R. A.: «Termas romanas en el municipium Calagurris lulia (Calahorra, La Rioja)", en Fernández OchoA, C., y García, V. (eds.): Termas Romanas en el Occidente del Imperio. Gijón, 2000, págs. 185-192, esp. Págs. 185-189 para las públicas de la Pila de los Moros, la fábrica Torres, las C/Eras y San Blas y la Crtra. de Arrendó. Las de Pompelo en Unzu, M., Prieto, P., Peréx, M. a J., y Hernando, A.: op. Cit. (n. 89).

${ }_{168}$ La existencia de termas en Gracchurris sólo puede inferirse de la interpretación dada a un monumental conjunto de muros de opus caementicium y argamasa hidráulica por NúÑ̃E, J.: op. Cit. (n. 12), pág. 139 y que, por el hallazgo en sus niveles fundacionales de fragmentos de sigillata itálica puede fecharse en los inicios de la época imperial. El caso de Oiasso (Gereñu, M., LóPez, M. ${ }^{a}$ M., Urteaga, M. ${ }^{a}$ M.: op. Cit. (n. 99), pág. 476) ha sido interpretado por sus excavadores como un pequeño conjunto termal con interesantes paralelos en las termas conocidas para la mansio de Imus Pyrenaeus en Saint Jean le Vieux.

169 EspinosA, U.: op. Cit. (n. 8), págs. 113-114 y MezQuíriz, M. ${ }^{a}$ A.: «Segunda campaña de excavaciones en el área urbana de Pompelo», PV, 100-101, (1965), págs. 375-380, respectivamente. 


\section{4. Arquitectura doméstica}

A partir del catálogo de viviendas excavadas en las ciuitates de los Vascones se puede trazar una cierta panorámica diacrónica de la evolución del patrón de vivienda hispanorromano. Así, las viviendas de cronología republicana excavadas en Cascantum, Gracchurris, Andelo y Pompelo ${ }^{170}$ ponen de manifiesto los rasgos típicos de la vivienda romana de la época ${ }^{171}$ y la rápida recepción de elementos suntuarios romanos - mosaicos de opus signinum, grandes sillares, amplias estancias, sistemas de aislamiento de la humedad, etcétera...- de una elite que no renuncia, sin embargo, a hacer gala de sus tradiciones locales como demostraría el célebre mosaico de Andelo, al que ya nos referimos. Con inicio bien en época augústea - caso de Gracchurris ${ }^{172}$ — bien, especialmente, en época Flavia —casos de Calagurris, Andelo, Ilumberi y probablemente Pompelo ${ }^{173}$ - las viviendas empiezan a incorporar zócalos con crustae marmóreas, estucos decorativos en las paredes y mosaicos de opus tessellatum con motivos figurados. Quizás el ejemplo de la domus excavada en «La Clínica» de Calahorra constituya el mejor ejemplo del ambiente general de prosperidad que se percibe en la mayor parte de ciuitates de los Vascones - en lo que al horizonte de la arquitectura doméstica se refiere-entre los últimos decenios del siglo i y finales del siglo ı/comienzos del III d. C. en que se abandonan algunas de estas viviendas en beneficio, como vimos, de los establecimientos fundiarios del territorium municipal circundante.

170 Para el caso de Cascantum, véase una descripción en MezQuíRIz, M. ${ }^{a}$ A.: Recientes hallazgos..., págs. 267-280; para el de Gracchurris: MARTínEZ, J. M.: «Alfaro. Excavaciones Arqueológicas en las Eras de la Cárcel. Campaña de 1996», Estrato, 8, (1997), págs. 58-64; para el caso de Andelo especialmente VELAZA, J.: op. Cit. (n. 69), págs. 626-630 —con atención a su inserción en la evolución urbanística de la ciudad-y Mezquíriz, M. ${ }^{a}$ A.: Andelos: secuencia estratigráfica..., pág. 518; y para el de Pompelo: MezquíRIz, M. ${ }^{\text {a }}$ A.: Vestigios romanos..., pág. 127. Condicionado por los datos de las excavaciones de los años cuarenta, sigue sin cerrarse la cronología —al menos en los niveles de arranque del poblamiento- de las viviendas del cerro de El Pueyo de Los Bañales, que BALIL, A.: Casa y urbanismo en la España Antigua. I, Valladolid, 1971, pág, 31 consideraba de tradición ibérica, y que, sin embargo tenían una filiación romana para BELTRÁN LLORIS, F.: Sobre las últimas excavaciones..., pág. 1059. MARTíN BuEno, M.: op. Cit. (n. 61), pág. 113 ha querido ver en este rápida introducción de los gustos romanos un procedimiento de Roma para facilitar la integración de los indígenas, estudiándolo especialmente para el caso de Gracchurris, para la que, a su juicio, llama la atención la rápida presencia de productos de importación y de cerámicas refinadas.

171 BaLIL, A.: op. Cit. (n. 170), y Casa y urbanismo en la España Antigua. II. Valladolid, 1972, y, con algunos de los más conocidos modelos V. V. A. A.: La Casa urbana hispanorromana (Zaragoza, 1988), Zaragoza, 1991 y Merse, W. E.: op. Cit. (n. 81), págs. 49-91.

172 Hernández Vera, J. A.: op. Cit. (n. 8), pág. 181, época en la que se construye una gran domus peristilada y que, parece ser coincide con el floruit de la ciudad, según HERNÁNDEZ VERA, J. A., y CASADO, P.: op. Cit. (n. 71), pág. 24.

173 Sobre la domus de «La Clínica» de Calagurris, véase ESPINOSA, U.: op. Cit. (n. 8), págs. 134-137. Sobre la denominada "Casa del Peristilo» de Andelo puede verse MEZQuíRIZ, M. a A.: Actividad arqueológica..., pág. 331. Para el caso de Pompelo: MezQuíRIz, M. a A.: Algunas aportaciones..., págs. 192-193. Para el de llumberi, con mosaicos del siglo II d. C., ya aportamos con anterioridad la bibliografía (véase nota 26). 


\section{5. Necrópolis}

Pese a la notable documentación epigráfica funeraria de que se dispone para el solar vascón ${ }^{174}$, tal como afirmaron M. Unzu y M. ${ }^{2}$ J. Peréx ${ }^{175}$, la casi absoluta totalidad de los epígrafes conocidos proceden de hallazgos sueltos o descontextualizados mientras que las necrópolis excavadas no han aportado material epigráfico alguno. Así, en yacimientos adscribibles a un horizonte urbano se han realizado excavaciones en las necrópolis de Iturissa, Santacrís y Oiasso ${ }^{176}$. Sin embargo, por noticias diversas - fundamentalmente epigráficas pero también derivadas de intervenciones arqueológicas mal documentadas o de urgencia- se conocen los emplazamientos de las de Calagurris, Tarraca, y Andelo ${ }^{177}$.

Para los objetivos del presente trabajo interesa destacar cómo -aunando ahora la documentación arqueológica y la epigráfica- puede seguirse una cierta evolución de la cultura epigráfica -incluso en áreas rurales- hacia tipos más netamente romanos bien concretados en grandes conjuntos arquitectónicos como los denominados «Mausoleos» de Santacrís, el Mausoleo de los Atilios de Sádaba —vinculado a la ciuitas de Tarraca-, el que debió albergar el conjunto epigráfico de la ermita de Nuestra Señora de Andión, la torre funeraria del núcleo indeterminado de Sofuentes ${ }^{178}$, o el pequeño ustrinum de Oiasso - todos ellos fechables en la segunda mitad del siglo । y los comienzos del II d. $\mathrm{C}^{179}$ - bien en la adopción de modas funerarias -éstas extendidas más a partir de la época antoniniana - como la de las cupae o la del retrato funerario que - hasta donde al-

174 Tomando como base el repertorio que ofrecemos en el Mapa: «Epigrafía Latina en el solar de los Vascones", compuesto por un total de 203 inscripciones, son funerarias 119 frente a sólo 24 votivas y 60 que se reparten entre miliarios, monumentales, e indeterminadas/otras, con notable presencia de miliarios (29), aunque muy concentrados en el sector de la Navarra Media Occidental-Cinco Villas de Aragón. Con estas cifras, la epigrafía funeraria constituye, por tanto, hasta un 58,6\% de la documentación epigráfica del solar de los Vascones.

${ }_{175}$ UnzU, M., y PERÉX, M. a J.: «La cultura funeraria en Navarra en época romana», Isturitz, 9, (1997), págs. 797-815, esp. Pág. 798.

176 Al margen de la valoración que de los tres conjuntos hacen UnZU, M., y Peréx, M. ${ }^{a}$ J.: op. Cit. (n. 175), págs. 809-814, las respectivas excavaciones pueden seguirse en: PERÉX, M. ${ }^{a}$ J., y UNZU, M.: «Resumen de las campañas de 1989-1990. Una nueva necrópolis de incineración en el término de Espinal», TAN, 10, (1991-92), págs. 446-447 (para la de Otegui, en Iturissa) y «Necrópolis y poblado de época romana en Espinal (Navarra)», TAN, 13, (1997-98), págs. 75-155, esp. Págs. 80-81 (para la de Ateabalsa, en Iturissa); en ArmendáRIZ, R., Mateo, M. ${ }^{a}$ R., SÁEZ de Albéniz, M. ${ }^{\text {a }}$ P.: Santa Criz, una necrópolis..., págs. 831-835 (para la de Santacrís); y BARANDiARÁn, I., MARTín Bueno, M., y RodríGuez Salís, J.: op. Cit. (n. 87) (para la de Oiasso).

177 Espinosa, U.: op. Cit. (n. 8), págs. 119-120 ubica las necrópolis calagurritanas una al final del Paseo del Mercadal (donde fueron halladas en el siglo pasado las inscripciones funerarias CIL, II, 2984, de Iulius Longinus y CIL, II, 2983, de C(aius) Varius Domitia[nus]), otra en el área del Instituto Nacional de Previsión, a partir de unos hallazgos inventariados por GUTIÉRREZ, P.: Calagurris Julia..., pág. 206 y otra en el área del Instituto de Enseñanza Media, justo al pie de la uia que accedía a la ciudad. La de Tarraca fue ubicada por GaliaY, J.: Las excavaciones del Plan..., pág. 21 en uno de los cerros al Sur de la zona monumental de Los Bañales, de donde proceden CIL, II, 2977-79, asunto sobre el que volvió LosTAL, J.: op. Cit. (n. 145), págs. 89-90. De la de Andelo sólo tendríamos constancia en el repertorio epigráfico embutido en la ermita de Nuestra Señora de Andión (CIL, II, 2966 y 2967) ya referido.

178 Véase, con la oportuna bibliografía, notas 84-85.

179 Fernández OchoA, C., y Morillo, A.: op. Cit. (n. 8), pág. 149. 
canza nuestra documentación- parece debió tener cierto éxito en el límite nororiental del territorio vascón ${ }^{180}$ a juzgar por una pieza procedente de Tarraca y otra de Sofuentes ${ }^{181}$.

Ambos grupos de testimonios, y especialmente los primeros, nos ponen en contacto, además, con algunas unidades familiares - los Atilii del entorno de Tarraca, los Aemilii del de Andelo y los Valerii y Cornelii del área de Eslava ${ }^{182}$ - que constituyen ya una activa elite - seguramente económica y, sin duda, también política- que - perfectamente constituida para dicha época - busca dejar constancia de su poder en las áreas de influencia de unas ciuitates que acometen en esta época, además, sus grandes programas edilicios y monumentales en los que, quizás - aunque no nos haya quedado constancia documental- ellos mismos tuvieran algo que ver, como apuntamos con anterioridad.

4.

Cuando, en el proceso de conquista, Roma entra en contacto con las tierras de la actual provincia de Navarra, el sector occidental de la de Zaragoza - hasta el Gállego-y una estrecha banda —la más septentrional, junto al río Ebro- de la actual comunidad de La Rioja lo hace de forma escalonada. En un primer momento - que podría adscribirse cronológicamente a un periodo comprendido grosso modo entre los años 195 a. C. y 184 a. C.- M. Porcio Catón, L. Manlio Acidino y A. Terencio se enfrentan sucesivamente a comunidades que debían constituir ya verdaderas ciuitates: bien organizadas, estratégicamente ubicadas y que, seguramente, ejercían cierta capitalidad sobre los territorios circundantes. Es el caso de lacca - asediada por Catón non Romanos modo cohortes sed iuuentutem infensorum sociorum ${ }^{183}$-, de Calagurris ${ }^{184}$, y de Corbio $^{185}$. Quizás en este momento -o más tarde, en época del conflicto sertoriano- pudo Roma establecer un foedus con Tarraca, que en época de Augusto debía figurar en las fuentes plinianas - y después en el Naturalista- como la única ciuitas foederata del conuentus Caesaraugustanus ${ }^{186}$.

180 Sobre este hecho, véase BELTRÁN LLORIS, M.: «La arqueología de las Cinco Villas (síntesis)», en Actas de las I Jornadas de Estudios sobre las Cinco Villas. Ejea de los Caballeros, 1986, págs. 19-52 y Roma: República..., págs. 253-255 así como, en el contexto del Ebro Medio, Beltrán LlORIS, F., MARTíN Bueno, M., y PINA, F.: op. Cit. (n. 82), págs. 92-151.

181 HAE, 2188=ERZ, 51 (para la procedente del conjunto de Los Bañales de Uncastillo) y AE, 1977, 483 (para la de Sofuentes).

182 Los Atilii de Tarraca están documentados en CIL, II, 2973 (del Mausoleo del mismo nombre, en Sádaba), CIL, II, 2974 (del de otro Atilius en Sofuentes) e HEp6, 999 (de Malpica de Arba, entre las actuales localidades de Sádaba y Ejea); los Aemilii de Andelo en el conjunto epigráfico de CIL, II, 2966, 2967 e HEp3, 263; y los Valerii y Cornelii de Eslava en HEp3, 253; HEp8, 373; IRMN, 40; y HEp9, 432. Estos últimos ya fueron estudiados por CASTILLO, C.: op. Cit. (n. 98), pág. 131. Sobre los dos anteriores, reflexionamos con anterioridad en ANDREU, J.: op. Cit. (n. 6), pág. 202, nota 125.

183 LIV., 34, 20.

184 LIV., 39, 21, 8-9.

185 LIV., 39, 42.

${ }^{186}$ A favor de esta posibilidad se pronuncia recientemente - sin cerrar la opción de que dicho foedus fuera obra de Pompeyo-SAYAS, J. J.: El municipio de Vasconia..., (en prensa), s. págs., al considerar- 
Para esta época del siglo II a. C. la documentación arqueológica procedente de alguna de estas ciudades -lacca y Calagurris pues la reducción de Corbio permanece ignota-corrobora el tipo de poblamiento que caracterizaba a los poblados indígenas del solar que nos ocupa hasta la llegada de Roma. Así, a partir de los datos procedentes de intensivas prospecciones y de contadas intervenciones arqueológicas ${ }^{187}, \mathrm{~A}$. Castiella ${ }^{188}$ ha definido dichos centros como asentamientos de tamaño medio, que ocupaban lugares prominentes y con capacidad para controlar tierras fértiles, vías de comunicación y cursos de agua y, generalmente, amurallados, aspecto éste que las excavaciones desarrolladas en lacca han demostrado. Así, se ha contactado con un lienzo de muralla, una puerta de acceso y abundante material cerámico indígena que, seguidamente, convive con las formas cerámicas romanas más usuales de la Campaniense $\mathrm{A}$ y que $\mathrm{J}$. $\mathrm{Paz}{ }^{189}$ ha fechado en la segunda mitad del siglo II a. C., por tanto en el momento en que esta porción del futuro solar vascón se ve salpicada por los conflictos militares a que nos venimos refiriendo. Por su parte, y pese a la escasez de datos arqueológicos con que se cuenta para la Calagurris indígena de la época -excepción hecha de un pequeño lote cerámico de tradición ibérica procedente del área de la muralla y del solar de «La Clínica» ${ }^{190}$ — parece demostrado que ésta —aprovechando su prominente situación estratégica a orillas del Cidacos y no demasiado lejos de la confluencia de éste con el Ebro'191 - debía constituir el centro de una serie de pequeños poblados de la II Edad del Hierro ubicados en su entorno ${ }^{192}$.

\footnotetext{
la un reflejo de la estructura ya urbana -y política- de que debían disfrutar algunas ciuitates de los Vascones para el siglo II a. C. siendo - a su juicio- buena prueba de ello la actividad acuñadora de las cecas monetales prelatinas cuyo solar está aun por localizar. Una fecha temprana para este foedus - que parece encajar mejor con la temprana actividad militar registrada en este sector oriental del futuro solar vascón, como hemos apuntado en ANDREU, J.: op. Cit. (n. 6), pág. 201, nota 118- explicaría que, además, por medio de éste, y como apuntara BLÁZQUEZ, J. M. a .: «Los vascos y sus vecinos en las fuentes literarias griegas y romanas de la Antigüedad», en IV Symposium de Prehistoria Peninsular. Pamplona, 1966, págs. 177-202, esp. Pág. 198, Roma protegiera a los Vascones contra el expansionismo de los Celtiberi de la margen derecha del Ebro. En el estado actual de nuestros conocimientos, el aporte de grano - y más si se acepta la reducción Tarraca=Los Bañales de Uncastillo, en el centro de un valle que, todavía hoy, se cuenta entre los más fértiles del secano aragonés- parece la contrapartida lógica aportada por los indígenas en el citado convenio, como indicara PERÉX, M. a J.: Tarraca, ciudad federada..., pág. 488. Al respecto de esta dedicación eminentemente agrícola del enclave de Tarraca habría que mencionar los interesantes indicios de un parcelado romano que fueran estudiados por LABE, L. F.: op. cit. (n. 18), pág. 831 en el área entre Los Bañales, Sádaba y Biota. Sobre la posibilidad de enmarcar este foedus algo más tarde, en el contexto de la actividad de Ti. Sempronio Graco puede verse SAYAS, J. J.: La comarca de Tudela..., pág. 155 y sobre una posible fecha sertoriana, aun más reciente: AmELA, L.: «Navarra, Roma e Hispania: Pompeyo», en Andreu, J. (ed.): op. Cit. (n. 2), págs. 137-166, esp. Pág. 164.

187 Concretamente en EscALADA, F.: La arqueología en la villa y castillo de Javier y sus contornos. Pamplona, 1943; TARACENA, B., y VÁzQUeZ DE PARGA, L.: «Exploración en el poblado celtibérico de Fitero», PV, 22, (1946), págs. 225-242; MALUQUER, J.: «Notas estratigráficas del poblado celtibérico de Fitero (Navarra)», PV, 100-101, (1956), págs. 331-342; CASTIELLA, A.: «Nuevos yacimientos protohistóricos en Navarra», TAN, 5, (1986), págs. 133-176; y ARMENDÁRIZ, R. M.a., MATEO, M. ${ }^{a}$ R., y NuIN, J.: «Intervención arqueológica en Sancho Abarca (Fitero), 2001», TAN, 16, (2002-2003), págs. 79-106

188 Castiella, A.: op. Cit. (n. 120), pág. 179.

189 Paz, J.: op. Cit. (n. 8), pág. 334 y OnA, J. L., PAZ, J., PÉreZ, J. A., y De Sus, M. ${ }^{a}$ L.: op. Cit. (n. 8), p. 11.

190 Espinosa, U:: op. Cit. (n. 8), págs. 111-127.

191 Gómez-Pantoja, J.: op. Cit. (n. 78), pág. 185.

192 Castiella, A.: La Edad del Hierro..., págs. 152-154.
} 
Tras la toma de Corbio las noticias con que - para el solar de los Vasconesnos obsequian las fuentes literarias se interrumpen durante casi diez años de suerte que éstas sólo vuelven a referirse al territorio que nos ocupa a propósito de la fundación de Gracchurris por Ti. Sempronio Graco tras la victoria de éste sobre los Celtíberos en el mons Chaunus ${ }^{193}$. Posiblemente repoblada con Vascones ${ }^{194}$, la conversión de la celtíbera Ilurcis en la romana Gracchurris ${ }^{195}$ —que, además, toma el nombre de su deductor-supone un primer hito en la integración de estas tierras - al menos las del entorno del Ebro- en el modelo de la ciuitas. Tal como documenta el citado pasaje de Festo y después ha refrendado la documentación arqueológica, la Gracchurris romana se asienta directamente sobre el solar que antes había ocupado la llurcis celtibérica de tal modo que apenas se percibe discontinuidad entre la primera fase de la ciudad —adscribible a la Edad del Hierroy la segunda ${ }^{196}$ - con notable presencia de materiales romanos-. La razón es lógica y debe buscarse, a nuestro juicio, en las excelentes condiciones estratégicas que constituyen las principales fortalezas del alto de las Eras de la Cárcel de la localidad riojana de Alfaro: un cerro defendido de forma natural por tres de sus lados y abierto al río Alhama, no lejos del Ebro, y en el cruce de las vías naturales que constituyen los ríos Aragón y el propio Alhama.

Nos hemos detenido en la situación de Gracchurris que - como hace tiempo señalara N. Dupré ${ }^{197}$ - constituye un claro ejemplo de emplazamiento con vocación de control porque parece plausible pensar que en el segundo momento cronológico de la integración de estas tierras en la órbita de Roma -entre el 179 a. C., precisamente, y la década de los 80 a. C. con la concesión uirtitutis causa de la ciuitas Romana a los jinetes de la turma Salluitana, entre ellos siete Segienses, por parte de Cn. Pompeyo Estrabón y la mención a la ciuitas de los Alauonenses en la venta de unos terrenos a Salduie por la ciuitas Sosinestana que documenta la tabula Contrebiensis ${ }^{198}$ - fue cuando debieron desaparecer muchas comunidades indígenas, surgiendo otras - que generalmente eran fruto de la validación por parte de Roma de antiguas jerarquías territoriales locales- bien a través de procesos -espontáneos o dirigidos- de sinecismo (caso de Calagurris, como apuntamos anteriormente) bien por medio de traslados in planum como parece plausible suponer para el caso de Cascantum $^{199}$. Así, en esa época intermedia ya florecían como ciuitates la mayor parte de las presentes en la línea del Ebro: Calagurris -que acuñó moneda con leyenda kalakorikoś en esta primera mitad del siglo I

193 LIV., Per., 41.

194 LÓPEZ MELERO, R.: «¿Gracchurris, fundación celtibérica?», Veleia, 4, (1987), págs. 171-177 y también, con otra perspectiva WIEGELS, R.: «lliturgi und der 'deductor` Ti. Sempronius Gracchus», MM, 23, (1982), págs. 169-173.

195 FEST., 862.

196 Hernández Vera, J. A., y Casado, P.: op. Cit. (n. 71), pág. 24.

197 Dupré, N.: op. Cit. (n. 71), pág. 150.

198 Para el bronce de Áscoli: ClL, I², 709 y, para la tabula Contrebiensis véase, en este mismo trabajo, nota 22.

199 ArmendáRIz, J.: op. Cit. (n. 23), págs. 621-625. 
a. C. ${ }^{200}$ - Gracchurris - fundada, como hemos visto, en el 179 a. C.-, Cascantum - para la que J. Pascual ha propuesto también una función de control de la frontera vascona con la tribu celtibérica de los lusones, a la que ésta había debido pertenecer previamente ${ }^{201}$ - y Alaun - que también acuñaría numerario prelatino desde finales del II a. $\mathrm{C}^{202}$., y que disfrutaba ya de cierta personalidad jurídica, reconocida por Roma, como documenta la tabula Contrebiensis-. El posterior avance de Sertorio - en el 76 a. C.- in fines Cascantinorum et Graccuritanorum es sólo una prueba más del modo como estas comunidades -y la propia Calagurris, a la que se dirigía - habían ya implantado el modelo de la ciuitas ${ }^{203}$.

La arqueología no hace sino sancionar esa rápida integración que más arriba hemos descrito a partir de la adopción de sistemas ornamentales como el opus signinum, las decoraciones marmóreas de los zócalos de las paredes, o la vajilla romana que, por ejemplo, tenemos documentado -en el caso de los elementos arquitectónicos - para la vivienda excavada a los pies del cerro de Nuestra Señora del Romero, en Cascante, y que se ha venido fechando en torno al 70 a. $\mathrm{C}^{204}$ y -además de en lo arquitectónico, también en el material mueble- para algunos sectores del yacimiento de las Eras de la Cárcel, en Alfaro ${ }^{205}$. Que en todos los casos anteriormente citados Roma respetara —con probables aportes poblacionales de núcleos vecinos menores- su original ubicación vuelve a poner de manifiesto la importancia que - todavía en esta época - tenía la elección de una buena posición estratégica - pero también económica - para la erección de una ciuitas, criterios que todavía estarán vigentes, por ejemplo, en el De architectura de Vitrubio ${ }^{206}$. Más allá del Ebro, hacia el Este, aprovechándose también de sus excelentes condiciones estratégicas sobre el río Aragón y los pasos pirenaicos, en el primer

200 Sobre los testimonios de estas acuñaciones y la posible fecha de las mismas, con la bibliografía

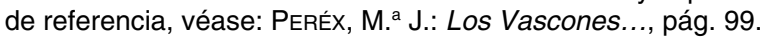

201 PAsCuAL, J.: «El municipium Cascantum y los progresos de la romanización en el sur de la actual provincia de Navarra», en I Congreso General de Historia de Navarra. 2. Comunicaciones. Pamplona, 1987, págs. 547-557, esp. Pág. 549.

202 Beltrán Martínez, A.: Curso de Numismática..., págs. 325-328.

203 LIV., Per., 91 y, al respecto, SAYAS, J. J.: Protohistoria e historia..., pág. 98. La incidencia de las devastaciones sertorianas que sí se ha documentado en otras zonas del valle del Ebro (BELTRÁN LLORIS, M.: «Introducción a las bases arqueológicas del valle medio del río Ebro en relación a la etapa prerromana», en Estudios en Homensaje al Profesor Antonio Beltrán Martínez. Zaragoza, 1986, págs. 495528 y «Problemas arqueológicos de la Celtiberia aragonesa», en I Symposium sobre Celtíberos. Zaragoza, 1987, págs. 19-42) resulta aun poco conocida para la Ribera de Navarra y los poblados próximos al Ebro riojano y que se integrarían en el antiguo solar de los Vascones. El tema -aunque ante sus conclusiones ha de extremarse la prudencia, por proceder, muchas veces, de prospecciones en superficie- ha sido estudiado recientemente por ARMENDÁRIZ, J.: op. Cit. (n. 23), págs. 630-638 que ha documentado indicios de devastación de poblados en esta época en San Sebastián de Cintruénigo; La Custodia de Viana -éste, adscrito, lógicamente, a territorio berón-; o, más al Norte, El Castillo de Irulegui. Algunas interesantes novedades ha aportado, al respecto, el reciente trabajo de OLCOz, S., y MEDRANO, M.: «Tito Livio: Castra Aelia y el límite meridional del ager Vasconum, antes y después de Sertorio", en VI Congreso General de Historia de Navarra. Navarra: Memoria e Imagen. Pamplona, 2006, págs. 55-77.

204 MezQuíRIz, M. a A.: Descubrimiento de pavimentos..., págs. 279 y 292.

205 Martín Bueno, M.: op. Cit. (n. 61), pág. 113.

206 VITRUB., De arch., I, 4. 
caso, y sobre los ríos Arba en el segundo ${ }^{207}$, las ciuitates de Segia y de lacca acuñaban también moneda aunque los restos arqueológicos datables en esta época no se hayan documentado todavía.

Entretanto, y a partir de un conocido - y discutidísimo ${ }^{208}$ - texto de Salustio, sabemos que en torno al 75-74 a. C., Pompeyo instaló presumiblemente sus castra statiua entre los Vascones fundando Pompelo - según indiscutible noticia de Estrabón ${ }^{209}$ - en el 71 ó 72 a. C. Al margen de la interesante propuesta realizada por el arqueólogo J. Armendáriz acerca de la ubicación del posible campamento de Pompeyo en territorio vascón en el cerro de Santa Cruz de Aranguren, a los pies de la Sierra de Tajonar ${ }^{210}$, parece claro que debió ser en esta tercera fase de la conquista cuando, efectivamente, Roma empezó a tener conocimiento de otros importantes centros de los Vascones, no sólo de los que debían rodear el curso central del río Arga en torno a la futura Pompelo sino seguramente también de los que controlaban el curso medio de dicho río, en torno a la futura Andelo, y de los que se abrían a la explotación de los recursos de la cuenca media del río Aragón, en torno a Cara. Para todos ellos, como hemos visto, la documentación arqueológica ha constatado niveles de ocupación protohistórica ${ }^{211} \mathrm{y}$, en fecha temprana - hacia el siglo । a. C.- ligeros traslados de población —el más sintomático es el de Santacara donde la nueva ciuitas de los Carenses se desplaza apenas unos metros hacia el Sur buscando una mejor situación sobre la vega del río Aragón-así como la incorporación del nuevo modelo urbanístico ortogonal y de «ciudades en llano", elementos todos que demuestran la definitiva crisis - o, cuando menos readaptación- del modelo indígena de ocupación del territorio ${ }^{212}$. Este constituye, sin duda, el segundo gran hito en la urbanización de las ciuitates de los Vascones. Mosaicos como el conocido de Likine o dedicatorias a la divinidad local Larrahi por un Manilius Martialis - ambos casos procedentes de Andelo- documentan muy bien el cruce de elementos indígenas de raigambre celtibérica y vascónica que debió darse en esta zona de la Navarra Media213.

207 Para la posición de lacca, véase NAVARRo, M., y MAGALlón, M. a A.: «Las ciudades del Prepirineo Occidental y Central en época alto-imperial: sus habitantes y su status», GonzÁlez, J. (ed.): Ciudades Privilegiadas en el Occidente Romano. Sevilla, 1999, págs. 61-84, esp. Pág. 73, nota 26 y para la de Segia Magallón, M. ${ }^{a}$ A.: op. Cit. (n. 28), págs. 39-40.

208 Con todos los elementos que centran la discusión, véase: PINA, F.: «Deportaciones como castigo e instrumento de colonización durante la República Romana. El caso de Hispania», en MARCO, F., PINA, F., y REMESAL, J. (eds.): Vivir en tierra extraña: emigración e integración cultural en el mundo antiguo. Barcelona, 2004, págs. 211-246, esp. Págs. 236-237. ${ }^{209}$ STR., IV, 10.

210 ARMendáRIZ, J.: Propuesta de identificación..., págs. 42-48.

211 Castiella, A.: Peculiaridades del poblamiento..., págs. 211-212 (para el entorno de Pompelo), 212-213 (para el de Andelo) y 214 (para el de Cara), abundando en las noticias que para esta última diera en La Edad del Hierro..., págs. 122.

212 ARMENDÁRIZ, J.: El proceso de formación..., págs. 630-633.

213 Para la inscripción de Andelo, véase Mezquíriz, M. ${ }^{a}$ A.: Placa de bronce..., págs. 185-186 y para la dedicatoria HEp3, 262. Para ambos testimonios: VeLAZA, J.: op. Cit. (n. 69), págs. 626-630. 
Resulta sugerente la reciente propuesta de J. J. Sayas ${ }^{214}$ de -a partir de la cronología de las menciones a comunidades vásconas en las fuentes literarias-considerar la época augústea como la de creación de las ciuitates de lluberi o de Aracilum orientadas, a su juicio, a controlar importantes vías de comunicación. La documentación arqueológica, hasta la fecha, nada puede refrendar al respecto pues es muy amplia la cronología de materiales con que se cuenta para la segunda y los de la primera - bastante escasos- no son anteriores al siglo II d. C. Fuera en época augústea o algo antes, es evidente que en el lapso entre las guerras sertorianas y el de la época del Naturalista ya existen en la parte meridional del ager Vasconum $^{215}$ comunidades de derecho latino y de derecho romano en Calagurris, Cascantum y Gracchurris. Precisamente, la documentación arqueológica documenta para esta última un notable florecimiento arqueológico coincidente con el momento en que -además - como prueba de su autonomía política acuña ases y semises con la leyenda MVNIC. GRACVRRIS ${ }^{216}$. En esta época se vive en Gracchurris, como ha resumido J. A. Hernández Vera ${ }^{217}$, toda una activísima labor de transformación urbanística quizás paralela, además, a la recepción de su estatuto municipal y que incluye la construcción de un complejo hidráulico, la edificación de varias domus nuevas y la de un complejo industrial quizás destinado a la producción de aceite. Al mismo tiempo, parece que los edificios de espectáculos de Calagurris muestran una ferviente actividad lúdica como demuestran los testimonios cerámicos que en su lugar referimos ${ }^{218}$. Ambos casos son un buen ejemplo de la edilicia pública vinculada a los momentos subsiguientes a la promoción política de comunidades, que recientemente ha estudiado para el caso hispano B. Goffaux ${ }^{219}$.

Sin embargo, si se analizan los ritmos cronológicos de la monumentalización de las ciuitates del solar vascón resumidos en la Tabla II llama la atención que la mayor parte de las obras públicas que afectan a éstas tienen lugar entre los siglos I y II d. C., en un arco cronológico comprendido entre la época Julio-Claudia y el periodo de Trajano-Adriano y que afecta, además, a uno de los periodos claves de la historia de la España antigua: la época Flavia. Precisamente gracias a Plinio conocemos la singularísima y muy extraordinaria decisión vespasiánea de otorgar el Latium uniuersae Hispaniae ${ }^{220}$. Entre los resultados derivados de la misma, la promoción a municipia Latina de las comunidades beneficiadas - todas las hispanas que no disfrutaran ya de condición privilegiada - generó un activísimo proceso de monumentalización ${ }^{221}$ para el que no faltan testimonios en territorio vascón.

214 SaYAS, J. J.: El municipio de Vasconia..., (en prensa), s. págs., y Protohistoria e historia..., pág. 99.

215 PLIN., HN. IV, 20, 110.

216 Para una síntesis de las acuñaciones puede verse PERÉX, M. a J.: op. Cit. (n. 8), pág. 153.

217 Hernández Vera, J. A.: op. Cit. (n. 8), págs. 179-182.

218 Véase nota 153, en este mismo trabajo.

219 Goffaux, B.: «Promotions juridiques et monumentalisation des cités hispano-romaines», Salduie, 3, (2003), págs. 143-162.

220 PLIN. HN., III, 3, 30.

221 El tema puede verse —en el contexto general de toda Hispania - en Andreu, J.: Edictum, municipium..., págs. 169-179 y —de forma más parcial, para la prouincia Hispania Citerior y para el co- 
Así, como ha apuntado F. Beltrán Lloris ${ }^{222}$, del mismo modo que la epigrafía empieza a traslucir los resultados de este proceso de integración con la aparición de individuos adscritos a la Quirina tribus - casos del Segiensis L. Post(umius) Flaccus, y de los Atilii C. Atilius Genialis y L. Atilius Festus ${ }^{223}$ - la documentación arqueológica manifiesta ya la presencia pública de miembros de la elite local —os Aemilii en Andelo y los Atilii en Tarraca ${ }^{224}$ _; la participación de magistrados, aediles, en la erección de un templo Apollini Aug(usto) en Andelo225; la reestructuración urbanística del centro cívico de $P_{0}$ melo ${ }^{226}$ o la reforma de algunas viviendas en Andelo $^{227}$; la dotación de obras hidráulicas y de espacios públicos en Tarraca ${ }^{228}$; la restauración del edificio singular de $\operatorname{Cara}^{229}$; y el florecimiento comercial, y también de las infraestructuras a él asociadas, del puerto de Oiasso ${ }^{230}$, comunidades todas para las que no debería dudarse de su condición de municipia Flauia. Para otros casos, como el del embellecimiento de algunas viviendas - como la del solar de «La Clínica», en Calagurris ${ }^{231}$ — ciudad que disfrutaba de condición privilegiada desde época bien temprana- habría que buscar la explicación en el efecto de competitividad y de emulación que está atestiguado afectó a comunidades ya de antiguo privilegio - un caso paradigmático es el de la propia capital provincial, Ta$r \mathrm{raco}^{232}$ - volcadas ahora en desarrollar programas constructivos que no desentonaran frente a la monumentalización de que comenzaban a hacer gala con orgullo los nuevos municipia Flauia vecinos. Así mismo, de igual modo que en otros puntos de la prouincia Hispania Citerior antiguas ciuitates como Emporiae entran ahora en decadencia incapaces de competir con el esplendor de municipa Flauia próximos como Egara o Aquae Calidae ${ }^{233}$, parece que ésta es también la fecha de

nuentus Caesaraugustanus- en «Construcción pública y municipalización en la prouincia Hispania Citerior: la época Flavia», Iberia, 7, (2005), págs. 37-75 e Incidencia de la municipalización..., págs. 163-185.

222 Beltrán lloris, F., Martín Bueno, M., y Pina, F.: op. Cit. (n. 82), págs. 90-93.

${ }^{223} \mathrm{CIL}, \mathrm{II}, 2981$ y CIL, II, 2973 de Asín —cerca de Ejea de los Caballeros-y de Sádaba respectivamente.

224 Véase, al respecto, notas 86 y 182 del presente trabajo.

225 Véase nota 127, con referencia a la inscripción que documenta el, hasta el momento, único caso seguro de comportamiento munificente de la elite documentado en territorio vascón (ANDREU, J.: op. Cit. (n. 6), pág. 183, nota 15)

${ }^{226}$ Martín Bueno, M.: op. Cit. (n. 61), págs. 113-114.

${ }^{227}$ La casa del Triunfo de Baco, según MeZquíRIz, M. ${ }^{a}$ A.: Andelos: secuencia estratigráfica..., pág. 521 sobre todo a partir de la datación propuesta para el mosaico, que puede estudiarse de forma monográfica en Mezquiriz, M. ${ }^{a}$ A.: «Mosaico báquico hallado en Andelos», Rev. Arq., 77, (1987), págs. 59-61.

${ }^{228}$ Aunque se ha dado bibliografía al respecto, puede verse también, en el contexto de los efectos de la excepcional medida de Vespasiano Beltrán Lloris, F., Martín Bueno, M., y Pina, F.: op. Cit. (n. 82), págs. 92-93.

${ }_{229}$ Véase MezquíRIz, M. ${ }^{\text {a }}$ A.: Primera campaña..., pág. 109.

${ }^{230}$ Fernández OCHOA, C., y MoRiLlo, A.: op. Cit. (n. 8), págs. 151 y 187-188, que lo integran, además, en la política de privilegio y explotación intensiva del territorio abierto al Cantábrico desarrollada por los Flavios para el que aportan más testimonios de otras ciuitates ajenas al territorio que centra nuestro trabajo.

${ }^{231}$ ESPINOSA, U.: op. Cit. (n. 8), págs. 134-137.

${ }^{232}$ DUPRÉ, X.: «Un gran complejo provincial de época flavia en Tarragona: aspectos arqueológicos», en Stadtbild und Ideologie. Die Monumentalisierung hispanischen Städte zwischen Republik und Kaiserzeit. Munich, 1990, págs. 311-325, esp. Págs. 318-322.

${ }^{233}$ Alföldy, G.: «Spain», en Bowmann, A. K., Garnsey, P., y Rathbone, D. (eds.): The Cambridge Ancient History. XI. Cambridge, 2000, págs. 444-461, esp. Pág. 461. 
la crisis de Gracchurris, que es progresivamente abandonada en beneficio de las uillae del entorno ${ }^{234}$.

Volviendo a las fuentes, entre la fecha de las noticias plinianas sobre los populi del conuentus Caesaraugustanus y las noticias de la Geographiké Hyphegésis de Ptolomeo algunas comunidades - como lluberi, sino es que Ptolomeo, según propuesta reciente de J. L. Ramírez Sádaba la esté refiriendo como Biturí ${ }^{235}$ — han desaparecido - quizás sometidas a procesos de contributio que las han unido a comunidades vecinas ${ }^{236}$ - y para otras es ahora cuando contamos con su primera mención —casos de Nemanturista; Curnonium; Ergauia; o Muskaria—, quizás porque fue en época Flavia cuando - reagrupando antiguos poblados menoressurgieron como último eslabón del proceso de urbanización del territorio vascón. La falta de datos arqueológicos bien datados para todas ellas e incluso las dudas que aun existen para su definitiva ubicación geográfica nos impiden extraer más conclusiones al respecto si bien la epigrafía y algunos materiales arqueológicos del solar que hemos propuesto para la Nemanturista ptolemaica encajarían bien - como hemos visto- con el perfil propio de una comunidad ya municipalizada, con un amplio hinterland de influencia y, sobre todo, con unas elites ávidas de mostrar su poder social y político a través del recurso en sus enterramientos a elementos iconográficos y suntuarios netamente romanos y típicos del horizonte de autorepresentación de la elite.

Aunque durante el siglo II d. C. todavía están documentados algunos episodios constructivos en las ciuitates que venimos estudiando, es el ámbito rural el que entonces adquiere una mayor importancia. Villae como las de Liédena, Arellano, o ViIlafranca, en Navarra, y Campo Real, en el límite entre Navarra y Aragón, empiezan ahora a funcionar ${ }^{237}$ al tiempo que los conjuntos epigráficos de algunos núcleos rurales — caso de Sofuentes, por ejemplo238 - manifiestan, como se ha dicho, una activa sintonía con las modas epigráficas de la ciudad.

A partir de esa fecha observaremos pues una notable transformación del poblamiento: apenas se acometen nuevos programas constructivos —aun así, hay

${ }^{234}$ V. V. A. A.: op. Cit. (n. 164), págs. 155-159.

235 Ramírez SÁdABA, J. L.: Las ciudades vasconas..., (en prensa), s. pág.

${ }^{236}$ Sobre este procedimiento, usual en procesos de municipalización, puede verse LAFFI, U.: Adtributio e contributio. Problemi del sistema politico-amministrativo dello stato romano. Pisa, 1966, págs. 158165.

${ }^{237}$ Para la cronología de las uillae del territorio navarro puede verse: Mezquíriz, M. ${ }^{a}$ A.: «Los mosaicos de la villa romana de Liédena (Navarra), PV, 67, (1957), págs. 9-35, «Hallazgos de mosaicos romanos en Villafranca (Navarra)», PV, 124-125, 1971, págs. 177-188; "La villa romana de San Esteban, Falces», TAN, 4, (1985), págs. 159-184, y La villa romana de Arellano. Pamplona, 2003. El caso de Campo Real - que es sólo conocido a través de prospecciones y a partir de los materiales que en ellas se han obtenido (un inventario de los mismos puede verse en MARTín BUENO, M.: Aragón arqueológico: sus rutas. Zaragoza, 1982, págs. 176-177- es fechado así por Marcos Pous, A., y CAstielLA, A.: op. Cit. (n. 92), pág. 135.

${ }_{238}$ Para la cupa véase: AE, 1977, 483. Para el conjunto epigráfico de Sofuentes y los elementos que aporta para el conocimiento de la sociedad romana de esta zona del territorio de los Vascones, véase ANDREU, J.: Ciudad y territorio..., págs. 200-202. 
constancia fehaciente de ellos en Calagurris pero seguramente obra de la iniciativa pública ${ }^{239}$, en Pompelo, donde se construyen las termas ${ }^{240}$, y en lacca, donde se levanta un posible macellum ${ }^{241}$, se abandonan algunos vetustos edificios ya obsoletos - algunas viviendas de $A$ Andelo ${ }^{242}$, por ejemplo-, se interrumpen los registros epigráficos urbanos - caso de Andelo, uno de los conjuntos epigráficos mejor conocidos $^{243}-y$, en definitiva, se vive un proceso que anticipa el abandono de algunos centros en época tardía o, al menos, la amortización y reaprovechamiento para nuevos usos de antiguos edificios. Este hito, que tendría un primer testimonio en la necrópolis de Oiasso - que en la segunda mitad del siglo II d. C. superpondrá a la misma un posible templo 244 - su continuidad en la apresurada y urgente fortificación de Pompelo - con los correspondientes niveles de incendio detectados en la ciudad, fenómenos ambos fruto de las primeras invasiones ${ }^{245}-\mathrm{y}$ su última manifestación también en la supuesta capital de los Vascones, que, ya en el siglo IV d. C. cambiará notablemente su organización urbanística, como ha estudiado M. ${ }^{a}$ A. Mezquíriz ${ }^{246}$ es, sin duda, el último eslabón del proceso urbanizador que aquí hemos pretendido abordar. Entretanto, la ciudad - extendida por todos los rincones del Imperio: ubique res publica, escribiría Tertuliano ${ }^{247}$ - había asistido a un profundo proceso de transformación e incluso de conversión ideológica - de sede del poder político a sede episcopal, en algunos casos- y el ager-antes elemento activo en la configuración de los territoria municipales- se había transformado ahora en centro de la vida y de la actividad económica y en espejo y reflejo del poder de las elites locales -ahora de grandes possesores-, asunto éste que, sin embargo, y como fácilmente se comprenderá queda para el estudio de los medievalistas.

Tudela de Navarra, primavera de 2006

239 Posible monumentalización del circo documentada en HEp10, 420. Quizás en este contexto hay que situar también la perdida lápida HEp1, 497, a la que nos referimos con anterioridad, dada la titulatura imperial en ella referida.

240 Unzu, M., Prieto, P., Peréx, M. a J., y Hernando, A.: op. Cit. (n. 89), pág. 445.

241 OnA, J. L., Paz, J., Pérez, J. A., y De Sus, M. ${ }^{a}$ L.: op. Cit. (n. 8), pág. 15.

242 Mezquíriz, M. ${ }^{a}$ A.: Actividad arqueológica..., pág. 331.

243 VelazA, J.: op. Cit. (n. 69), pág. 640.

244 Rodríguez Salís, J.: op. Cit. (n. 145), pág. 152.

245 Para la muralla de Pompelo, véase, en este mismo trabajo, nota 94 y para los niveles de incendio

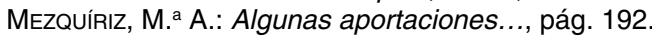

246 MeZquíriz, M. a A., y TABAR, I.: Excavaciones arqueológicas..., pág. 312.

247 TERT., De anim., 30, 3c. 


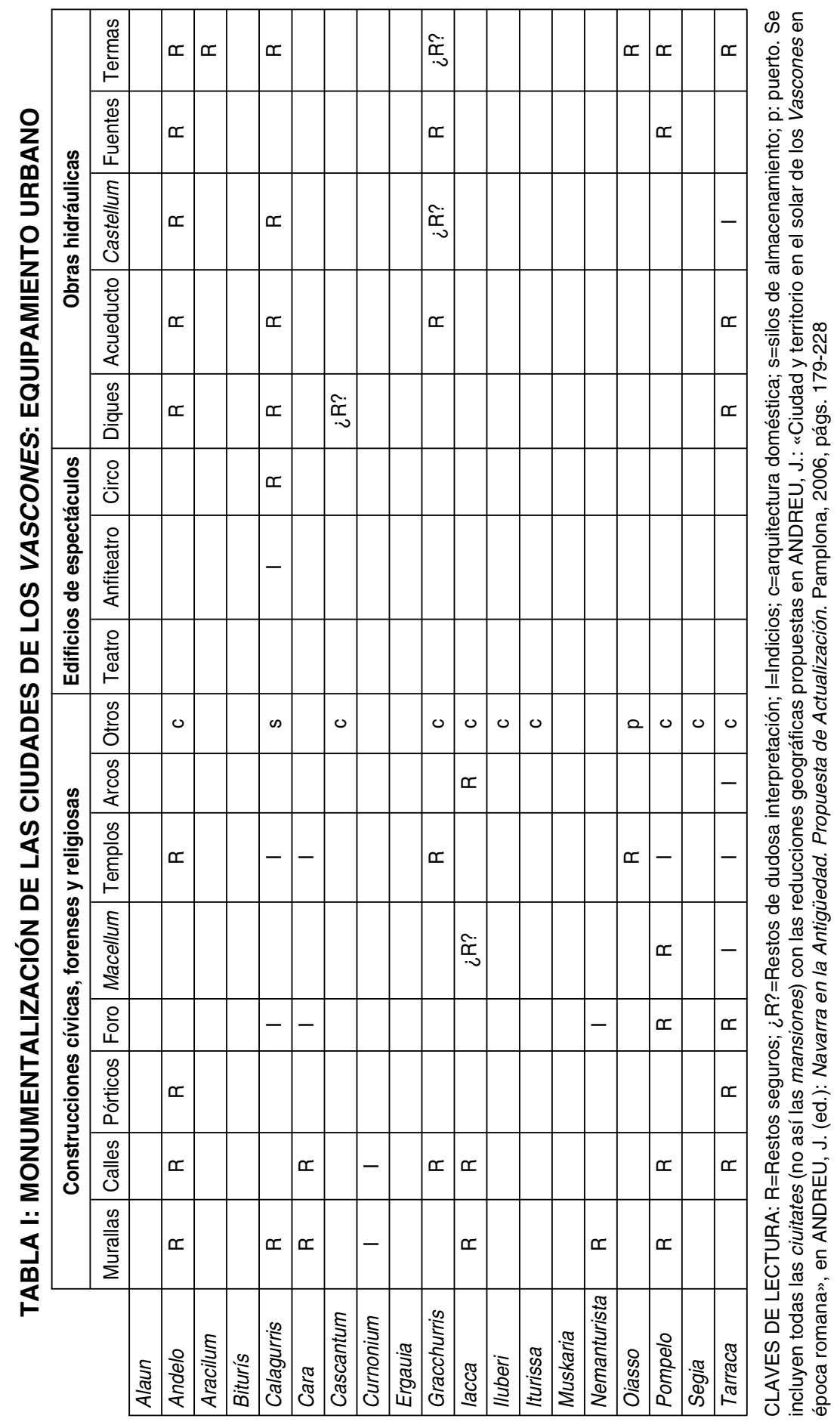


BIBLIOGRAFÍA: Andelo: murallas (TARACENA, B., y VÁZQUEZ DE PARGA, L.: «Excavaciones en Navarra. V. La Romanización», PV, 24, (1946), pág. 424 y MEZQUÍRIZ, M. ${ }^{a}$ A.: «Andelos: Secuencia estratigráfica y evolución cronológica», PV, [Anejo 7], (1987), pág. 528), calles (MEZQUíRIZ, M. ${ }^{a}$ A.: «Actividad arqueológica en Navarra (1986-87), Andelos", TAN, 7, (1998), pág. 331), pórticos (PERÉX, M. a J.: Los Vascones, el poblamiento en época romana. Pamplona, 1986, pág. 85), templos (a juzgar por la inscripción AE, 1989, 486 Apollini Augusto), viviendas (MEZQUÍRIZ, M. ${ }^{a}$ A.: Andelos: Secuencia estratigráfica..., pág. 521-528), dique-acueducto-castellum (MEZQUÍRIZ, M. ${ }^{a}$ A. y UNZU, M.: «De hidráulica romana: el abastecimiento de agua a la ciudad romana de Andelos", TAN, 7, (1988), págs. 238-241; 247-258; y 244-247/258-265), fuente (MEZQUíRIZ, M. ${ }^{a}$ A.: «La ciudad de Andelos (Mendigorría)», TAN,

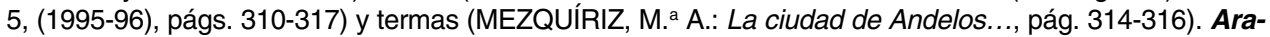
cilum: en Santa María de Zamarce según noticia de Diario de Navarra, 25-8-2005. Calagurris: murallas (GÓMEZ-PANTOJA, J.: «La ciudad romana de Calahorra», en Symposion de Ciudades Augusteas. II. Zaragoza, 1976, pág. 187), foro (en el espacio público-religioso actual de El Raso, según ESPINOSA, U.: Calagurris lulia. Calahorra, 1984, pág. 112), templos (a juzgar por las piezas estatuarias de Júpiter y de Afrodita, según ESPINOSA, U.: Calagurris..., págs. 116-118), silos y viviendas (según ESPINOSA, U.: Calagurris..., págs. 115 y 134-137), anfiteatro (a partir de la imagen de un gladiador secutor en BELTRÁN, M.: «Ludus Calagurritanus: relaciones entre el municipium Calagurris lulia y la colonia Victrix lulia Celsa", en Calahorra. Bimilenario de su fundación. Calahorra, 1984, págs. 129-138 y quizás fosilizado en el área de la Casa Santa, según GONZÁLEZ BLANCO, A.: «El anfiteatro de Calahorra», Kalakorikos, 3, (1998), págs. 194-195), circo (en El Mercadal, según PIERNAVIEJA, P.: «Los circos de Hispania", en Segovia. Symposion de Arqueología Romana. Barcelona, 1977, pág. 316 y 321 y con mención a ludi circienses en HEp7, 589 del alfar calagurritano de La Maja), dique-acueducto-castellum (MEZQUÍRIZ, M. ${ }^{a}$ A.: «El acueducto de Alcanadre-Lodosa», TAN, 1, (1979), págs. 143-145), y termas (con indicios comentados por MARTíN BUENO, M., y CANCELA, M. ${ }^{a}$ L.: "Arqueología clásica de Calahorra y su entorno», en Calahorra. Bimilenario..., pág. 87 y restos estudiados por LUEZA, R. A.: «Termas Romanas en el municipium Calagurris lulia», en FERNÁNDEZ OCHOA, C., y GARCíA, V. (eds.): Termas Romanas en el Occidente del Imperio. Gijón, 2000, págs. 185-189). Cara: muralla (MEZQUÍRIZ, M. ${ }^{a}$ A.: «Primera campaña de excavaciones en Santacara (Navarra)», PV, 138-139, (1975), pág. 84), calles (con

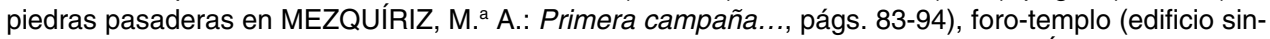
gular monumental con hallazgo de retrato masculino y 'calceus' de bronce: MEZQUÍRIZ, M. ${ }^{a}$ A.: «Hallazgo de un 'calceus' de bronce en Santacara, en Bronces y Religión Romana. Madrid, 1993, págs. 301302 y «Retrato masculino aparecido en las excavaciones de Santacara (Navarra)», PV, 137, (1974), págs. 403-405). Cascantum: casa (romano-republicana con pavimento de opus signinum en MEZQUíRIZ, M. ${ }^{a}$ A.: «Descubrimiento de pavimentos de 'opus signinum en Cascante (Navarra)», en Homenaje a D. José Esteban Uranga. Pamplona, 1971, pág. 278). Curnonium: murallas-calles (indicios fruto de las prospecciones desarrolladas por ARMENDÁRIZ, J.: «Bases arqueológicas para la localización de la ciudad vascona de Curnonium en Los Arcos (Navarra)", TAN, 19 (2006), págs. 85-108 y noticias antiguas recogidas por QUINTANILLA, E.: La Comisión de Monumentos Históricos y Artísticos de Navarra. Pamplona, 1995, pág. 318). Gracchurris: calles (MARTíNEZ, J. M.: «Alfaro. Excavaciones arqueológicas en las Eras de la Cárcel. Campaña de 1996», Estrato, 8, (1997), pág. 58), templos (NÚÑ̃EZ, J.: «La arquitectura pública de época romana en el País Vasco y sus áreas geográficas limítrofes: una aproximación crítica", Iberia, 1, (1998), pág. 134), viviendas (HERNÁNDEZ VERA, J. A., y CASADO, P.: "Graccurris: primera fundación romana en el valle del Ebro", en Symposion de Ciudades...II. Zaragoza, 1976, pág. 24), acueducto (HERNÁNDEZ VERA, J. A., NÚÑEZ, J., y MARTÍNEZ, J. M.: Excavaciones arqueológicas de Alfaro. Logroño, 1984, pág. 144), castellum (PERÉX, M. a J.: Los Vascones..., pág. 157), fuentes (V. V. A. A.: Graccurris: conjuntos monumentales en la periferia urbana: puentes, presas, ninfeos. Graccurris 4. Logroño, 1995), termas (supuestas por MARTíNEZ, J. M.: Alfaro. Excavaciones arqueológicas..., pág. 59). lacca: murallas (quizás de época ibérica, según PAZ, J.: «Solar del antiguo Colegio de los PP. Escolapios (Jaca, Huesca), Arqueología Aragonesa. 1986-1987. Zaragoza, 1981, págs. 333-335), calles (JUSTE, M. N.: «Excavaciones en el solar de la C/7 de Febrero de 1893-esquina con la C/Cambras de Jaca», Arqueología Aragonesa. 1990. Zaragoza, 1992, págs. 271-274), macellum (ONA, J. L., PAZ, J., PÉREZ, J. A., y DE SUS, M. ${ }^{a}$ L.: Arqueología Urbana en Jaca: el solar de las Escuelas Pías. Zaragoza, 1987), arcos (PAZ, J.: Solar del antiguo Colegio..., pág. 334), y casas (con síntesis en BELTRÁN, M.: «La ciudad clásica en Aragón», en LACARRA, C. (ed.): Difusión del Arte Romano en Aragón. Zaragoza, 1996, págs. 67-68). Iluberi: viviendas (noticias de ALTADILL, J.: «De re geographica-histórica. Vías y vestigios romanos en Navarra», en Homenaje a D. Carmelo... Pamplona, 1928, pág. 462, 
después analizadas en CASTIELLA, A.: Por los caminos romanos de Navarra. Pamplona, 2003, pág. 99). Iturissa: arquitectura doméstica (PERÉX, M. ${ }^{a}$ J., y UNZU, M.: «Necrópolis y poblado de época romana en Espinal (Navarra)", TAN, 13, (1997-98), págs. 80-81). Nemanturista: muralla (ARMENDÁRIZ, R. M. ${ }^{a}$, MATEO, M. ${ }^{a}$ R., y SÁEZ DE ALBÉNIZ, M. ${ }^{\text {a }}$ P.: «Primera campaña de excavación en el yacimiento de Santa Criz (Eslava-Navarra)", TAN, 12, (1995-96), pág. 323) y foro (en la plataforma del cerro, según ARMENDÁRIZ, R. M. ${ }^{a}$, MATEO, M. ${ }^{a}$ R., y SÁEZ DE ALBÉNIZ, M. ${ }^{a}$ P.: «Santa Criz, una necrópolis romana de incineración en Eslava (Navarra)", Isturitz, 9, (1997), pág. 828). Oiasso: templo (sobre antigua necrópolis, en FERNÁNDEZ OCHOA, C., y MORILLO, A.: De Brigantium a Oiasso. Una aproximación al estudio de los enclaves marítimos cantábricos en época romana. Madrid, 1994, págs. 149-150), puerto (GEREÑU, M., LÓPEZ, M. ${ }^{a}$ M., y URTEAGA, M. ${ }^{a}$ M.: «Novedades de arqueología romana de Irún-Oiasso. 1992-96", Isturitz, 8, (1997), págs. 471-473), y termas (GEREÑU, M., LÓPEZ, M. ${ }^{a}$ M., y URTEAGA, M. ${ }^{a}$ M.: Novedades de arqueología..., pág. 476). Pompelo: murallas (MEZQUÍRIZ, M. ${ }^{a}$ A.: La excavación estratigráfica de Pompaelo. I. Campaña de 1956. Pamplona, 1958, págs. 220-223), calles (MEZQUÍRIZ, M. ${ }^{a}$ A.: «Algunas aportaciones al urbanismo de Pompaelo», en Symposion de Ciudades Augusteas. Zaragoza, 1976, págs. 191-193), foro (cerca de la Catedral, en MEZQUíRIZ, M. ${ }^{\text {a } A .: ~ « P a m p l o n a, ~ c i u d a d ~ r o-~}$

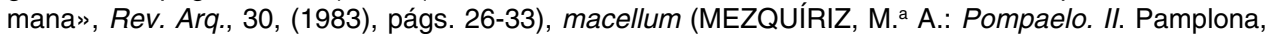
1978, pág. 31-33), templos (con todos los indicios en PERÉX, M. a J.: Los Vascones..., págs. 204-205),

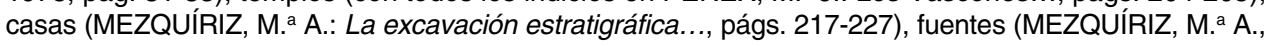
y TABAR, I.: «Excavaciones arqueológicas en la catedral de Pamplona», TAN, 11, (1993-94), pág. 312), y termas (UNZU, M., PRIETO, P., PERÉX, M. J., y HERNANDO, A.: «Roman Baths in Pamplona (Navarra, Spain)", en Babels. Anual Papers on Mediterranean Archaeology. 'Cura Aquarum'. Leiden, 2006, págs. 441-445). Segia: casas (apenas un nivel de habitación en LANZAROTE, M. ${ }^{a}$ P.: «Excavaciones arqueológicas en la Plaza de Santa María, Ejea de los Caballeros (Zaragoza)", Suessetania, 13, (1993), págs. 76-77). Tarraca: calles (de subida a EI Pueyo en GALIAY, J.: La dominación romana en Aragón. Zaragoza, 1946, pág. 80 y en torno al foro en BELTRÁN, F.: «El planteamiento urbano de Los Bañales», en Symposion de Ciudades.... II. Zaragoza, 1976, pág. 162), pórticos-foro (JIMÉNEZ, J. L.: Arquitectura forense en la Hispania Romana. Zaragoza, 1978, págs. 100-101), macellum (¿posible área de tabernae bajo espacio porticado en el foro?, según noticia de BELTRÁN, A.: «Las obras hidráulicas de Los Bañales (Uncastillo, Zaragoza)", en Segovia. Symposion de Arqueología Romana. Barcelona, 1977, pág. 100), templos (confusas noticias de GALIAY, J.: Las excavaciones del Plan Nacional de Los Bañales de Sádaba (Zaragoza). Madrid, 1944, pág. 28), arco (noticia de LABAÑA, J. B.: Itinerario del Reino de Aragón, Madrid [edición Diputación de Zaragoza, Zaragoza, 1895] 1610, pág. 302, después comentada por BELTRÁN, M.: «Roma: República y Alto Imperio», en Estado Actual de la Arqueología en Aragón. I. Ponencias. Zaragoza, 1990, pág. 236), casas (en el foro, según BELTRÁN, F.: El planteamiento urbano..., pág. 162 - quizás mejor tabernae - y en El Pueyo, según BELTRÁN, F.: «Sobre las últimas excavaciones en EI Pueyo de Los Bañales (Uncastillo, Zaragoza)", en XIV Congreso Nacional de Arqueología (Vitoria, 1975). Zaragoza, 1977, pág. 1058), dique (MARTín BUENO, M.: «Dique romano en Cinco Villas", Miscelánea Arqueológica al Profesor Antonio Beltrán. Zaragoza, 1975, pág. 252, quizás de uso agrícola), acueducto-termas (BELTRÁN, A.: Las obras hidráulicas..., págs. 94-101 y 102-118 respectivamente), castellum (indicios en grandes balsas próximas a las termas, al pie de El Pueyo, y al Oeste del foro). 


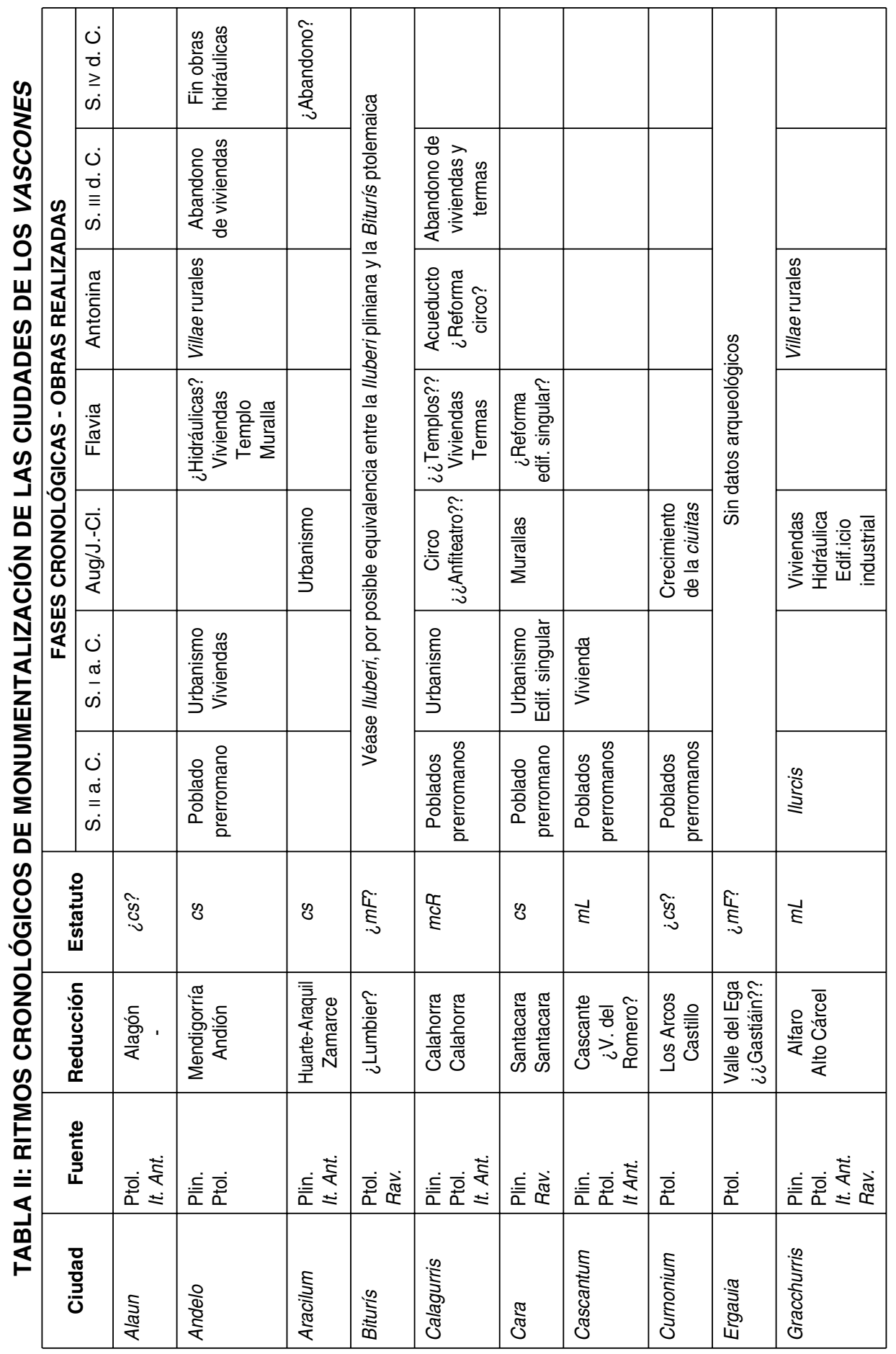




\begin{tabular}{|c|c|c|c|c|c|c|c|c|c|}
\hline $\mid \begin{array}{l}\dot{0} \\
\dot{0} \\
\geq \\
\dot{0}\end{array}$ & 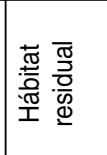 & & & & & & 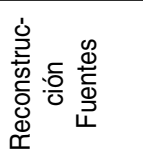 & & \\
\hline 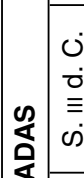 & 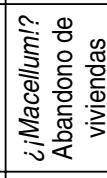 & & & & & & 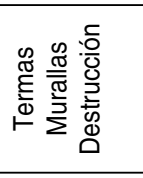 & & \\
\hline 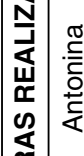 & & 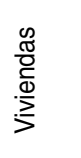 & & "̊ & & & 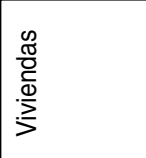 & & 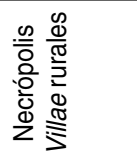 \\
\hline 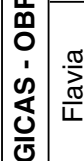 & & & 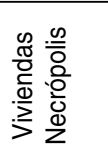 & $\begin{array}{l}\frac{0}{0} \\
\frac{0}{0} \\
\frac{0}{0} \\
\frac{0}{0} \\
0 \\
0 \\
\frac{0}{0}\end{array}$ & \begin{tabular}{|l}
0 \\
0 \\
$\frac{0}{0}$ \\
0 \\
09 \\
$\frac{1}{20}$ \\
2
\end{tabular} & 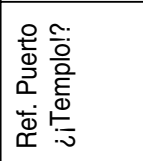 & 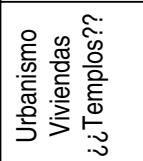 & & ․: \\
\hline 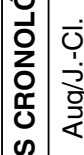 & 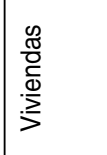 & & 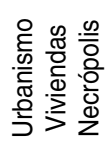 & ๘ & & 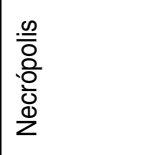 & 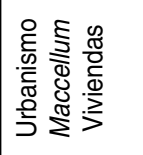 & $\begin{array}{l}0 \\
\frac{\pi}{0} \\
\frac{0}{0} \\
.0 \\
\sum\end{array}$ & \\
\hline 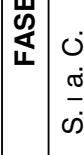 & & & & & & & 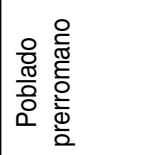 & & \\
\hline $\begin{array}{l}\dot{0} \\
\dot{\sigma} \\
=\dot{0}\end{array}$ & 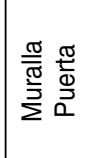 & & & & & & 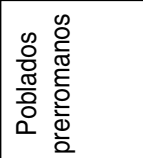 & & 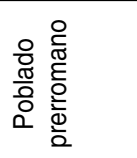 \\
\hline 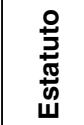 & $\mathscr{O}$ & $\begin{array}{l}\tilde{o} \\
\tilde{v} \\
\dot{y} \\
\tilde{c}\end{array}$ & 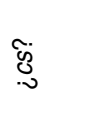 & ${ }_{\text {ह }}^{\tilde{E}}$ & है & 8 & 8 & $y$ & ד \\
\hline 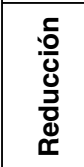 & 胥 & 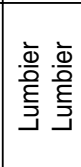 & 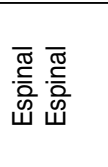 & 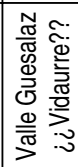 & 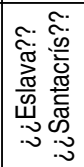 & 르 으 & 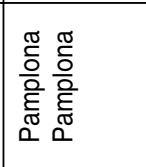 & 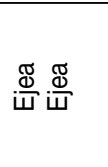 & 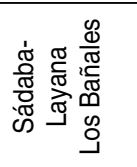 \\
\hline 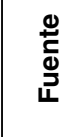 & 兵产 & $\stackrel{\dot{\underline{\underline{a}}}}{\mathrm{a}}$ & 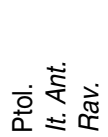 & के & $\frac{\dot{0}}{0}$ & 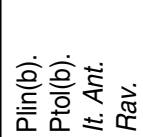 & 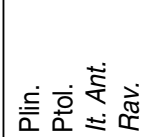 & 皇高这 & 兵高这 \\
\hline 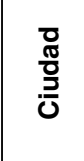 & 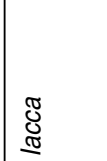 & $\begin{array}{l}\frac{1}{\bar{\phi}} \\
\stackrel{3}{=}\end{array}$ & 芯 & 竞 & 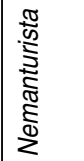 & 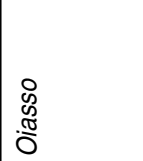 & 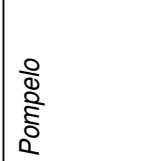 & क & $\frac{\sqrt{\pi}}{\stackrel{\pi}{\mathbb{2}}}$ \\
\hline
\end{tabular}


CLAVES DE LECTURA: FUENTE (sólo Plinio, Ptolomeo y los Itinerarios: para otras fuentes véase: PERÉX, M. ${ }^{a}$ J.: Los Vascones..., págs. 71-232 o, a modo de síntesis, ANDREU, J.: Ciudad y territorio...): It. Ant.: Itinerario de Antonino; Plin: Plinio (HN. III, 3, 24); Plin(b).: Plinio (HN. III, 3, 20 y IV, 20, 110); Ptol. (II, 6, 67); Ptol(b): (II, 6, 10 y II, 7, 2); Rav.: Cosmógrafo de Ravena. REDUCCIÓN: Alagón=Reducción segura o bastante probable; ¿Lumbier?=Reducción probable a espera de más argumentos para su confirmación; ¿¿Gastiáin??=Hipótesis verosímil de reducción. ESTATUTO: ¿cs?=supuesta ciuitas stipendiaria, que cuando es citada por Ptolomeo se ha transformado ya en municipium Latinum Flauium o, sencillamente, funciona como mansio viaria y Ptolomeo la cita como pólis; $c s=$ ciuitas stipendiaria hasta época Flavia en que recibe el derecho latino y se convierte en $m u$ nicipium Latinum Flauium; $m F=$ =estatuto anterior desconocido, ¿municipium Flauium cuando es citada por Ptolomeo?; cs - ¿a?=ciuitas stipendiaria en Plinio y ausente en Ptolomeo, quizás por adtributio con comunidades mayores del entorno; $m c R=$ municipium ciuium Romanorum; $m L=$ municipium Latinum (Latium uetus en Plinio); cf=ciuitas foederata en Plinio, después municipium Latinum Flauium. FASES CRONOLÓGICAS: Poblados perromanos=existencia en el entorno de una serie de oppida que pudieron contribuir a la suma de población previa al origen de la ciuitas; Poblado prerromano=constatación de niveles arqueológicos o indicios de poblamiento prerromano; ¿Hidráulicas?=datación dudosa, o, al menos, con sólo terminus post quem; ¿¿Anfiteatro??=obra pública de la que sólo quedan indicios, noticias indirectas o testimonios antiguos ya perdidos. ¿iMacellum!?=obra pública sobre cuya identificación o interpretación ha habido controversia en la investigación. 


\section{EPIGRAFÍA LATINA EN TERRITORIO DE LOS VASCONES Geografía de los Hallazgos y Conjuntos Epigráficos}

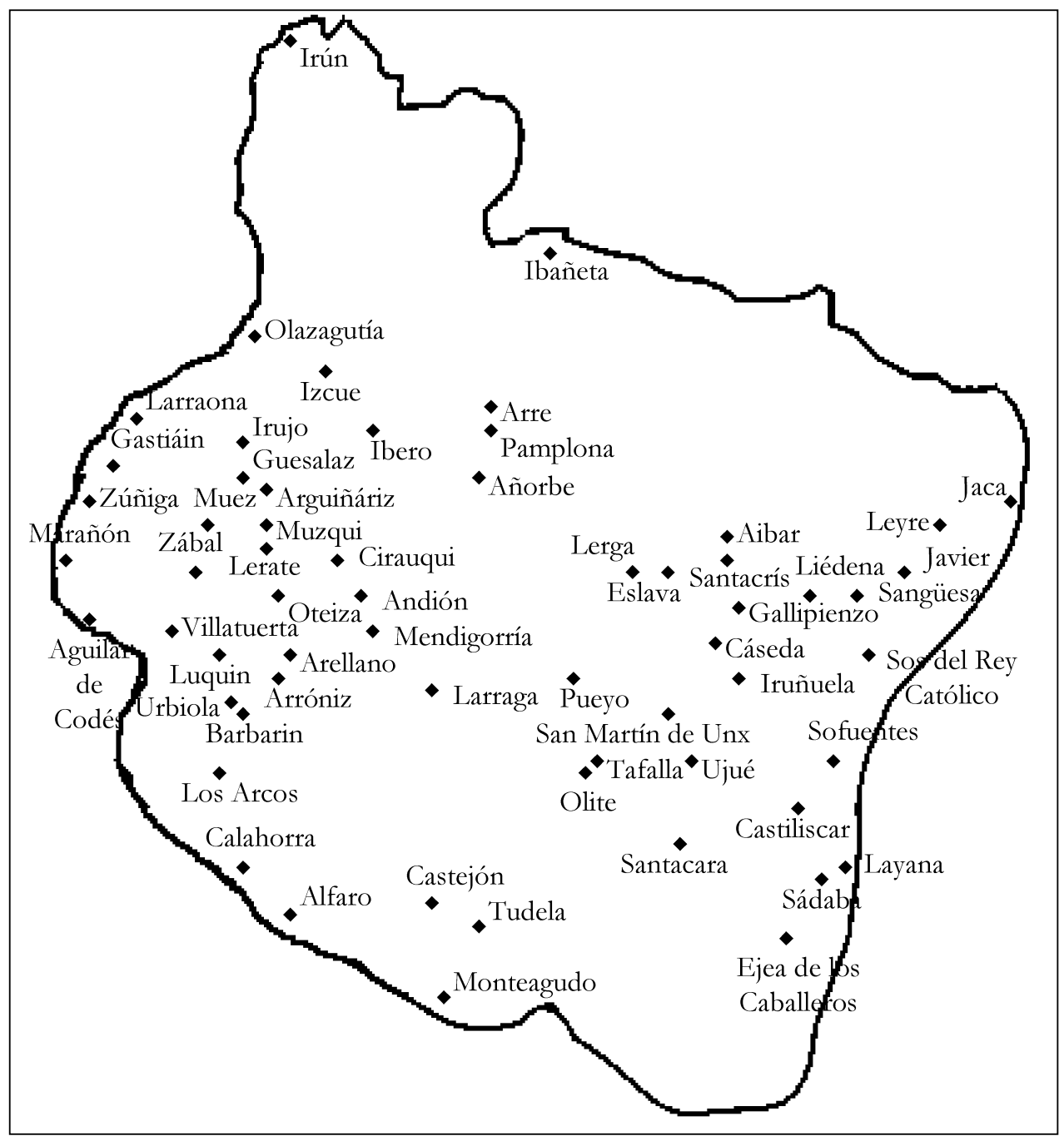




\section{Relación de Documentos Epigráficos y Tipología}

Aguilar de Codés: IRMN, 37; 70; 72; 35; 36 y 69 (funerarias). Aibar: IRMN, 17 (votiva). Alfaro: HEp1, 495 (¿monumental?); HEp6, 790 (miliario) e HEp9, 482 (indeterminada). Andión: AE, 1989, 486 (monumental); CIL, II, 2966 y 2967; HEp3, 263 y 266; IRMN, 73; HEp8, 378, 435 y 436 (funerarias) e HAE, 2101 (indeterminada). Añorbe: IRMN, 5 (miliario). Arellano: IRMN, 18 (carmen epigraphicum). Arguiñáriz: ILER, 865 (votiva). Arre: CIL, II, 2958, 2959 y 2960 (jurídicas). Arróniz: CIL, II, 2972 y AE, 1982, 582 (funerarias). Barbarin: IRMN, 19, 20 y 21 (votivas). Calahorra: CIL, II, 2983; 2984; HEp9, 484 y 579 (funerarias); HEp1, 497; HEp10, 420 (monumentales); HEp7, 577 (miliario) e HEp1, 499 e HEp7, 578 (indeterminadas). Cáseda: HEp8, 372 (votiva). Castejón: VELAZA, J.: Crónica de Epigrafía (II)..., pág. 61 (funeraria) y AE, 1982, 591 (indeterminada). Castiliscar: IRMN, 1; 2; 4; 6; 12; 13 y ERZ, 13 (miliarios). Cirauqui: AE, 1982, 587 (votiva). Ejea de los Caballeros: CIL, II, 2981 e ILER, 6495 (funerarias); LOSTAL, J.: op. Cit. (n. 145), pág. 64 (indeterminada). Eristain: AE, 1993, 1042 (funeraria). Eslava: HAE, 1062; IRMN, 22 (votiva) e IRMN, 67 e HEp3, 253 (funeraria). Gallipienzo: IRMN, 75; HEp8, 373; AE, 1987, 619 (funerarias). Gastiáin: CIL, II, 2970; 2971; 5827; 5828; 5829; 5830; 5831; HEp3, 254; 257; 258; 260; IRMN, 76; 43; 46; 47 y 48 (funerarias) e HEp3, 255; 256; 259 e IRMN, 77 (indeterminadas). Guesalaz: HEp5, 613 (votiva). Ibañeta: IRMN, 23 (votiva). Ibero: CIL, II, 2961 (funeraria). Irujo: HEp8, 374 (votiva). Irún: FITA, F.: "Inscripciones romanas inéditas de Añavieja y Oyarzun", BRAH, 23, (1893), pág. 488 (funeraria). Iruñuela: AE, 1982, 583 (funeraria). Izcue: HEp8, 379 (votiva). Jaca: CIL, II, 2982 (funeraria). Javier: IRMN, 49 (funeraria) y ABÁSOLO, J. A., y ELORZA, J. C.: "Nuevos teónimos de época romana en el País Vasco-Navarro", EAA, 6, (1974), págs. 247-258 (votiva). Layana: CIL, II, 2977; 2978; 2979 y LOSTAL, J.: op. Cit., pág. 89 (funerarias). Larraga: HEp3, 261 (funeraria). Larraona: HEp5, 617; AE, 1982, 584; $585 ; 588 ; 589$ y 590 (funerarias). Lerate: IRMN, 24 y 25 (votivas). Lerga: IRMN, 50 (funeraria). Leyre: IRMN, 26 (votiva). Liédena: IRMN, 51 y 52 (funerarias). Los Arcos: MORET, J. de: op. Cit. (n. 15), pág. 81 (funeraria). Luquin: HEp9, 434 (funeraria). Marañón: IRMN, 53; 54; 55 y 56 (funerarias). Mendigorría: HEp3, 262 (votiva). Monteagudo: CIL, II, 2990 (votiva). Muez: AE, 1951, 283 (funeraria). Muzqui: AE, 1994 y 1052 (votiva). Olazagutía: AE, 1982, 586 (funeraria). Olite: HEp7, 741 (funeraria); 475a; 475b; 475d; 475e; 475f; 475g y 475h (indeterminadas); 474 (votiva) y 472 (¿miliario?). Oteiza: CIL, II, 2968 y 2969 (funerarias) y AE, 1974, 412 (miliario). Pamplona: IRMN, 57 (funeraria). Pueyo: HEp7, 477 e HEp9, 439 (funerarias). Rocaforte: IRMN, 29; 59; SANDOVAL, P.: op. Cit. (n. 114), pág. 4 y CIL, II, 2965 (funerarias). Sádaba: CIL, II, 2973; 2976; 2977; 2978; 6338a; HEp6, 999 y ERZ, 51 (funerarias); 19 y 30 (miliarios). San Martín de Unx: IRMN, 30 y 31 (votivas). Santacara: CIL, II, 2962; 2963; 2964 e IRMN, 68 (funerarias); CIL, II, 4904; 4905; 4906; 4907; 4908; 4909; IRMN, 3; 9 y BCMNa, 1912-13, 108 (miliarios) e HEP9, 441 (indeterminada). Santacris: HEp9, 431; 432; IRMN, 40 y 41 (funerarias); IRMN, 7 y 11 (miliario) e HEp9, 429 (indeterminada). Sofuentes: CIL, II, 2974; 2975; ERZ, 34; 35 36; 37; 39; 40; AE, 1977, 483; 484; IRMN, 61; IRMN, 63 e HEp5, 928 (funerarias); LOSTAL, J.: Los miliarios de la provincia Tarraconense (conventos Tarraconenses, Cesaraugustano y Cartaginense). Zaragoza, 1992, nº. 82; 83; 166 y 176 (miliarios). Sos del Rey Católico: LOSTAL, J.: Arqueología..., pág. 24 y 25 (funerarias). Tafalla: HEp7, 478 y 479 (funerarias). Tudela: HEp9, 442 (indeterminada). Ujué: IRMN, 33 y 34 (votivas). Urbiola: HEp7, 469 (funeraria). Villatuerta: IRMN, 65 y 66 (funerarias). Zábal: IRMN, 82 (funeraria). Zúñiga: HEp3, 269 (funeraria). 